\title{
Modelos de desarrollo, unificación y "desterritorialización"
}

\author{
Ignacio SOTELO PÉREZ \\ Instituto Universitario de Ciencias Ambientales (IUCA) \\ Universidad Complutense de Madrid \\ ignaciosoteloperez@ucm.es
}

Recibido: 10 de julio del 2015

Enviado a evaluar: 12 de julio del 2015

Aceptado: 25 de noviembre del 2015

\section{RESUMEN}

El presente estudio tiene el objetivo de ofrecer una visión general sobre los Modelos de Desarrollo y Organización Territorial desde la perspectiva de las relaciones entre el medio urbano, "rururbano" y rural, en España. Para ello, tras conocer y valorar los enfoque conceptuales y temáticos, se estudia el crecimiento urbano en nuestro país en las últimas décadas, analizando de manera pormenorizada la importancia que ha cobrado y cobra la aplicación legislativa de leyes, planes y normas, tanto en el propio crecimiento urbano como en la demanda de viviendas en las ciudades españolas y, de igual modo, la vinculación de ambas con el precio de las viviendas, relacionándolo con la problemática de la "rururbanización", y del medio rural.

Palabras clave: Modelos de Desarrollo, territorio, Modelos de Organización Territorial, Urbano, Rural.

\section{Development models, unification and "deterritorialization"}

\begin{abstract}
The present study aims to provide an overview of the development models and territorial organization from the perspective of the relationship between the urban environment, "rururban" and rural, in Spain. Therefore, once know and appreciate the conceptual and thematic approach, urban growth is studied in our country in recent decades, analyzing in detail the importance acquired and charges the legislative implementation of laws, plans and policies, both in the own urban growth and housing demand in the Spanish cities and, similarly, linking both to the price of housing, relating to the issue of "rurbanization" and rural.
\end{abstract}

Key words: Development Models, territory, Models of Territorial Organization, Urban, Rural.

1 La presente investigación se enmarca en el Proyecto de Investigación MINECO (2014).CTM2013-41750-P. 


\section{Development models, unification and "deterritorialization"}

\section{RÉSUMÉ}

La présente étude vise à fournir un aperçu des modèles de développement et de l'organisation territoriale $\mathrm{du}$ point de vue de la relation entre l'environnement urbain, "rurbain" et rural, en Espagne. Par conséquent, savoir une fois et apprécier l'approche conceptuelle et thématique, la croissance urbaine est étudiée dans notre pays au cours des dernières décennies, l'analyse en détail l'importance acquise et charge la mise en œuvre législative des lois, des plans et des politiques, à la fois dans le la croissance urbaine propre et la demande de logements dans les villes espagnoles et, de même, reliant à la fois pour le prix du logement, relative à la question de la "rurbanisation" et rural.

Mots clés: Modèles de développement, territoire, Modèles d'organisation territoriale, Urban, rural.

\section{UNA PRIMERA APROXIMACIÓN}

Con la aceleración de la mundialización liberal, el "esquema de consumo y de producción insostenible" incluso se ha reforzado. Las desigualdades han niveles jamás conocidos desde la época de los Faraones. La fortuna de los tres individuos más ricos del mundo es superior a la riqueza acumulada por los habitantes de países más pobres... La mancha antiecológica del primer mundo sobre la biosfera se ha agrandado. Mientras los treinta países más desarrollados representan el $20 \%$ de la población mundial, producen y consumen el $85 \%$ de los productos químicos sintéticos, el $80 \%$ de la energía no renovable, el $40 \%$ del agua potable. Y sus emisiones de gas por habitante, que producen efecto invernadero, comparadas con las de los países del Sur, son diez veces más elevadas... ${ }^{2}$

${ }^{2}$ Durante la primera cumbre de la Tierra, celebrada en Río de Janeiro en 1992, se diagnosticaron los principales males que le acechaban. La señal de alarma se hizo oír entonces: el planeta se recalienta, el agua potable escasea, los bosques desaparecen, decenas de especies vivas están en vías de extinción, la pobreza más absoluta se ceba en más de mil millones de seres humanos...

Los dirigentes del mundo habían admitido que "la causa principal de la degradación continua del medio ambiente mundial se debe a un esquema de consumo y de producción inviable, sobre todo en los países industrializados, extremadamente preocupante en la medida en que agrava la pobreza y los desequilibrios". Se adoptaron dos convenciones decisivas sobre los cambios climáticos y la biodiversidad, junto con un plan -llamado Agenda XXI- para generalizar el desarrollo sostenible.

Este desarrollo se fundamenta en una idea muy simple: el desarrollo es sostenible si las generaciones futuras pueden heredar un medio ambiente que al menos sea igual al que han recibido de las generaciones precedentes. Este desarrollo conlleva la aplicación de tres principios: el principio de precaución que favorece una actuación más preventiva que restauradora; el principio de solidaridad entre las generaciones actuales y futuras, y entre todos los colectivos humanos del planeta; y el principio de participación del conjunto de agentes sociales que poseen mecanismos de decisión. Más de veinte años más tarde, en numerosos campos, la situación no ha mejorado. 
Las más recientes investigaciones siguen insistiendo que a principios del siglo veintiuno el mundo sufre la plaga de una pobreza en aumento y una creciente brecha de desigualdades sociales entre ricos y pobres, conjuntamente con una continua degradación ambiental a escala planetaria (Foro Ambiental Mundial, 2000; PNUMA, $2000,2004)$. Desde principios de los setenta del siglo pasado hasta ahora el medio ambiente ha soportado la agudización y aceleración de las presiones impuestas por un sistema socioeconómico que crece sin conciencia de los límites y que se ha mostrado claramente insostenible, ineficiente y poco equitativo. Un sistema, que en la centuria pasada se ha expandido con un enorme impacto ambiental por la cuadruplicación de la población y por un aumento de la producción económica mundial que se ha multiplicado por dieciocho y que todavía no apunta un cambio de rumbo firme hacia el desarrollo sostenible global. Pero más aun, con la tendencia de una economía cada vez más mundializada, envuelta en la ola de la globalización, aparecen una serie de efectos contrapuestos donde las posibilidades de mejorar el bienestar pueden ser superadas ampliamente por la fractura de la cohesión social, al aumento de las disparidades entre clases sociales y una mayor degradación ecológica del planeta (Sotelo, J.A. 2000b)

Ante esta situación, las estrategias para tender hacia un mundo más seguro y más perdurable pasan por ambiciosos esquemas de cooperación para la reestructuración del "Eco-orden" mundial y la transformación estructural del sistema socioeconómico con enfoques de sostenibilidad. Así pues, se atisban nuevos paradigmas para encarar los nuevos problemas mundiales ambientales, económicos y sociales y hacer frente a un porvenir cada vez más incierto. Entre las nuevas orientaciones que surgen para responder a la crisis, emerge de forma contundente la noción de "sostenibilidad" para configurar nuevos estilos de desarrollo y nuevos esquemas económicos capaces de sustituir a los modelos imperantes que se han mostrado ecológicamente depredadores, socialmente injustos, económicamente inviables, así como claramente vulnerables.

En la actualidad la aldea global ha sido sustituida por el mercado global, dando lugar al tratado tema de la globalización, que, en su actual modalidad neoliberal, tiene carácter excluyente tanto de continentes enteros, los más subdesarrollados, como de sectores cada vez más amplios de los países desarrollados, los que no se adaptan a la permanente renovación tecnológica. Así, podemos plantearnos el siguiente interrogante: ¿por qué los modelos de desarrollo regional? "Es incontestable", afirma Enzensberger, "que el mercado mundial, desde que dejó de ser una visión lejana y se convirtió en realidad global, fabrica cada vez menos ganadores y más perdedores, y eso no en el Tercer Mundo o en el Segundo, sino en los altos centros del capitalismo. Allá son países y continentes enteros los que se ven abandonados y excluidos de los intercambios; aquí son sectores cada vez más grandes de la población los que, en la competencia cada día más grande por las calificaciones, no pueden seguir y caen".

Nadie puede negar, como hemos señalado, que la globalización de la economía reporta muy notables beneficios. Pero no se reparten equitativamente; muy al contrario los países desarrollados cada vez se benefician más que los subdesarrollados, e incluso, en un mismo país, los ricos logran más ganancias que los más pobres. A lo largo de los 
próximos años, la liberalización del comercio reportará entre 212.000 y 510.000 millones de dólares. Sin embargo, los 48 países más subdesarrollados tendrán unas pérdidas anuales de 600 millones en material comerciable, y los del África subsahariana, alcanzarán pérdidas que superarán los 1.200 millones. También ha crecido el producto, el PIB mundial, en términos globales. Sin embargo, el de 44 naciones subdesarrolladas se ha visto seriamente mermado (Tamayo-Acosta, J.J. 1999). ${ }^{3}$

Dar respuesta al interrogante anterior, nos obliga a plantearnos la base conceptual del "subdesarrollo", o por alusión su antónimo "desarrollo". La revisión de la ya abundante literatura especializada conduce a un sinnúmero de definiciones que más que enmarcar el fenómeno lo que hacen es caracterizar o tipificar alguna o algunas de sus manifestaciones, las más de las veces con criterios productivistas ajenos, en general, a la inseparable dimensión social que acompaña a las variables económicas.

A título ilustrativo se han seleccionado algunas aproximaciones de estudiosos que a lo largo del último medio siglo, se han preocupado del tema desde diferentes enfoques ideológicos. Así H. Myint pasa revista a una serie de criterios utilizados para encuadrar el subdesarrollo comenzando por aquellos que se apoyan en el "nivel de renta por habitante" o en su tasa de crecimiento, lo que permite distinguir a los países con rentas y ritmos de crecimiento estancados o declinantes de aquellos otros con mayor dinamismo positivo, los industrializados. El desfase creciente (widening gap) entre ambos grupos de países se constituye en criterio diferencial, válido para una clasificación pero, a nuestro juicio, no para la conceptualización. Por su parte, Marrama analiza algunos ensayos de definición señalando, obviamente, la imprecisión de la que considera "un estado de subdesarrollo allí donde la población es escasa con relación a los recursos naturales disponibles" y valorando en mayor medida la de Viner, que califica como tales "los países que tienen buenas perspectivas potenciales para utilizar más capital o más mano de obra o más recursos naturales disponibles, o estos tres factores con objeto de elevar el nivel de vida de su población actual o, si su renta per cápita ya es alta, sostener una población más numerosa sin que disminuya su nivel de vida". Una más en esta línea es la de Lange, para quien "una economía subdesarrollada es una economía en la que el equipo de capital existente no es suficiente para el pleno

${ }^{3}$ El informe sobre la "Pobreza y el desarrollo en el mundo, en 2008" se centraba en el consumo, abunda en el carácter desigual y excluyente de la globalización. El consumo de bienes y servicios llegará a superar los 24 billones de dólares -seis veces la cifra de 1975- . Globalmente, se ha llegado a un nivel de consumo de alimentos, energía, educación, transporte, comunicación y ocio nunca alcanzado. Ahora bien, de nuevo los niveles de consumo no son ni mucho menos homogéneos, ya que el $20 \%$ de la población mundial realiza el $86 \%$ de los gastos en consumo personal. Desde esta perspectiva, los modelos de desarrollo regional pueden servir al doble reto de aproximar al desarrollo los países subdesarrollados, y encontrar un equilibrio entre globalización y regionalización. En este sentido, deben convertirse en un coadyuvante más, al servicio de los Estados, regiones,..., para superar las diferencias SurNorte, colocar la economía al servicio del desarrollo integral de las personas y los pueblos, denunciar el carácter idolátrico del capital, defender la democratización de los Estados en torno a los valores comunitarios,... (Tamayo-Acosta, J.J. 1999). 
empleo de la fuerza de trabajo disponible, de acuerdo con las técnicas modernas de producción". Pero esta aportación, de notable valor tecnoeconómico, pone el énfasis, al igual que las anteriores, en aspectos cuantitativos -potencial productivo escaso u ocioso-, si bien ya recoge la dimensión social, el paro o el subempleo; sin embargo, limita el fenómeno a una visión estática e impregnada en un cierto matiz "economicista", caracteres ambos que no son los que mejor pueden reflejar la globalidad y "dinamicidad" que el concepto encierra (Paz, M.A de., 1998).

Todos intuimos lo que es el subdesarrollo, pero nadie -acabamos de apuntarlo- lo ha definido con precisión. Está claro que no es sólo una situación económica deprimida, y mucho menos un estadio cultural atrasado, pues dentro de la extensa gama de países incluidos en esta categoría, los hay con culturas milenarias riquísimas, y tampoco parece que todos los países desarrollados puedan darles lecciones en este terreno. Es indudable, en cambio, que la condición de país subdesarrollado lleva consigo una situación de dependencia -política, económica, técnica,...- de otra potencia o de un grupo económico extranjero; supone también, en muchas ocasiones, una falta de participación política de su población en las tareas de gobierno, unas veces porque carece de preparación suficiente y otras porque se le impone una forma de administración sea paternalista o tiránica, que la excluye de ella. El subdesarrollo lleva implícito, desde luego, un nivel de vida extremadamente bajo, un predominio de población rural, un alto grado de analfabetismo, de paro total y paro encubierto; hambre y malnutrición crónicas, por tanto, a veces en grado muy difícil de imaginar, que hacen casi imposible el trabajo intenso y continuado: alta mortalidad infantil, morbilidad muy acusada, mala situación de la mujer -discriminada y considerada inferior- y, en ciertos países -como es de sobra conocido-, una administración incompetente, arbitraria, venal y corrompida.

Las nociones de desarrollo y subdesarrollo corresponden a la óptica occidental, materialista -trátese de capitalismo y comunismo-, que da prioridad a los temas de carácter económico. Desde este punto de vista la diferencia entre unos y otros países es palmaria e innegable. Pero, desde el lado de los países subdesarrollados, ¿podemos decir que comparten los puntos de vista de la población de los países industriales? Indudablemente, no se puede contestar de un modo simplista, pero puede creerse que una buena parte de sus habitantes miran las cosas y la vida con ojos muy distintos. Insistimos una y mil veces en que no es sólo lo económico lo que caracteriza el subdesarrollo de los pueblos y las regiones, aunque quizá, a pesar de sus enormes dificultades, lo económico es lo más fácil de detectar y medir (Sotelo, J.A. 2000 b).

El tema del subdesarrollo es, ante todo y esencialmente, profundamente humano: tres cuartas partes de la humanidad padecen sus consecuencias, y eso se refleja en todos sus aspectos demográficos. Por todos los lados del análisis de las características de la población mundial -tasas de natalidad y mortalidad, índices de crecimiento, estructura por edades, composición profesional de la población, esperanza de vida, condiciones de la mujer, grado de instrucción, renta per cápita,...- encontraremos -con todas las gradaciones y matices que dan las diferencias entre las poblaciones de los países ricos y las poblaciones de los países pobres, entre los países desarrollados y los 
subdesarrollados. Es lógico -lo contrario sería imperdonable- que el interés humano del tema -es la vida de millones de otros hombres lo que está en juego- atraiga no sólo la atención de los científicos, resultando muy doloroso comprobar -aunque nadie que conozca un poco la historia puede sorprenderse- cómo las grandes potencias emplean a estos países como peones, y cabezas de puente, en el trágico juego de la estrategia universal, condicionando su ayuda a que se muevan según su conveniencia.

La humanidad de este fin de siglo está angustiada por las amenazas que siente pesar sobre el medio ambiente. Hacía mucho tiempo que se había denunciado la degradación de determinados medios, pero los problemas han cambiado de escala. La lluvia ácida que dificulta la agricultura y arruina los bosques de Escandinavia, Europa central y el noreste de América del Norte no tiene origen local. Las grandes aglomeraciones humanas y las fábricas del Middel West y de la Europa noroccidental son responsables de emisiones que hacen que el vapor de agua de las nubes deje de ser neutro. El uso de lejías detergentes en las zonas urbanas y el empleo de dosis masivas de abonos en el campo cargan a las aguas de circulación superficial con tantos elementos favorables a la proliferación de la vida que las algas se multiplican y provocan la eutroficación de ríos, lagos y ciertos mares cerrados. Los problemas ecológicos ya no son locales. Exigen actuaciones a escala de la totalidad de las cuencas vertientes de los ríos, de los Estados ribereños de los mares cuyas aguas se remuevan poco, y de todas las naciones que contribuyen a la acidificación de las lluvias en el Antiguo y en el Nuevo Mundo.

La angustia está justificada, pues, por la ampliación de los daños ocasionados al medio ambiente. Lo está también por su carácter acumulativo. Los fertilizantes se infiltran en los mantos freáticos, en donde se concentran, y a los que acaban de volver impropios para el consumo. Las emisiones gaseosas del mundo industrializado modifican de manera sensible la composición de la atmósfera. Las tomas efectuadas en los casquetes glaciares de Groenlandia y de la Antártida ponen de manifiesto el aumento regularmente acelerado, desde los inicios de la revolución industrial, de la cantidad de gas carbónico. Cabe preguntarse si estas transformaciones no van a provocar una conmoción irreversible de los climas por efecto invernadero y destrucción de la capa de ozono.

En el dominio biológico muchas evoluciones ya son irreversibles: el número de especies vegetales o animales desaparecidas, o amenazadas de desaparición, no deja de aumentar. El desarrollo del regadío determina, allí donde las aguas desembocaban en un mar interior, un descenso del nivel de éste, una disminución más drástica aún de su volumen y un crecimiento rápido de su salinidad: las condiciones del medio han sido modificadas tan profundamente en el caso del mar de Aral que la mayoría de las especies no han podido resistir.

Las modificaciones más dramáticas del medio ambiente, al menos las que son percibidas como tales, están vinculadas al contexto nuclear. La idea de que una guerra atómica conduciría a un invierno nuclear, defendida, inicialmente, por los climatólogos soviéticos, ha tenido un amplio eco en todo el mundo. Parece raramente irreversible una contaminación ordinaria: se suele saber que su duración será limitada. En el caso de la radiactividad, la reducción de emisiones no puede ser rápida. Para 
ciertos elementos, los periodos son muy largos. Que los hombres y las mujeres se alarmen es fácilmente comprensible: la extensión en el espacio y en el tiempo de las contaminaciones y el carácter irreversible de algunas de ellas bastan para explicarlo. El eco que han encontrado en la opinión pública ciertos temas, demasiado técnicos para ser comprendidos por la mayor parte de los que hablan de ellos, invita, en todo caso, a ser prudentes. Se hablaría menos de ecología si las ideologías ecológicas no hubieran conocido tanto desarrollo. Es una situación muy diferente de la que se daba todavía no hace mucho. ${ }^{4}$

Mundialización y globalización son procesos de similar estructura pero aplicada a campos categoriales diferentes. El término globalización se aplicaría a la categoría económica; con ella se designaría al proceso de totalización económica e instrumental, llevado a cabo sobre todo a raíz del hundimiento de la Unión Soviética y, con ella, la política bilateral de bloques de la «guerra fría» y la consolidación de un mercado mundial continuo, descolocación de las empresas multinacionales, abaratamiento de $\operatorname{costos}, \ldots$

La mundialización es un proceso literalmente opuesto al de la globalización. Y el único criterio de distinción relativa será éste: el globo es cerrado en sí mismo, mientras que el mundo desborda toda globalización.

Por ello, si la globalización se aplica a las categorías económicas, la mundialización desbordará estas categorías y acogerá a otras diferentes, de carácter social, político, religioso, cultural,...

La mundialización no es una categoría de la ciencia social definida por una construcción analítica. El término "mundialización", en primer lugar, desde una perspectiva económica, supone el desarrollo de intercambios y de la división mundial del trabajo, por un lado, y la globalización financiera, por otro. En segundo lugar, la puesta en cuestión de un Estado-nación que se mostraría impotente ante flujos que no puede controlar $\mathrm{y}$, por último, una mundialización de la comunicación que desembocaría en la formación de una cultura mundial global ante la que parece

\footnotetext{
${ }^{4}$ Podemos señalar que a lo largo de la década pasada, las emisiones de gas carbónico (CO2), la principal causa del calentamiento del planeta, han aumentado un 9\%... Las de Estados Unidos, primer país contaminante del mundo, han crecido, durante el mismo periodo, ¡un 18 ! Más de mil millones de personas continúan sin agua potable, y cerca de tres mil millones (la mitad de la humanidad) consumen agua de ínfima calidad. Por culpa de la ingestión de esa agua contaminada, 30.000 personas mueren diariamente. Los bosques siguen siendo devastados; 17 millones de hectáreas desaparecen cada año, una superficie que es equivalente a cuatro veces la de Suiza. Y como los árboles ya no están ahí para absorber los excedentes de $\mathrm{CO}_{2}$, el efecto invernadero y el calentamiento del planeta se intensifican. Por otro lado, cada año, alrededor de 6.000 especies animales son exterminadas. Una extinción masiva, amenaza a la Tierra como jamás se ha visto desde la desaparición de los dinosaurios: -el $13 \%$ de los pájaros, el $25 \%$ de los mamíferos, el $34 \%$ de los peces.
} 
imposible resistirse a la vista del poder y la capacidad de atracción de los grandes conglomerados mediáticos.

La globalización es un fenómeno, eminentemente, espacial; ocupa un espectro que iría, por un lado, de lo local a lo nacional, por otro, de lo supranacional a lo global. La globalización genera flujos de actividad, interacción y poder extrarregionales y transcontinentales; se trata de interconexiones en campos que van desde lo penal, a lo cultural, pasando por lo financiero y lo medioambiental (aunque para algunos estudiosos no deja de ser un mito; el actual orden económico mundial, considerado en términos históricos, seguiría lejos de estar estrechamente integrado, pues los flujos netos entre las principales economías son hoy notablemente menores a las de hace un siglo).

Estos campos se valoran según su alcance, intensidad, velocidad e impacto del cambio; observando en cada uno de ellos, al separarlos, diferentes formas históricas de globalización, en la intensidad del ritmo de los efectos, y subrayando la importancia de las interacciones sociales y de los flujos interregionales.

Además, a lo largo de las últimas décadas se ha generado un fenómeno que hasta ahora no se había dado: la reorganización de las economías nacionales con base en bloques mundiales de integración; los Estados-nación están en vías de transformación y algunos afirman que están en vías de desaparición ya que las nuevas estructuras de organización económica, de intercambio comercial, social, valorativo, cultural, educativo, medioambiental,..., se generan en bloques conformados por unidades "geoeconómicas mundiales" (sobre las que tienen notable influencia las grandes empresas multinacionales y algunas instituciones como el Banco Mundial, El Fondo Monetario Internacional o la Organización Mundial del Comercio). ${ }^{5}$ (Harvey, D., 2007)

${ }^{5}$ El modelo de crecimiento basado en una mano de obra barata, una moneda infravalorada, exportaciones a ultranza o tipos de interés elevados para atraer a los inversores especulativos internacionales, todo ello en el marco de regímenes políticos autoritarios, empieza a aparecer como menos ejemplar, e incluso más peligroso. Algunos de los países más afectados por estos tifones bursátiles - Indonesia y Malasia - se han visto sacudidos, por añadidura, por desastres ecológicos de una dimensión excepcional. Después de escapar a cualquier control, millares de incendios gigantescos han arrasado los bosques de las islas de Sumatra, Borneo, Java y Célebes, en una extensión de más de 800.000 hectáreas. Inmensas nubes de humos tóxicos, amplias como la mitad de un continente, han cubierto de hollín y sumergido en una semioscuridad a ciudades como Kuala Lumpur, provocando accidentes en serie (un Airbus que se estrella: 234 muertos; una colisión marítima: 29 muertos...). Las dos catástrofes bursátil y medioambiental - están evidentemente ligadas. Porque si, en parte, estos incendios son imputables a la sequía causada por un fenómeno climático cíclico denominado "El Niño", la principal razón del desastre reside en la política de deforestación masiva llevada a cabo desde hace decenios sobre la base de un modelo hiperproductivista, centrado únicamente en la exportación, especulativo y suicida. En nombre de una confusión interesada entre crecimiento y desarrollo, los Estados del Norte y del Sur prosiguen así la destrucción sistemática del medio natural. Los saqueos de todas clases infligidos a los suelos, a las aguas y a la atmósfera, se suceden. Urbanización galopante, deforestación tropical, contaminación de las capas freáticas, 
El capitalismo, mediante las prácticas reproducidas por los hombres y mujeres (trabajadores, inversores, consumidores, empresarios, etc.), construye una especie de segunda piel compuesta de una forma territorial distintiva y formada por infraestructuras de transporte, formas institucionales y regulatorias que le permiten circular libremente y acumularse. Pero como decía Smith, esta segunda piel espacial se organiza y agrupa alrededor de ciertas escalas que temporalmente adquieren una "coherencia estructural" (Harvey, 1985). Esta "coherencia estructural" es alrededor de la cual el capital adquiere por fin una especie de alivio y puede reproducirse salvando y canalizando sus contradicciones. En otras palabras, podríamos decir que es la escala en la que los actores capitalistas pueden relacionarse con menores costes alrededor de un proyecto común. Según Harvey, esta situación se logra normalmente alrededor de una región urbana o ciudad porque esta es la distancia en la que los trabajadores pueden viajar y consumir su sueldo. La "coherencia estructural" se organiza así en el contorno de un mercado laboral local en el que la lucha de clases sobre las condiciones de trabajo, los salarios y las relaciones de consumo y distribución pueden ser negociados. El propio Harvey, sin embargo, mantiene que la "coherencia estructural" es más una tendencia ideal que una situación posible y, admite que "el equilibrio solo puede ser logrado por accidente y entonces tan sólo momentáneamente" (Harvey, 1985, p. 143). También, el mismo Harvey (1985) admite que, con la creciente competición interurbana y la globalización, resulta prácticamente imposible encontrar una "coherencia estructural" alrededor de una región urbana. (Harvey, D., 2007)

Por otro lado, desde la teoría económica dominante, la reorientación exige una amplia visión que ayude a repensar lo económico en clave de sostenibilidad, concebir la economía como un subsistema del ecosistema global y entretejer la "lógica de lo económico" en la "lógica de la biosfera". Es algo más que una simple reforma del modelo económico vigente. Se trata de lograr una profunda transformación de la organización social y de la actividad económica. Y, al mismo tiempo, asumir una visión postmoderna de la Economía para abrir las puertas a un nuevo enfoque científico basado en la ciencia post-normal. Es decir, un enfoque identificado como una evolución y ampliación de la ciencia tradicional para adecuarla a las condiciones del presente, con el reconocimiento de la incertidumbre y la ignorancia, y su empeño en gestionar el bien común" (Funtowicz y Ravetz, 1991). Efectivamente, si los hechos son inciertos, los valores están en discusión, los intereses en juego son altos y las decisiones son urgentes, es preciso reconciliar la razón con la pasión e impulsar cambios de paradigmas en el ámbito de la economía y el desarrollo. (Harvey, D., 2007)

de los mares y de los ríos, recalentamiento del clima, empobrecimiento de la capa de ozono, lluvias ácidas: las poluciones ponen en peligro el porvenir de la humanidad. 


\section{LA REALIDAD FÍSICO-AMBIENTAL}

El problema de la relación del hombre con su medio ambiente natural, del que forman parte el desarrollo y la utilización de los recursos naturales, constituye una tarea tradicional de la geografía. Cuando se le contempla desde diversos puntos de vista, este problema -antes como ahora- atrae marcadamente la atención de los investigadores en todo el mundo. Actualmente está ya desacreditada esa concepción teórica que durante mucho tiempo fue central en la geografía y que se conoce con la denominación de determinismo geográfico, que implicaba la idea del que el medio ambiente había de considerarse como factor determinante del desarrollo social, tesis sugerida originalmente por filósofos e historiadores. En la ex Unión Soviética, el determinismo geográfico, como teoría valida, quedó sometida a una dura crítica, perdiendo su primacía, de una vez para siempre, hace bastante tiempo, en los años 1920-1930. Desde entonces no ha ejercido ninguna influencia importante en la evolución del pensamiento geográfico. No obstante, todos los geógrafos soviéticos reconocen unánimemente la necesidad de considerar y estudiar con profundidad el impacto que ejerce el factor natural sobre el desarrollo, sobre la producción espacial y sobre la distribución de la población. La metodología del determinismo geográficoparticularmente en cuanto se refiere a sus tesis extremas- se rechaza actualmente por la gran mayoría de los geógrafos de los países capitalistas, aunque sin aceptar la argumentación marxista sobre la cuestión. La literatura científica más reciente, en cambio y especialmente la relacionada con el desarrollo de métodos y enfoques nuevos, cuantitativos-y más avanzados, considerados en conjunto-, muestra una tendencia opuesta, la de menospreciar o desconocer la importancia que tiene el medio ambiente natural (AA.VV., 1972).

La acentuación del interés por las relaciones espaciales y los medios para su precisa expresión que aplican el más reciente aparato matemático se traducen en una disminución de la atención prestada a los recursos naturales. La aproximación de la geografía a las ciencias sociales que utilizan con amplitud las matemáticas $-\mathrm{y}$, en particular, modelos estocásticos-para bosquejar regularidades en el comportamiento de las gentes, ha desempeñado indudablemente un cierto papel en la definición del alcance del interés que ofrecen las investigaciones más recientes. Parece que, al ocuparse en sus cálculos y modelos de un espacio geométrico abstracto, libre de cualquier contenido geográfico - o físico-geográfico- concreto, los llamados geógrafos "cuantificadores" se dejan llevar a conclusiones extremas. No sería en modo alguno justo sugerir la idea de que los investigadores rechacen los métodos de modelado matemático ni que se opongan, en sentido amplio, a la investigación que busca leyes, esto es, que se resistan a los enfoques más avanzados de la moderna ciencia geográfica. Creemos, no obstante, que tales medios instrumentales de conocimiento, tan poderosos como son, deben ponerse al servicio de los problemas geográficos más importantes. Con respecto a los recursos naturales, sería útil desarrollar métodos que permitan analizar tales recursos como factores configuradotes de entidades regionales complejas, incluyendo su valor en los correspondientes modelos, junto con las demás variables. Deberían encontrarse 
métodos que permitieran tomar en consideración rasgos ambientales naturales concretos, a modo de índices espaciales, dentro del radio de acción de los modelos matemáticos. Todo lo que llevamos dicho se refiere, pues, a las cuestiones de regionalización económica, para cuya solución se están utilizando hoy ampliamente métodos matemáticos, siendo ejemplo de ello el trabajo que lleva a cabo nuestra comisión (AA.VV., 1972) Desgraciadamente, en este terreno se otorga prioridad, considerándose más urgente, a la elaboración de técnicas de análisis más refinadas, en lugar de atender a la esencia económico-geográfica del problema en cuestión. Como resultado de tal perspectiva, la labor implica la consideración como variables de numerosos factores auxiliares. Al propio tiempo, se deja fuera de los límites del modelo el factor "recurso natural" -tan importante para el desarrollo económico y, ante todo, para la producción -, que hasta ahora no ha encontrado expresión cuantitativa. $^{6}$ En el inicio del siglo XXI, el estado del medio ambiente continúa empeorando a nivel mundial porque los problemas ambientales siguen profundamente arraigados en la trama socioeconómica mundial. Aunque algunos países han podido poner freno a la contaminación y disminuir el ritmo de degradación de recursos, en general, la situación tiende a empeorar (AA.VV., 1972) Según informes de Naciones Unidas, la situación general sigue siendo preocupante, según los datos presentados a continuación (CDS, 1997, PNUMA,1997, 2000).

Las condiciones de los hábitat naturales y de los ecosistemas frágiles, sobretodo, los ecosistemas de montaña, siguen empeorando en todas las regiones del mundo, lo que tiene como consecuencia la disminución de la biodiversidad biológica. A escala mundial, los recursos renovables (agua, tierra, bosques, peces) se están utilizando a un ritmo mayor que el de su renovación, con evidentes síntomas de insostenibilidad. De la misma manera puedes decirse que el uso ineficiente de materiales y energía conlleva el aumento de los niveles de contaminación, que están sobrepasando la capacidad de absorción natural del medio ambiente mundial. (Smith, N. 2012).

\footnotetext{
${ }^{6}$ Hay dos aspectos del problema que tratamos en el presente trabajo que quisiera subrayar. En primer lugar, que el problema está indudablemente relacionado con las peculiaridades geografía como ciencia que estudia, no conexiones espaciales (topológicas) abstractas, sino leyes y formas de desarrollo de complejos espaciales de fenómenos naturales y sociales en su mutua interacción. En segundo lugar, que el problema presenta un gran valor práctico, dado que el desarrollo de los recursos naturales constituye el factor más importante en la formación de la estructura económica espacial en un cierto número de países. En tal aspecto, las investigaciones geográficas pueden ofrecer una significación particular para los países nuevos en vías de desarrollo, paral los que los problemas más agudos que se les plantean son los relativos al desarrollo de los recursos naturales y al rendimiento de una política eficaz de desarrollo regional. Sin embargo, la experiencia obtenida por los geógrafos soviéticos y por algunos otros extranjeros demuestra que los factores naturales pueden tener también gran importancia en la formación de la estructura económica espacial y del sistema regional incluso en los países altamente desarrollados.
} 
Las emisiones de muchos contaminantes, en particular, sustancias tóxicas, los gases de efecto invernadero y el volumen de los desechos continúan aumentando, y se ha avanzado escasamente en la gestión ecológicamente racional de los desechos radiactivos, los desechos peligrosos y el control del movimiento transfronterizo de estos desechos. En estos dos sentidos apuntados, los síntomas de degradación y desequilibrios del medio natural y social son bien significativos en el contexto del cambio global.

\section{CONSECUENCIAS DEL DESARROLLO HUMANO}

Como señala Harvey, el impulso de la acumulación de capital es el motivo central en el relato de la transformación histórica y geográfica del mundo occidental en tiempos recientes, y parece destinado a engullir a todo el mundo en el siglo XXI. Durante los pasados 300 años ha sido la fuerza fundamental en la remodelación de la política, economía y el medio ambiente mundiales. Este proceso de usar el dinero para hacer más dinero no es el único en funcionamiento, por supuesto, pero resulta difícil encontrarles sentido a los cambios sociales de estos pasados trescientos años, sin observarlo muy de cerca (Smith, N. 2012).

El materialismo histórico contemporáneo ha intentado aislar los procesos fundamentales de acumulación de capital que generan el cambio social, económico y político y, mediante un estudio cuidadoso de los mismos, entender los porqués y los cómo de tales cambios. Presta atención especialmente a los procesos, más que a cosas y acontecimientos. Se parece un poco a ver un alfarero utilizando una rueda: el proceso puede ser fácil de describir, pero los resultados pueden ser infinitamente variados en forma y tamaño. Sin embargo, decir que se está dando un proceso sencillo no quiere decir que todo acabe pareciendo exactamente lo mismo, que los acontecimientos sean fácilmente predecibles o que todo se pueda explicar haciendo referencia a él. El impulso de acumulación de capital ha ayudado a crear ciudades tan diversas como Los Angeles, Edmonton, Atlanta y Boston, y transformado casi más allá de todo reconocimiento (aunque de maneras muy diferentes) ciudades antiguas como Atenas, Roma, París y Londres. Ha conducido igualmente a una búsqueda incansable de nuevas formas de trasladarse, nuevos lugares que colonizar; una infinita variedad de estrategias que reflejan un ilimitado ingenio humano para encontrar nuevas formas de obtener beneficio. El capitalismo, en resumen, siempre ha prosperado con la producción de diferencia ${ }^{7}$ (Harvey, D., 2007).

\footnotetext{
${ }^{7}$ Las normas que rigen el juego de la acumulación de capital son, sin embargo, relativamente sencillas y conocibles. El capitalismo trata siempre del crecimiento, sin importar las consecuencias ecológicas, sociológicas o geopolíticas (de hecho, definimos las crisis como bajo crecimiento); siempre se relaciona con cambios tecnológicos y de estilo de vida (el progreso es inevitable); y siempre es conflictivo (abundan las luchas de clase y de otro tipo). Ante todo, el capitalismo genera mucha inseguridad: siempre es inestable y tendente a las crisis. La historia de la formación y resolución de las crisis capitalistas es, sostengo,
} 
Además, algunos teóricos posmodernos sostenían que el mundo no era conocible porque no había manera segura de establecer la verdad, y que meramente fingir que conocemos una versión de "verdad universal" o, peor aún, aferrarnos a unas de esas versiones, sienta las bases para los holocaustos y otros desastres sociales. Lo mejor que podemos desear, decían, es dejar que las cosas florezcan a sus modos múltiples y diferentes, buscar alianzas cuando sea posible, pero evitar siempre hacer proselitismo sobre supuestas soluciones universales o fingir que existen verdades generales y conocibles. Este tipo de pensamiento penetró en la arquitectura, las artes, la cultura popular, los nuevos estilos de vida y las políticas de género.

Ciertamente, esto aporta muchos elementos refrescantes, en especial el hincapié en la heterogeneidad, la diversidad, los múltiples intereses superpuestos de género, clase, ecología y demás. Pero yo no veo por qué el tipo de heterogeneidad que el posmodernismo celebra sea de manera alguna incongruente con el pensamiento de que el mundo es conocible mediante la apreciación, pongamos, de los procesos de acumulación de capital, que no solo prosperan con la diferencia y la heterogeneidad sociales, sino que las producen activamente AA.VV. (1972).

Dado que este cambio de sensibilidad cultural se produjo paralelamente a cambios muy radicales en la organización del capitalismo tras la crisis de 1973-1975, parecía incluso verosímil sostener que el posmodernismo era en sí producto del proceso de acumulación de capital. Después de 1973, por ejemplo, vemos que la política de la clase trabajadora pasó a la defensiva a medida que crecían el desempleo y la inseguridad en el trabajo, disminuía el crecimiento económico, se estancaban los salarios reales y se imponían todo tipo de sustitutos a la verdadera actividad productiva para compensar una oleada tras otra de desindustrialización. La obsesión por las fusiones, las orgías crediticias y todos los demás excesos de la década de 1980, que ahora estamos pagando, eran la única actividad vital en un momento de desmantelamiento gradual del Estado del bienestar y de ascenso del laissez-faire y de políticas muy conservadoras. Además, la crisis de 1973 puso en movimiento una frenética búsqueda de nuevos productos, nuevas tecnologías, nuevos estilos de vida y nuevos dispositivos culturales que pudieran dar un beneficio. $Y$ esos años contemplaron también una reorganización radical de las relaciones de poder

fundamental para entender nuestra historia. Entender las reglas de la acumulación de capital nos ayuda a comprender por qué nuestra historia y nuestra geografía adoptan las formas que adoptan. En The Condition of Postmodernity se intenta aplicar estas ideas para explicar los cambios recientes experimentados en la economía y la cultura del mundo capitalista avanzado. Señalé que el pensamiento posmoderno tendía a negar todo los sistemático o general en la historia y mezclar imágenes e ideas como si los criterios de coherencia no importaran: hacía hincapié en la separación, la fragmentación, lo efímero, la diferencia y lo que ahora se denomina a menudo la "otredad" (término extraño que se usa principalmente para indicar que no tengo derecho a hablar en nombre de, o quizá ni siquiera sobre otros, o que cuando hablo sobre ellos los "interpreto" a mi propia imagen). 
internacionales, porque Europa y Japón se enfrentaron al poder dominante de Estados Unidos en los mercados económicos y financieros. ${ }^{8}$ (Smith, N. 2012).

Por otra parte, señalar que en los últimos años se ha reforzado la idea de que la crisis ecológica ha alcanzado la dimensión planetaria a través de fenómenos que han dado lugar a un cambio global. Reconociendo que en los últimos decenios la presión del crecimiento de la población y el aumento de la pobreza de los países subdesarrollados ha erosionado gran parte de la base de los recursos naturales del mundo, se puede confirmar que el uso intensivo de materiales y energía promovido por las modalidades de producción y consumo de las economías industriales modernas son los factores que han venido provocando una mayor presión ambiental. Y con ello aún se toma mayor conciencia de la insostenibilidad de los modelos de desarrollo actuales. Somos cada vez más conscientes que la humanidad- unos pocos por "demasiada riqueza" y otros muchos por "demasiada pobreza"- están consumiendo los recursos de la naturaleza y contaminando la biosfera a escalas y velocidades que ponen en peligro la convivencia mundial, el equilibrio dinámico y la capacidad de sustentación del ecosistema planetario. ${ }^{9}$

${ }^{8}$ Este cambio general del viejo modelo de acumulación de capital a uno nuevo, se le denomina el cambio del fordismo (la cadena de montaje de producción en masa, la organización política de masas y las intervenciones del Estado del bienestar) a la acumulación flexible (la búsqueda de mercados especializados, la descentralización unida a la dispersión espacial de la producción, la retirada del Estado- nación de las políticas de intervención unida a la liberalización y la privatización). Así, pues, podemos afirmar que el capitalismo, al experimentar esta transición, había producido las condiciones para el ascenso de los modos de pensar y funcionar posmodernos. El ecosistema Tierra a lo largo de la evolución se ha enfrentado varias veces a un fenómeno de cambio ambiental global. Pero, ahora la alteración del sistema ambiental tiene un origen humano y, sobre todo, es el alcance y la velocidad de los acontecimientos lo que confiere una nueva dimensión al proceso de trasformación biológica, climatológica o geológica que empezamos a percibir actualmente. Por el contrario, este cambio biofísico se está produciendo a través de un fenómeno de cambio económico y social global que no tiene precedentes históricos. La dinámica del sistema socioeconómico está alentada por un proceso expansivo de aumento de población, conjuntamente con otros procesos de globalización económica y tecnológica.

${ }^{9}$ Existen evidencias palpables y claros síntomas del deterioro y desequilibrios de los sistemas ambientales y de los sistemas humanos, que nos permite tomar conciencia de una crisis planetaria. Los fenómenos críticos de alcance global, no solamente se refieren a la alteración de ciertos procesos básicos del equilibrio terrestre (cambio climático, agujero de la capa de ozono, pérdida de biodiversidad, etc.), incluyéndose ahora la inesperada perturbación de los grandes ciclos biogeoquímicos que regulan el sistema planetario, sino que también se deben incluir ciertos fenómenos básicos para el equilibrio dinámico de la economía y de la sociedad mundial, como son el conjunto de desigualdades mínimas y la distribución equitativa de los beneficios del crecimiento económico en el contexto internacional y nacional. A nivel mundial, la desigual distribución de los ingresos en el interior de los países supone que más de 1500 millones de personas en el decenio de los noventa no participaran en el reparto del aumento de la "tarta" (PNUD,1998), sufriendo una disminución de la renta per cápita. Asimismo, hay que destacar la tensa brecha Norte-Sur y la pobreza mundial que también, como fenómeno 
Es en este ámbito en el que cobran relativa importancia conceptos ya clásicos como la "gentrificación". Este término expresa el obvio carácter clasista del proceso, y por ese motivo, si bien el que se muda al barrio puede no ser técnicamente un "miembro de la alta burguesía" (gentry) sino un profesional blanco de clase media, el término es de lo más razonable. Tal como hoy sabemos a partir de una gran cantidad de documentos, el término "gentrificación" fue acuñado en Londres en el año 1964 por la eminente socióloga Ruth Glass. He aquí su clásica definición: "Uno a uno, gran parte de los barrios de la clase trabajadora de Londres se han visto invadidos por las clases medias- altas y bajas. (Smith, N. 2012).

Las degradadas y modestas calles franqueadas por antiguas caballerizas, convertidas, convertidas en viviendas, y las casitas-dos habitaciones arriba y dos abajo- fueron sustituidas cuando expiraron los contratos de arrendamientos por elegantes y costosas residencias. Grandes casas de la época victoriana que se habían degradado en el periodo anterior o más recientemente- al ser utilizadas como albergues $u$ ocupadas por varias familias- han subido nuevamente de categoría (...) Cuando este proceso de "gentrificación" comienza en un barrio, avanza rápidamente hasta que todos o la mayoría de los ocupantes iniciales, miembros de la clase trabajadora, son desplazados, así se modifica el carácter social del barrio (Glass, 1964; XVIII) ${ }^{10}$

global, alcanza a todos; en primer lugar, obviamente, a los propios pobres, pero también a los ricos. Porque, cuando un fenómeno es global, sea ambiental o social, al final afecta a todo el mundo, independientemente de dónde y cómo se haya producido.

${ }^{10}$ Sin embargo, el prestigio de la "gentrificación" era demasiado importante como para impedir que la palabra y su significado se propagaran, a veces de modo asombroso. Por ejemplo, en un informe periodístico acerca de los nuevos indicios paleontológicos en relación con el avance de la agricultura doméstica en Europa hace aproximadamente 9000 años, a expensas de los cazadores-recolectores, se brindaba la siguiente explicación, incluida una cita de un académico británico: "Los cazadores -recolectores que se interpusieron en el camino de este avance sufrieron un proceso de gentrificación- o incluso yuppificación- desde el Este" (Stevens, 1991). Probablemente, la siguiente concatenación crítica de toda nueva historia con la experiencia del gentrificante "East village" de Nueva Cork, resulte aun más asombrosa: Cuando "la historia" supera una parte del pasado reciente siempre supone un alivio - una de las cosas que hace la historia (...) es fumigar la experiencia, haciéndola segura y estéril (...) La experiencia sufre una gentrificación eterna; el pasado, todas sus partes desagradables y excitantes y peligrosas, incomodas y reales, se transforman gradualmente en el East Village. ("Notas y comentario", 1984: 39; véase también Lowenthal, 1986:XXV). El poder simbólico de la "gentrificación" implica que estas generalizaciones de su significado sean, sin duda, inevitables, pero incluso cuando estos sucede desde una perpectiva crítica tienen tanto aspectos favorables como negativos. Tal como sucede con todas las metáforas, el término "gentrificación" puede ser utilizado para brindar una entonación crítica (o no tan crítica) a experiencias y hechos radicalmente diferentes. Pero, llegado el momento, la propia "gentrificación" viene afectada por su apropiación metafórica, hasta el punto en el que la "gentrificación" se generaliza para representar la "eterna" inevitabilidad del renacimiento moderno y de la renovación del pasado, dejando a oscuras las profundamente polémicas 
La intención crítica del término acuñado por Glass es inequívoca, y fue ampliamente comprendida a medida que la palabra empezaba a hacerse popular. Precisamente, fue esta intención crítica lo que los promotores inmobiliarios, los terratenientes y el Consejo de bienes Inmobiliarios han sido incapaces de mitigar, y esto a pesar de la vigorosa promoción de eufemismos que parecían más neutrales en relación con las líneas de clase y raza de la "gentrificación". Con el anuncio de 1985, el Consejo de bienes Inmuebles, que había fracasado en su intento de acabar con la palabra, trataba ahora de redefinirla, darle una connotación nueva y menos sensible, gentrificar la palabra misma. Y no estaban solos. Sólo dos meses antes de la publicación del anuncio del Consejo de Bienes Inmuebles, el senador neoyorquino Alfonso D'Amato, un exuberante defensor y benefactor del capital inmobiliario, que daba entonces sus primeros pasos en un gran proyecto de gentrificación en Harlem, respondió con ira a los manifestantes afirmando que la "gentrificación" no significaba ni más ni menos que "viviendas para los trabadores" (Smith, N., 2012)

Sin embargo, desde la década de 1960 hasta los años noventa del pasado siglo, a medida que crecía la crítica académica y política a la urbanización resdidencial de los barrios periféricos, la gentrificación a pasado a expresarse, en muchas personas, con un optimismo extraordinario, fundado o no, con respecto al futuro de la ciudad ${ }^{11}$. A pesar de las revueltas urbanas y de los movimientos sociales de los años sesenta, la gentrificación ha representado una novedad completamente imprevisible en el pasaje

políticas de clase y raza de la "gentrificación" contemporánea. La oposición a la "gentrificación", aquí y ahora, debe ser rápidamente desechada, tal y como el cazadorrecolector rechazó el "progreso".

11 Cuando se destaca la ubicuidad de la gentrificación de finales del siglo xx, y su conexión directa con los procesos fundamentales de la reestructuración económica, política y geográfica, pienso que es importante matizar este panorama con el contexto. Sería insensato pensar que la parcial tranformación geográfica del foco de la inversión urbana supone su contrario, el final de los suburbios. No cabe duda de que suburbanización y la gentrificación están interconectadas. La dramática suburbanización del paisaje urbano en el último siglo, o antes, ha provisto de un locus geográfico alternativo para la acumulación de capital y, de ese modo, ha fomentado una relativa desinversión en el centro- más intensa en Estados Unidos. Pero, en realidad, no hay señales que indiquen que el auge de la gentrificación haya hecho disminuir la suburbanización contemporánea. Todo lo contrario. Las mismas fuerzas de la reestructuración urbana que han dado paso a los nuevos paisajes de la gentrificación en los centros urbanos han transformado también los suburbios. La recentralización de las funciones administrativas, comerciales, recreativas y turísticas han venido acompañada de una paralela descentralización que han producido suburbios mucho más integrados funcionalmente con sus propios centros más o menos urbanos-las denominadas "edge cities" (Garreau,1991). Si a partir de la década de 1970, en la mayoría de los lugares, el desarrollo suburbano ha sido más volátil, como respuesta a los ciclos de expansión y contracción económica, la suburbanización todavía representa una fuerza más poderosa que la gentrificación en el modelado geográfico de la metrópolis. 
urbano, un nuevo conjunto de procesos urbanos que ha adquirido inmediatamente una fuerte importancia simbólica.

La contienda en torno a la gentrificación representa una lucha no sólo por los nuevos y viejos espacios urbanos sino también por el poder político y simbólico en la determinación del futuro urbano. La contienda ha sido tan intensa en los periódicos como en las calles, y por cada defensa de la gentrificación, como la realizada por el Consejo de Bienes Inmobiliarios de Nueva Cork, se ha producido un ataque contra los desplazamientos provocados por la misma, por el aumento de los alquileres y por la tranformación de los barrios (Smith, N. 2012)

\section{TERRITORIO, SOSTENIBILIDAD Y MEDIO AMBIENTE, EN ESPAÑA: ESPACIOS Y TERRITORIOS URBANOS}

Actualmente, tal y como afirman algunos autores ${ }^{12}$, el sistema legal resulta altamente contradictorio, ya que objetivo principal es hacer más eficiente el proceso inmobiliario - principalmente el de construcción de obra nueva, ya que en España el negocio inmobiliario ha derivado de explotar la multiplicación que se opera en el valor de los terrenos al hacerlos urbanizables buscando así los beneficios derivadas de la reclasificación y recalificación de los terrenos, con lo que la promoción inmobiliaria ha favorecido mucho más la nueva construcción que la conservación del patrimonio construido (Fariña y Naredo, 2010)-; por ello, la legislación concibe la ciudad como un territorio vacío en el que destacan exclusivamente el ámbito arquitectónico-patrimonial y el ámbito natural, a través de los cuales se asociación los distintos aprovechamientos -fundamentalmente los vinculados a los usos residenciales- que, como afirma el profesor Feria Toribio (2010) se justifican no tanto por su necesidad real como por el bajo impacto de su presencia. Y es que esta forma de valoración se ve reforzada por la legislación que, a pesar de intentar de erradicar la especulación, tiende a olvidar el propio funcionamiento del sistema y de las empresas inmobiliarias, que trasladan los costes y los beneficios esperados no obtenidos al precio final de la vivienda, con lo que las leyes y los planes no atienden finalmente a las necesidades reales de la población sino a las de los empresarios del subsector de la vivienda, lo que incide muy negativamente sobre el propio medioambiente, en general, y en la sobreexplotación de los recursos hídricos, en particular. Y es que la legislación en materia de urbanismo estatal y autonómica es tan "optimista" que contempla el cambio del insostenible paradigma que representa, camuflando su crónica inutilidad mediante cambios nominales, prólogos elocuentes y

\footnotetext{
${ }^{12}$ Roca, J. (2003). “La delimitación de la ciudad, ¿una cuestión posible?”. Ciudad y Territorio. Estudios Territoriales, XXXV.pp. 17-36

Embid Irujo, A. (2010) La política de aguas y su marco jurídico. Fundación nueva cultura del agua. Sevilla.
} 
visionarios, que ya no sirven para atajar el problema real de la ciudad, es decir, el control del suelo (Gómez Ordoñez et alii, 2004). Todo ello con el fin de obtener un equilibrio entre cantidad -cada vez se emplea más suelo- y aprovechamiento -cada vez más bajo- para conseguir una ciudad más abierta, más extensa, más lejana, más costosa, y más difícil de mantener.

Como señaló el profesor Joaquín Bosque Maurel (2000), a pesar de que son más de tres décadas las que llevamos aplicando políticas ambientales en la Unión Europea, menos sin duda en España, la calidad general del medio ambiente no ha aumentado, al menos de manera perceptible. Se pone de esta forma de manifiesto que las políticas ambientales, "per se", no son capaces de proporcionar el tan teóricamente ansiado "desarrollo sostenible", fijado ya como objetivo básico en el Tratado de Amsterdam.

El deterioro de los espacios naturales, en la presente obra se tratan los españoles, sólo puede acarrear pérdidas materiales y de bienestar, en las generaciones presentes $\mathrm{y}$ en las futuras. No debemos olvidarnos que una vez traspasados ciertos umbrales críticos y rota la capacidad de regeneración del medio, ni la actividad humana ni, probablemente, la vida misma serían posibles. Tampoco podemos olvidarnos que la presencia del hombre en la Tierra y su propia subsistencia ha implicado siempre el uso y la transformación -en ocasiones hasta la destrucción- del propio espacio terrestre (Bosque Maurel, J., 2000). ${ }^{13}$

${ }^{13}$ Para el profesor Vázquez Espí (1998), el desaforado consumo de recursos no presenta las mismas características en unos lugares u otros del planeta. Un hecho comúnmente aceptado es que los países "desarrollados", con un $20 \%$ de la población, consumen un $80 \%$ de los recursos Imaginemos una humanidad dividida en dos clases homogéneas, "ricos" y "pobres", e intentemos percibir cómo se reparten 100 unidades de recursos entre 100 personas. A cada uno de los veinte "ricos" le tocan 4 unidades; mientras tanto los 80 pobres se conformarán cada uno con 1/4 de unidad de recurso. Tenemos una primera conclusión: los "pobres" se comportan de forma mucho menos insostenible que los "ricos" pues a fin de cuentas hacen lo mismo (nacer, crecer, reproducirse y morir) consumiendo quince veces menos recursos que sus vecinos. De los veinte ricos, dieciseis viven en ciudades en el sentido moderno del término y suponiendo que se reparten los recursos equitativamente con sus 4 colegas rurales, se quedan en su ciudad "rica" con 64 unidades de recursos. Entre los 80 "pobres", solo 24 viven en ciudades "modernas" y suponiendo de nuevo un reparto equitativo con sus colegas del campo, se quedan en su ciudad "pobre" con 6 unidades de recursos. En total, por tanto, el sistema urbano moderno alberga 40 personas entre "ricos" y "pobres" y consume 70 unidades de recurso, es decir, casi 2 unidades per capita. El mundo rural, con sus campos, pueblos y aldeas, alberga a 60 personas que utilizan para su subsistencia solo 30 unidades de recursos, es decir, sólo media unidad de recurso por campesino. De este modo, la conclusión es que nuestro moderno y aparatoso sistema de ciudades resulta casi 4 veces más despilfarrador, contaminante e insostenible que el mundo rural y agrícola. Esta es una estimación muy, pero que muy prudente, puesto que en realidad, el reparto de los recursos dista mucho de ser homogéneo: tanto entre "ricos" como entre "pobres", las ciudades se quedan con mayor parte del pastel que el campo; pero además una parte de los recursos que el campo gasta no son en realidad para la subsistencia de los campesinos que allí viven, sino para la futura alimentación de los habitantes de las ciudades. Si se consiguiera transformar el sistema urbano de manera 
Los modelos de "desarrollo urbano", también los que se enmarcan en el contexto de las denominadas políticas medioambientales, reflejan con notable nitidez el que la ciudad del siglo XXI (ciudad cableada, ciudad de la paz, ciudad de la ciencia,...), deberá ser la expresión de la historia y de la cultura urbana que se hayan consolidado a lo largo del tiempo. El malogrado arquitecto Saenz de Oiza definió alguna vez la ciudad como el espacio geográfico que una persona humana puede recorrer entre el amanecer y el ocaso. Una sugerente definición, que desde luego tiene más que ver con la ciudad moderna, que con ninguna otra. Una definición que en todo caso revela a la vez como puede sobrepasarse el límite energético al transporte sostenible y como el transporte constituye una de las causas principales de la actual insostenibilidad urbana: para ciertos privilegiados existe la ciudad Madrid/Barcelona o la ciudad París/Londres gracias al voraz consumo de energías fósiles. En España y en el resto de los países comunitarios, el crecimiento económico, a pesar de ir paralelo a un cierto proceso de "ecoeficiencia", exige cada vez más consumo de recursos naturales, amén de generar un mayor número de agentes contaminantes y de residuos incluyendo a los tóxicos y peligrosos-. Sin duda, los avances en la integración del medio ambiente en la toma de decisiones y en las políticas de tipo sectorial, en los momentos presentes, es un fenómeno real, con avances calificables, cuando menos, de lentos ¿Es "sostenible" la ciudad de Nueva York? Depende. Si el actual orden internacional se sostiene, la ciudad de Nueva York podrá seguir consumiendo fantásticas cantidades de recursos a la vez que, a través de una economía internacionalizada, la contaminación producida por su funcionamiento se manifestará muy lejos de la isla de Manhattan. Vista así, es una ciudad sostenible por la simple razón de tener el poder político necesario para sostenerse.

Pero el concepto de sostenibilidad que aquí nos interesa $-\mathrm{y}$ ya lo hemos comentado en parágrafos anteriores- es el que José Manuel Naredo (1996) ha denominado sostenibilidad fuerte: ¿puede extenderse el funcionamiento de Nueva York a toda la botella herméticamente cerrada, es decir, al planeta en su conjunto? Les ahorraré los cálculos: si en todas las ciudades del planeta se adoptara la fisiología de Nueva York u otras ciudades semejantes, las reservas de combustible tardarían en agotarse unos cincuenta años. Sin embargo no estaríamos allí para verlo pues, mucho antes, la atmósfera se habría vuelto altamente contaminante para los animales superiores. Por tanto, ninguna de las denominadas "ciudades globales" sirve como modelo sostenible para el conjunto de las ciudades del planeta. La sostenibilidad fuerte presupone, como ven, la equidad entre los miembros de la especie y, en consecuencia, no sólo asegura la viabilidad ecológica y física, también sienta las bases, al menos las necesarias, para una convivencia pacífica y justa con nuestros semejantes.

que redujera su consumo al nivel del medio rural, el consumo global de recursos de la humanidad podría disminuirse como poco a la mitad. 
Para que las "ciudades globales" se sostengan sin destruir el medio físico y biológico que las alberga, la condición necesaria (aunque quizás no suficiente) es muy clara y precisa: las "ciudades globales" tendrán que impedir, incluso por la fuerza, que el resto del mundo alcance sus mismas cotas de consumo y disfrute de recursos (evitando la consiguiente producción de contaminación). Hay datos recientes que confirman esta desalentadora conjetura. Así, mucho se ha alardeado acerca de que el consumo per capita de energía en todo el mundo ha permanecido casi estable en la última década, queriéndose indicar con ello que el sistema global comenzaba a corregir sus disfunciones. (Valenzuela, L.M. 2011).

Plantear un modelo sostenible sobre el papel es tarea extraordinariamente simple: basta con dos condiciones que deben cumplirse simultáneamente: que todos nuestros procesos, simples o complejos, funcionen como "norias", cerrando los ciclos de materiales, y que tales "norias" sean movidas por la energía libre de origen solar (la propia radiación solar, el viento, etc.). La simultaneidad de ambas condiciones merece subrayarse: no basta con que a los enchufes de nuestras casas nos llegue electricidad de origen solar, en vez de térmico o nuclear: si seguimos con la misma forma de vida los ciclos de materiales que utilizamos seguirán sin cerrarse, y contaminarán el ambiente en cuanto su concentración supere ciertos umbrales. En este punto se reconoce a los grupos ecologistas más sensatos cuando simultáneamente solicitan energía solar y reciclaje. También se reconoce la habilidad empresarial de las divisiones de "energías renovables" de las grandes multinacionales petrolíferas: planeando la construcción de grandes centrales eólicas o solares, responden bien a los intereses de la empresa: seguir con el negocio a la vez que mejoran su imagen pública. Por supuesto es preferible una megacentral eólica a una térmica o nuclear, pero de no cambiar nada más, seguiremos viviendo de forma globalmente insostenible.

Por tanto, para construir una "ciudad sostenible" en el mundo real lo que se impone es transformar radicalmente nuestras insostenibles ciudades modernas, y nuestra forma de vivirlas. No se trata de construir otras nuevas. Muy al contrario: en conurbaciones como Madrid, con viviendas vacías suficientes como para albergar holgadamente un millón más de personas, resulta urgente parar de construir. Tenemos que reciclar nuestras ciudades. Debe quedar claro que la simple enunciación teórica del problema y de su solución no basta: desde mediados del siglo XIX (quizás antes) lo que yo denominaría "movimiento ecologista" (nutrido por personas de muy distinto origen y especialidad) ha puesto sobre la mesa los instrumentos técnicos y analíticos necesarios, pero una y otra vez estos han caído en saco roto. Debemos concluir que otro genero de fuerzas operan en el fenómeno urbano y que, sin contar con ellas, nada podrá hacerse. ${ }^{14}$ (Valenzuela, L.M. 2011).

\footnotetext{
${ }^{14}$ Podemos entender mejor lo expuesto si observamos el pasado: hubo ciudades insostenibles y sus vacías y románticas ruinas nos han permitido vislumbrar algo de su antiguo esplendor. También las hubo sostenibles, y muchas de ellas dan hoy cuerpo a los llamados "cascos históricos" de nuestras conurbaciones. La ciudad del pasado fue muchas cosas a la vez. Desde luego fue y es uno de los medios físicos utilizados por el ecosistema humano para controlar y
} 
¿Por qué la ciudad creada por los habitantes para alojarse comenzó a transformarse en Europa -y de forma concreta en España- en la ciudad propuesta para alojarlos? De entre los varios factores que pueden invocarse, el colonialismo que siguió al "descubrimiento" de América podría tener especial relevancia. Imagínense a los conquistadores intentando convertirse en tales: intentando dominar un territorio ya primorosamente ocupado por el indígena tanto en lo rural como en lo urbano: por pura necesidad militar, el conquistador descubre, de nuevo, que es posible proponer e imponer una ciudad a una población sin contar con ella, dando lugar a las cuadrículas de la ciudad colonial, desprovista de esas formas orgánicas que podemos apreciar en las ciudades europeas del medievo. Nada más natural que aplicar esos mismos principios en la propia metrópolis. En un sentido preciso, la ciudad moderna europea, extendiéndose alrededor del villorrio medieval, se ha autocolonizado así misma, produciendo el mismo efecto que en la ciudad ultramarina: la pérdida de la condición de verdaderos ciudadanos de sus habitantes. Con la conquista aparece la separación entre colonizador y colonizado, que será reproducida en la metrópoli, entre administrador y administrado. Con ella comienza otra vez el transporte horizontal a larga distancia y la explotación de otros territorios. En el campo colonial sólo vive el indígena, así que nada más espontáneo que elevar de categoría a la ciudad habitada por el conquistador y su corte, degradando así lo rural, como territorio salvaje e incivilizado. Con el tiempo, la lógica del colonialismo se universalizó comenzando a ser percibida como un bien en sí mismo. ${ }^{15}$ (Valenzuela, L.M. 2011).

mantener su estructura. Tal y como sugieren algunas observaciones de Ramón Margalef, la ciudad humana tiene un cierto paralelismo con un árbol. En ambos, sólo una pequeñísima fracción del peso total es materia viva. La mayor parte de un árbol es materia mineral que asegura que esa pequeña fracción de biomasa pueda mantener una forma estable, disputar por la radiación solar y por los nutrientes de la tierra. La ciudad moderna perdió su alma colectiva: claramente desde el Barroco, la ciudad comenzó ha ser planificada como una máquina, y ha dejado de ser expresión de la materia viva en su continuo nacer y morir. En un sentido preciso, la ciudad planificada ha significado la vuelta al "trogloditismo": a sus habitantes sólo les queda conseguir un agujero, que no han construido ni organizado a su capricho y necesidad, e intentar convertirlo en un nicho ecológico, rodeado de trogloditas compitiendo por recursos escasos. Paradójicamente, el sueño de construir un hogar sólo se alcanza, a veces, al acceder a la "segunda residencia" de fin de semana.

${ }^{15}$ Hay otro factor de fundamental importancia, sobre todo en este siglo: la implantación de la agricultura química en el mundo rural y la consiguiente drástica disminución de la mano de obra necesaria, empujó y forzó a un buen número de campesinos hacia la ciudad. Difícilmente esas corrientes migratorias podían tratar como propia una ciudad que era el destino del exilio. Se encontraron en un mundo ajeno, en el que nunca se les ha ofrecido la oportunidad de hacerlo propio. Como cabía esperar, ambos factores, junto a otros, se reforzaron mutuamente en la destrucción del alma colectiva de la ciudad. La construcción de la ciudad sostenible pasa por recuperar el control del ciclo completo de energías y materiales que permiten nuestra existencia. Y para empezar debemos recuperar su percepción eliminando la lejanía. Calmar el tráfico en todos los planos y distancias resulta por tanto una labor prioritaria iy no me refiero 
La ciudad tiene que ser abarcable apenas sin esfuerzo. Para nuestras grandes metrópolis se ha sugerido y en ocasiones experimentado su troceo en barrios-ciudad, tal y como ha propuesto Agustín Hernández. Trozos de tamaño suficiente como para dar cabida a la complejidad de lo urbano y a su diversidad, pero no tan grandes que el ciudadano los desconozca. Trozos en los que la población pueda, para empezar, construir por sí misma su propia centralidad, su identidad colectiva. No se trata desde luego de construir fronteras arbitrarias: igual que fue posible construir la ciudad global mediante el diseño de redes de comunicación e ingentes inversiones en infraestructuras, es posible trocear la ciudad reformando sus sistemas de transporte: si las circunvalaciones y las autopistas nunca fueron expresión de un proyecto colectivo, su remodelación podría serlo. A medida que la conciencia de nuestros problemas ha ido creciendo, gracias a una paciente y pertinaz labor de denuncia del movimiento ecologista, a veces basta con una cierta masa crítica de personas informadas y alguna circunstancia favorable para que el proceso, al menos, comience. Cada experiencia tiene sus propias particularidades, aciertos y fracasos, de manera que no tendría sentido aquí una exposición de recetas, trucos y reglas para la rehabilitación ecológica de la ciudad: lo que en unos sitios puede servir en otros puede fracasar. Lo único que las distingue a todas ellas es, precisamente, ese afán por una nueva acción política democrática que permita reconstruir el alma colectiva de la ciudad. ${ }^{16}$

sólo al automovilístico! Una vez podamos ver, podremos conocer, valorar y controlar. La recuperación de la ciudad construida, modificada, rehabilitada por sus ciudadanos es por tanto una condición imprescindible para su sostenibilidad. El ciudadano tiene que recuperar la posibilidad de dejar huella en la ciudad que habita, como pasó y pasa en algunas ciudades, como siempre hizo la célula viva en el árbol. Una democracia entendida como un proceso electoral no ayuda mucho aquí. Idealmente, en el ágora de la ciudad deberían caber representantes de todas sus familias y tribus, que deberían poder realizar el deseo primero de lo urbano: estar juntos, verse y tocarse las caras. Es necesario por tanto un tamaño de ciudad, de espacio urbano, acorde con la posibilidad de percibir la totalidad o la mayor parte posible de personas, objetos, energías, información que la forman.

${ }^{16}$ Los problemas de la incidencia de la ciudad sobre su entorno y sobre las propias condiciones de vida de sus habitantes son tan viejos como la ciudad misma (señala el profesor José Manuel Naredo). Pero la enorme expansión de las ciudades propia del siglo XX y la mutación observada en su comportamiento, originaron problemas ambientales sin precedentes en dimensión y características. Cuando el creciente proceso de urbanización hace que en este fin de siglo ya cerca de la mitad de la población mundial habite en ciudades, la problemática ambiental de éstas trasciende claramente de los niveles localmente anecdóticos en los que se situaba en el pasado: la calidad de vida, e incluso la supervivencia, de la humanidad estará en buena parte condicionada por su capacidad para conocer y controlar la relación de las ciudades con su medio ambiente. Pues a medida que la población y la urbanización aumentan, las condiciones de vida de las ciudades dependerán cada vez más de la propia habitabilidad de la Tierra. Interesa, pues, reflexionar sobre los rasgos esenciales de la configuración y el funcionamiento de los sistemas urbanos actuales, para poder modelizarlos y reorientarlos. Pues como creaciones humanas que son, cabe considerarlas revisables y modificables. El problema estriba en disponer del aparato conceptual y del marco institucional necesarios para 
Mientras que puede decirse que el elevado grado de autonomía de las aldeas ha evidenciado su tradicional adaptación al aprovechamiento sostenible de los recursos locales, el poblamiento disperso que las conurbaciones de hoy día esparcen por el territorio se caracteriza por su elevada dependencia de unos ingresos ajenos al suelo que ocupan y por un uso mucho más dispendioso de los recursos del que tenía lugar en los antiguos "cascos". De esta manera, a la secular sostenibilidad paradigmática de las aldeas, se contrapone hoy la extrema insostenibilidad de las urbanizaciones de residencias unifamiliares que rodean a los núcleos más densos de la conurbaciones ${ }^{17}$ (Valenzuela, L.M. 2011).

Este avance en la utilización más extensiva del territorio y en la separación en el mismo de funciones y usos específicos que antes se solapaban, se apoya sobre el

hacerlo. En lo que sigue se enmarcará la problemática actual recordando que la naturaleza de las actuales concentraciones de población, además de ser un reflejo de la ideología y las instituciones dominantes en la presente civilización, resulta de la superposición de las soluciones parciales que se fueron dando a los problemas de habitabilidad y salubridad urbana que plantean las grandes concentraciones de población.

${ }^{17}$ A partir de entonces aparecen ya esbozadas las claves de la estructura que permitirá mantener las condiciones mínimas de habitabilidad en concentraciones de población que en muchos casos llegan a superar los diez millones de habitantes e incluso, en ocasiones, a rozar los veinte. Pese a la gran disparidad de densidades de población que observan las actuales conurbaciones, cabe señalar, como característica general de su evolución, que observan un mayor crecimiento en extensión que en población. El mantenimiento e incluso la mejora de la calidad del medio ambiente urbano que se observa en las conurbaciones de los países desarrollados, se ha conseguido así, no sólo segregando y alejando las actividades y residuos más problemáticos, sino también reduciendo la presión de la población y de los usos por unidad de superficie. La mayor ocupación de territorio por habitante que se observa resulta de dos fenómenos diferentes. Uno viene dado por la menor densidad de población registrada en las sucesivas "coronas" metropolitanas: alrededor del núcleo más denso de la conurbación aparece un archipiélago de poblamientos cada vez más disperso que alcanza hasta zonas más alejadas de segunda residencia. Otro por la creciente ocupación de espacio por las redes y las áreas de servicio, abastecimiento y vertido. Por ejemplo, en el caso de la provincia de Madrid se ha duplicado la superficie ocupada por habitante para usos urbanos directos e indirectos entre 1956 y 1980 (con el agravante de que dicha mayor ocupación se ha dirigido preferentemente hacia los suelos agrícolas de mejor calidad). A la vez que se ha podido comprobar que mientras en 1956 la superficie ocupada por usos urbanos indirectos (embalses, vertederos, actvidades extractivas, suelo en promoción y carreteras) representaba sólo el 10 por 100 del total ocupado, en 1980 pasó a representar el 23 por 100 , y si se incluye la superficie de cultivos abandonados (inexistente en 1956), este porcentaje se eleva al 35 por 100 (García-Zaldivar, R. et alii., 1983). Es decir, que la conurbación madrileña derivó, en el período indicado, hacia un modelo de urbanización que hace un uso mucho más dispendioso del territorio, ya que por cada dos hectáreas de usos urbanos invalida al menos una para otros usos, pese a la imagen de ahorro de espacio que ofrece el mayor volumen edificado en las zonas más densas. Y como se indicará más adelante, este comportamiento territorial resulta cada vez más costoso en recursos y en residuos. 
eficaz manejo de un entramado cada vez más complejo de redes que facilitan el transporte horizontal de energía, materiales, personas e información, tanto en el seno de las propias conurbaciones, como entre éstas y el resto del territorio. La propia eficacia de las redes no sólo posibilitó la extensión superficial de las conurbaciones, sino que la propició, incentivando con ello formas de vida mucho más costosas en recursos. Por ejemplo, es la propia mejora en la calidad y velocidad de las redes de transporte la que hizo que la longitud de los desplazamientos pendulares trabajodomicilio se multiplicara por dos en Francia entre 1975 y 1990, pasando de 7 a 14 kilómetros (Beaucire, F., 1995). En este mismo sentido "se han comparado las consecuencias del automóvil en la ciudad a los de una bomba lenta, una bomba cuya onda expansiva tuviera la virtud de trasladar edificios y actividades, aparentemente intactos, a muchos kilómetros a la redonda, y cuyo principal efecto en el interior fuera el de destruir la propia esencia de las urbes: la convivencia y la comunicación entre los seres humanos"(Estevan, A y Sanz, A, 1994). ${ }^{18}$ (Valenzuela, L.M. 2011).

"La práctica urbanística -explican estos autores- trata de racionalizar la nueva localización de las actividades creando polígonos especializados que cumplen una sola función: zonas comerciales, parques empresariales, barrios dormitorio, áreas de ocio especializado o zonas escolares, todas ellas crecientemente alejadas entre sí... En círculo vicioso, las mayores distancias a recorrer exigen más desplazamientos motorizados, que acaban reclamando nuevo espacio a devorar. Un resultado significativo de todo ese proceso de alejamiento de usos es la creciente expansión del espacio urbano al margen ya de la evolución demográfica... Desgraciadamente, las consecuencias de la motorización no acaban ahí. La segregación espacial opera también en la escala del barrio. El tráfico plantea barreras a veces infranqueables entre las dos aceras de una misma calle...". El elevado coste que supone la instalación

18 El uso generalizado del automóvil ha contribuido así a alterar profundamente el paisaje urbano, haciéndolo más inhóspito como espacio de encuentro colectivo. Por una parte demandó continuamente mayores superficies destinadas al transporte, provocando la reconstrucción del tejido urbano de acuerdo con sus exigencias, sacrificando no sólo la ciudad a la avenida, sino a ésta en aras del tráfico rodado, con los consiguientes problemas de segregación, ruido y contaminación atmosférica de todos conocidos. Por otra contribuyó a salpicar la ciudad por todo el territorio, prolongando las edificaciones a lo largo de todo el viario circundante y extendiendo mucho más allá su radio de influencia, a través de segundas residencias e instalaciones de acogida de fin de semana y vacaciones. Con el agravante de que la "puesta en valor" de nuevas zonas supuestamente "naturales", o al menos rurales, atraía hacia ellas la aglomeración, la edificación y las formas de vida que se pretendían dejar atrás, provocando paulatiamente la pérdida de los valores que en principio las hicieron atractivas. Recordemos que la dispersión de la ciudad originada por el automóvil lejos de evitar la congestión, la agravó con los obligados desplazamientos pendulares que todo lo atascan. Una vez más surge la paradoja de que la máquina que prometía la rapidez y libertad de desplazamiento, origina diariamente en sus usuarios la frustración del embotellamiento, a pesar de las costosas infraestructuras que se ponen a su servicio, a la vez que constituye uno de los principales factores de deterioro del medio ambiente urbano (Naredo, J.M., 1998). 
y el buen funcionamiento y uso de las redes de las que hoy dependen la habitabilidad y la calidad del medio ambiente urbano, plantea serios problemas para hacerlo extensivo al conjunto de la población y el territorio de las conurbaciones, sobre todo en los países más densamente poblados, en los que este propósito exige una ordenación y un maquillaje del territorio cada vez más complicado y costoso. Lo que plantea nuevos problemas no sólo sobre la sostenibilidad y habitabilidad globales, sino también locales, de este modelo de asentamiento. Pues el hipercrecimiento de las conurbaciones acrecienta los costes y la dificultad para mantener en todo su territorio las mejoras que se habían ido alcanzando en las condiciones locales de habitabilidad desde hace más de un siglo. Ello no sólo en las conurbaciones de los países "del Sur", que son teatro de graves problemas ambientales y en las que buena parte de la población permanece al margen de estas mejoras, sino también en las "del Norte", donde las condiciones de habitabilidad tienden a flexionar para ciertas zonas "en declive" y segmentos de población menos favorecidos.

En países tan densamente poblados como los europeos, estas formas de poblamiento y ocupación extensivas culminan con la disolución de los límites entre la ciudad y el campo. Asistimos en ellos al panorama de continuos urbanos que se extienden y solapan, sin límites precisos, a lo largo del territorio siguiendo el mismo orden desordenado, en el que se alternan distintas variantes de edificación en densidad, trazado y calidad, con territorios ocupados por las redes e instalaciones que tales asentamientos reclaman (viario, embalses, vertederos, canteras, graveras,...). Pero, ya ni el conjunto de las edificaciones más densas puede decirse que configure una ciudad, ni el territorio circundante que sea el campo, el medio rural o el medio físico, sino una prolongación de ese continuo urbano que todo lo alcanza y mediatiza.

Desde el año 1997 hasta la actualidad, en España se ha desarrollado una continua e importante revisión del marco legal en materia de urbanismo lo que ha repercutido de manera directa y, en cierto modo, negativa en la transformación de la ciudad española en la última década del siglo pasado y, más concretamente, en los prolegómenos del siglo XXI. Si bien, en materia medioambiental las constantes modificaciones del planeamiento general inducido por la aplicación de soluciones políticas en materia de urbanismo y ordenación del territorio forzadas por los acontecimientos, no ha servido para contener el creciente despilfarro de recursos territoriales y el encarecimiento de suelo y vivienda a pesar de ser éste el propósito de su promulgación (Marmolejo, Aguirre y Ruiz, 2010). Por otro lado, la hipertrofia normativa ha contribuido a amparar y justificar múltiples operaciones de reserva y transformación de suelo manifiestamente especulativas, por innecesarias, transformado con ello, de forma irreversible, su paisaje y estructura urbana; una estructura que quedará conformada por dos grandes unidades: la vieja ciudad ocupada y la nueva ciudad vacía, como paradoja del despilfarro tutelado de la primera década del siglo XXI (García López, 2007). Todo ello desde la perspectiva de reducir lo que podríamos denominar "complejidad normativa", a la par que se abarataba el precio del suelo (objetivos en conflicto en el desarrollo urbano). (Valenzuela, L.M. 2011). 
Si por alguna característica puede definirse el periodo amparado por la legislación urbanística de rango estatal y autonómico promulgada tras la entrada en vigor de la Constitución Española y la sentencia 61/1997 de 20 de Marzo de 1997 del Tribunal Constitucional, es sin duda por el alto grado de hipertrofia normativa (Font, 2004). Cuestión más que relevante si se tiene en cuenta que, normalmente, es una solución a los problemas que una ley anterior de naturaleza similar no ha resuelto, porque el reemplazo de la norma se produce cada vez en ciclos más cortos y que el tiempo de respuesta de la norma autonómica a los cambios de carácter general es muy desigual $\mathrm{y}$, de igual modo, porque que es frecuente que coexistan, durante años, leyes de nueva factura con planes generales en vigor, diseñados conforme a una legislación derogada, tal y como señalan (Rullan, 2010). Se trata, sin duda, de un problema que el legislador conocía a la perfección, asumiendo la evidente y estrecha relación entre la multiplicidad de regímenes normativos y el incremento del precio del llamado "producto final". En la exposición de motivos de la ley 6/1998, de 13 de abril, sobre Régimen del Suelo y Valoraciones -vigente hasta el 1 de julio de 2007- se señalaba que "Las sucesivas reformas de nuestra legislación urbanística han ido incrementando la complejidad de este sector del ordenamiento jurídico al multiplicar, a veces innecesariamente, las intervenciones administrativas en las distintas fases de los procesos de desarrollo urbano, lo que, unido a la limitación de la oferta de suelo, ha contribuido decisivamente a demorar hasta extremos irrazonables la conclusión de las operaciones de urbanización y ulterior edificación, haciendo imprevisible su coste y dificultando una adecuada programación de las correspondientes actividades empresariales, con el consiguiente encarecimiento del producto final'. Un problema que, lejos de resolverse, acabará por agravarse al sumar a la diversidad normativa regional y la restricción a la competencia que de ello se deriva, la propia complejidad interna de cada norma autonómica, como estrategia para justificar su propia existencia, apelando a la singularidad -histórica, territorial, cultura, etc.- del territorio que con ella se administra y regula (Rullan, 2007).

Si bien, a pesar de lo expuesto, debemos tener en cuenta que la legislación en materia de urbanismo apenas ha contribuido, y mucho menos en los últimos años, a que se lleven a cabo el objetivo principal de reducir la complejidad normativa, sobre todo si tenemos la gran variedad de cambios; puesto que la innumerable cantidad de instrumentos necesarios y la compleja tramitación que de ordinario precisan, así como el cambio en las soluciones que los propios instrumentos se imponen regularmente mediante modificaciones puntuales, corrección de errores materiales, subsanación de deficiencias, recursos, anulaciones, etc.-, resultan disuasorios para muchos agentes, ya que elevan los plazos para la ejecución de cualquier proyecto -con el coste financiero que ello representa-, fomentando sensu contrario, un fuerte oligopolio en el sector que limita la competencia -casi por exigencia legal-e impide la consecución de otro de los grandes objetivos de la ley: el abaratamiento del precio del suelo y de la vivienda (Rodríguez, 2010). Por ello, se ha evolucionado desde un sistema de especulación totalmente consentida hacia un sistema menos permisivo con el que conocer y controlar los impactos ambientales, en general y sobre los recursos hídricos, en particular; con el fin de permitir el crecimiento, expansión y equipamiento de las 
urbes españolas, sin limitar y degradar su medio físico-ambiental. (Valenzuela, L.M. 2011).

Si bien, como afirma (Portas, 2003) es habitual la existencia de inversiones que se pueden calificar de "perversas" cuando se produce la creación o expansión de una ciudad, puesto que no es la urbanización la que justifica una dotación, sino al revés. Es decir, la creación de unas canchas de de baloncesto, un campo de golf, un centro comercial o un centro de salud, es el que justifica y en muchos casos incluso la creación de una nueva urbanización. De este modo, con el fin principal de disminuir o eliminar dichos impactos en la ley 6/1998, de 13 de abril, sobre Régimen del Suelo y Valoraciones -vigente hasta el 1 de julio de 2007- se fijaba como primer objetivo "reducir la complejidad normativa, codificando dentro del aclarado marco competencial, el conjunto de preceptos reguladores del urbanismo". Un propósito encomiable, pero relegado al olvido ya que, generalmente por causas ajenas y sobrevenidas, todas las Comunidades Autónomas tuvieron que afrontar múltiples reformas de su normativa urbanística, que, además, parecen no tener fin por el carácter transversal que frecuentemente tiene la misma. Todo ello sin olvidar el significado de las instrucciones y normas técnicas urbanísticas, técnicas que desarrollan algunos aspectos de la ley y con las que se pretende solucionar tanto problemas de interpretación, falta de homogeneidad en la aplicación de la ley o tramitación de los planes, como regular la adaptación de la ley y del reglamento a los cambios en la normativa estatal (ver Harvey, D., 2007).

Es cierto, no obstante, que merced a este considerable corpus normativo en materia de urbanismo, se ha dado un salto considerable en la ordenación urbanística municipal en España, hasta el punto de que en esta última, y entre ellos, la totalidad de los núcleos de más de 5.000 habitantes, con la particularidad de que tan alto grado de cobertura territorial se ha alcanzado en la última década. (Valenzuela, L.M. 2011).

$\mathrm{Y}$ en la base de este espectacular crecimiento del precio de la vivienda se encuentra el precio del suelo. Según datos del Instituto Valenciano de Investigaciones Económicas -IVIE-, el precio del suelo en España entre 1990 y 2008 creció a una tasa media anual acumulativa del $14,5 \%$, en tanto que en la etapa entre las dos leyes de suelo estatales, es decir en el periodo 1997-2007, el precio del suelo creció al $25,2 \%$ anual, de lo que se derivó un fuerte aumento de su repercusión en el precio de la vivienda, ya que de representar un $29 \%$ en 1990 pasó a un 46,2\% en 2008 (Uriel, 2009). Si consideramos que en el año 2000 la repercusión de esta variable en el precio final era inferior a la del año 1990, es fácil resaltar el vertiginoso crecimiento habido en los siete primeros años del siglo XXI, los años centrales del "boom" inmobiliario de herencia finisecular (IVIE, 2010).

Y es que, en todas las ciudades se duplica el precio de la vivienda, pese a que en la mayor parte de ellas se ha delimitado y urbanizado suelo y se han construido viviendas como en ningún otro periodo de su historia reciente. Los planes generales aprobados en la década de los años noventa de siglo XX y primeros años del XXI, que contemplaban el suelo urbanizable en conjunto como "residual", tras delimitar el suelo urbano y el suelo protegido, pusieron en el mercado una gran superficie de 
suelo apto para ser urbanizado, que llega a serlo de forma efectiva al aprovechar una favorable coyuntura económica y una sensible reducción del precio del dinero, alimentado además en España por la llamada "guerra de las hipotecas", como describe el profesor Luís Miguel Valenzuela (2011).

En estas condiciones, el número de proyectos aprobados y de viviendas iniciadas y terminadas crecerá casi de forma exponencial, pero como muchas fueron compradas no para su uso, sino para su ulterior venta aprovechando los beneficios que generaba esta operación, en la actualidad, tras la crisis de 2007, permanecen muchos meses y años vacías y no consiguen venderse ni asumiendo importantes descuentos en el precio final, al haberse encarecido y reducido el acceso al crédito hipotecario (Portas, 2003). Estos ambiciosos planes parciales residenciales conforman ahora las nuevas periferias vacías de las ciudades que, como paradigma del despilfarro, se suma al vacío dejado en la ciudad tradicional tras años de abandono y falta de inversión pública y privada en su conservación, con la sola excepción de aquella que estuvo encaminada a convertir el centro en un producto turístico, de deslumbrante fachada pero carente de la actividad y del entramado social que tuvo en el pasado (Rullan, 2007). Además, lo anteriormente expuesto queda reflejado en una problemática muy compleja de endeudamiento de las ciudades españolas, que se refleja en la información recogida en los mapas adjuntos. (Valenzuela, L.M. 2011).

Por ello, se hace imprescindible argumentar lo expuesto mediante una cartografía clara, a la par que sencilla como la que se adjunta, dado su carácter complementario, que debe ser analizada conjuntamente, pues de este modo representa fielmente una ajustada imagen de la dinámica urbano-metropolitana en España. La España urbana que ha pasado de un modelo fuertemente polarizado y de transición (Mapas 1 y 2) a otro en el que las áreas metropolitanas y el fenómeno de urbanización solo caben ligarse a las grandes ciudades como Madrid, Barcelona, Valencia, Sevilla, Bilbao (Mapa 3) llegando a generar un cuarto modelo cartográfico como el actual referido a 2010 (Mapa 4) en el que todos los núcleos urbanos de cierta entidad inician proceso de expansión y de difusión urbana (urban sprawl) originando un fenómeno de periurbanización, cada vez más acelerado, como consecuencia del cual los límites entre los rural y lo urbano se hacen cada vez más difusos y la dualidad rural urbana patente hasta 1981 se ve sustituida por la gradación espacial en la intensidad demográfica en áreas urbanas (Mapa 5) (ver Harvey, D., 2007). 
Mapa 1. Población Urbana en España, 1900.

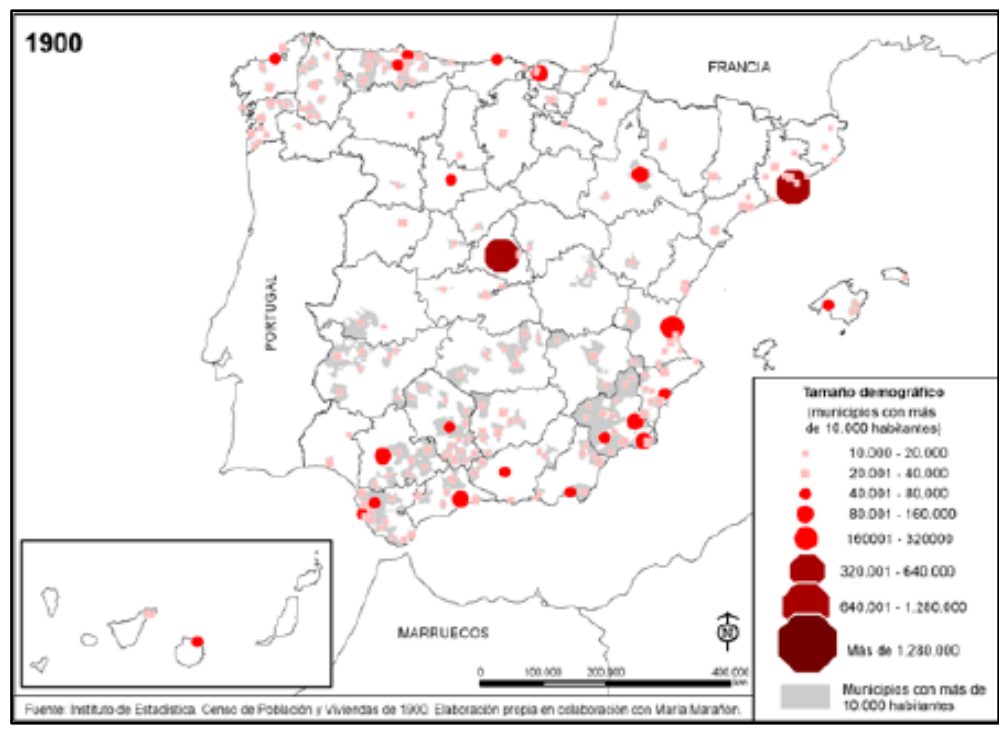

Fuente: De Cos Guerra, O. y Reques Velasco, P. (2011). Elaborado a partir del Instituto Nacional de Estadística. Censo de Población y Vivienda de 1900.

Mapa 2. Población Urbana en España, 1950.

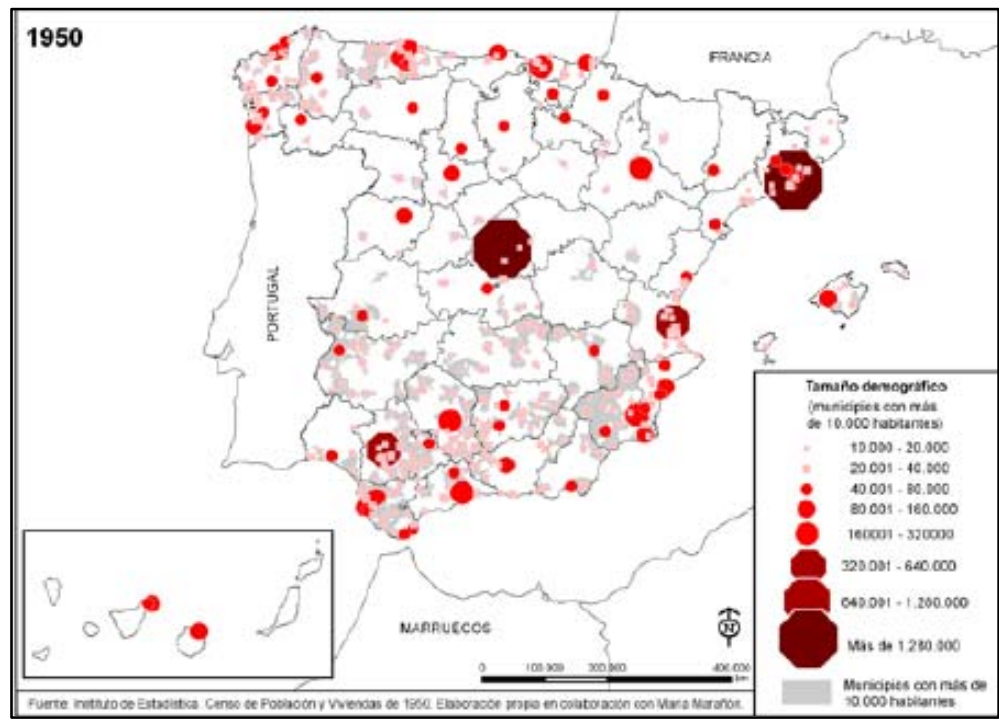

Fuente: De Cos Guerra, O. y Reques Velasco, P. (2011). Elaborado a partir del Instituto Nacional de Estadística. Censo de Población y Vivienda de 1950. 
Mapa 3. Población Urbana en España, 1981.

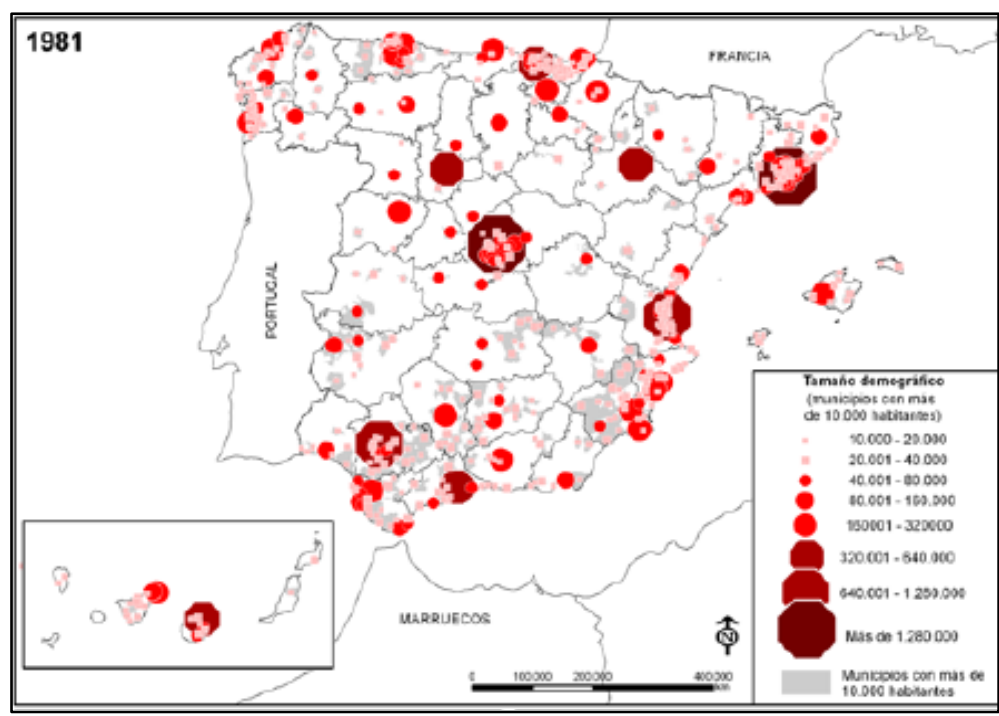

Fuente: De Cos Guerra, O. y Reques Velasco, P. (2011). Elaborado a partir del Instituto Nacional de Estadística. Censo de Población y Vivienda de 1981.

Mapa 4. Población Urbana en España, 2010

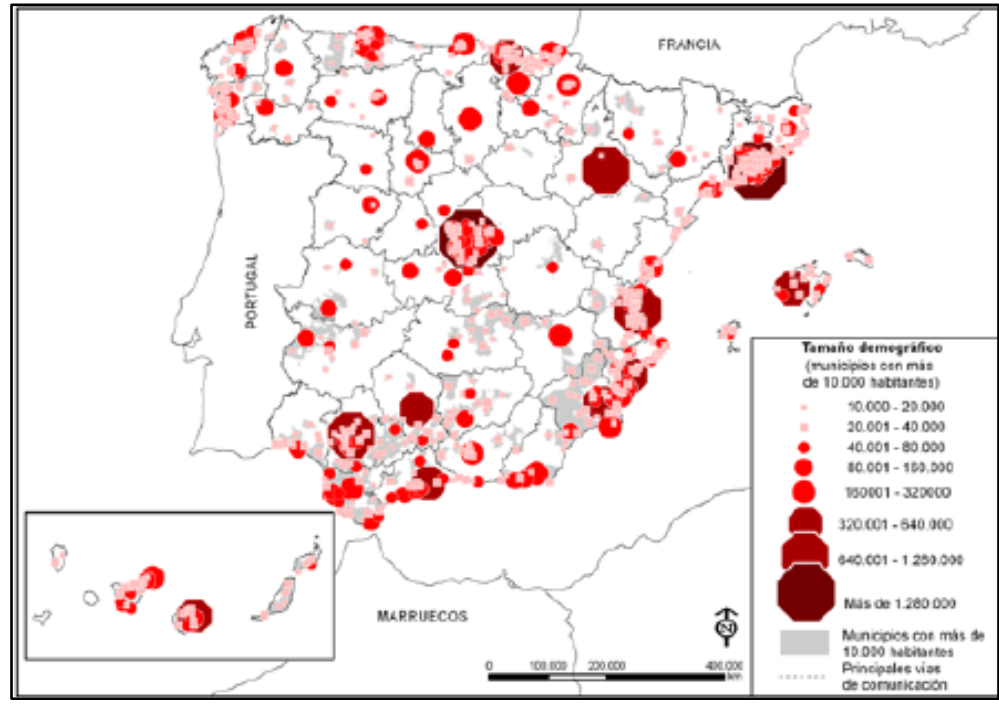

Fuente: De Cos Guerra, O. y Reques Velasco, P. (2011). Elaborado a partir del Instituto Nacional de Estadística. Censo de Población y Vivienda de 2010. 
Mapa 5. Gradación espacial en la intensidad demográfica en áreas urbanas.

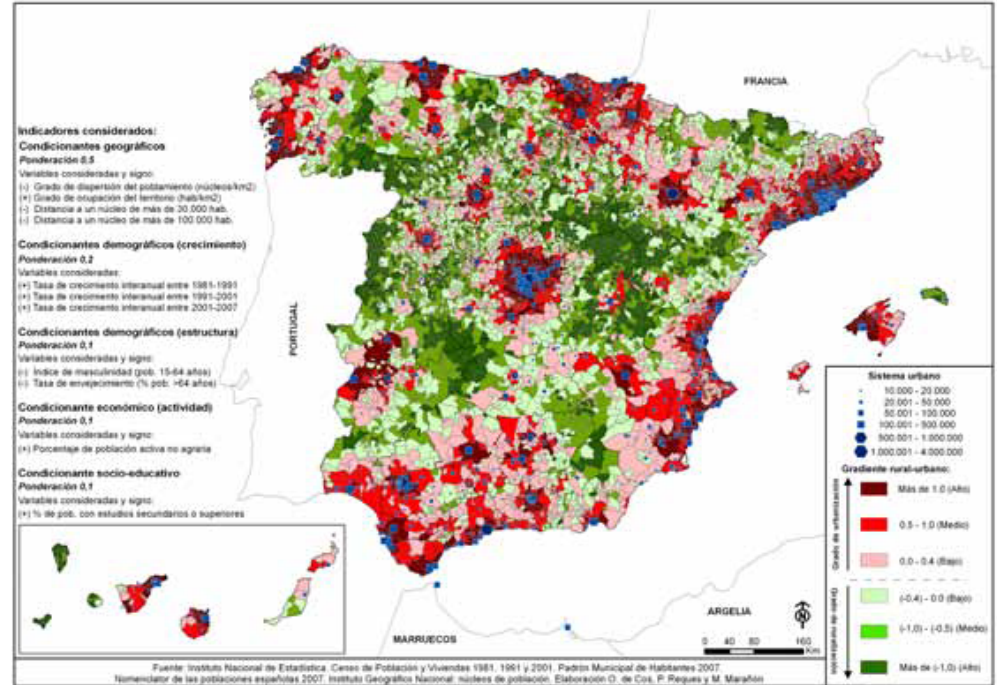

Fuente: De Cos Guerra, O. y Reques Velasco, P. (2011). Elaborado a partir del Instituto Nacional de Estadística.

Mapa 6. El crecimiento urbano y sus comunicaciones.

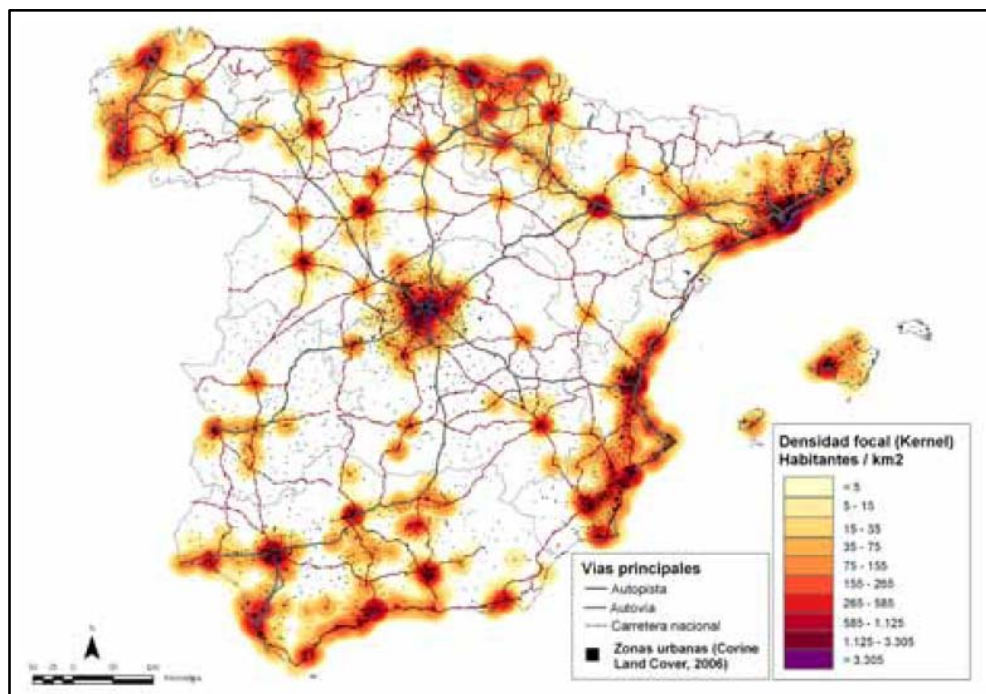

Fuente: De Cos Guerra, O. y Reques Velasco, P. (2011). Elaborado a partir del Instituto Nacional de Estadística. 
Las áreas urbano-metropolitanas están experimentando diferentes procesos y tendencias que derivan en características funcionales, socio-demográficas y territoriales específicas reconocibles, incluso, en un análisis de base municipal y más aún si -como en el presente estudio- se incorporan los patrones de poblamiento y el sistema de asentamientos (Farinos y Romero, 2007).

A partir de los rasgos geográficos, demográficos, económicos, sociales y funcionales se constata empíricamente en España una organización supra-municipal que pone de relieve la configuración de rasgos metropolitanos relativamente homogéneos en los municipios próximos a los principales núcleos urbanos (Nel.lo, 2004).

Los municipios más urbanizados conforman áreas metropolitanas de límites cada vez más amplios, difusos e imprecisos, apoyados en los principales ejes de transporte.

En todo lo anteriormente expuesto, como describe el profesor Luís Miguel Valenzuela (2011), influyen de modo determinante diversos factores de difícil sistematización -urbanísticos, políticos, económicos, culturales, etc.-, si bien, en la configuración espacial de las áreas metropolitanas las comunicaciones cobran un protagonismo especial y en ellas se está produciendo un rápido cambio y una expansión territorial difusa que comienza a convivir en los últimos años con nuevas tendencias de compensación del decrecimiento de los espacios centrales (Nel.lo, 2004), tal y como se puede ver en el Mapa 6, pero no del proceso de salida de ciertos sectores de población residente en el municipio central. En definitiva, los espacios urbano-metropolitanos muestran una evolución, cuyo análisis es necesario para detectar las nuevas tendencias y conocer y definir el perfil de los diferentes patrones territoriales urbano-metropolitanos, con el fin de anteponerse a sus repercusiones socio-económicas y afrontar su planificación territorial futura.

En este sentido, la cartografía estadística, los SIG, el método de las densidades focales (Moreno, 1991; Escolano, 2002; de Cos, 2004) y los análisis multicriterio representan las herramientas técnico-metodológicas más idóneas para enfrentarse a las mismas. (Harvey, D., 2007)

\subsection{DEUDAS POR PAGAR, UN CONFLICTO URBANO DE AHORA Y DE SIEMPRE}

Las áreas urbano-metropolitanas a partir de su complejidad se han ido endeudando notablemente a lo largo de la última década, tal y como se recoge en el mapa número 7. Entre ellas destaca Jerez de la Frontera (Cádiz, 211.000 habitantes) se ha convertido en una de las ciudades que peor ha digerido la resaca de la crisis en España.

Hace un par de años la revista estadounidense Time publicó un reportaje sobre el colapso financiero del bullicioso municipio andaluz para reflejar las dificultades por las que atravesaba el país (Farinos y Romero, 2007). La mala gestión ha llevado a Jerez a ser el municipio de España que más aumentó la deuda durante la crisis, entre 2008 y 2013, según datos del Ministerio de Hacienda recopilados por este periódico. En segunda posición, encontramos al término municipal de Parla entre los grandes 
Ayuntamientos — de más de 100.000 habitantes_- que más han incrementado la deuda per cápita durante la crisis. Desde entonces, las cosas han mejorado algo en la localidad gaditana que estuvo a punto de entrar en bancarrota si no hubiera sido rescatada por el Estado.

Mapa 7. Variación de la deuda en España.

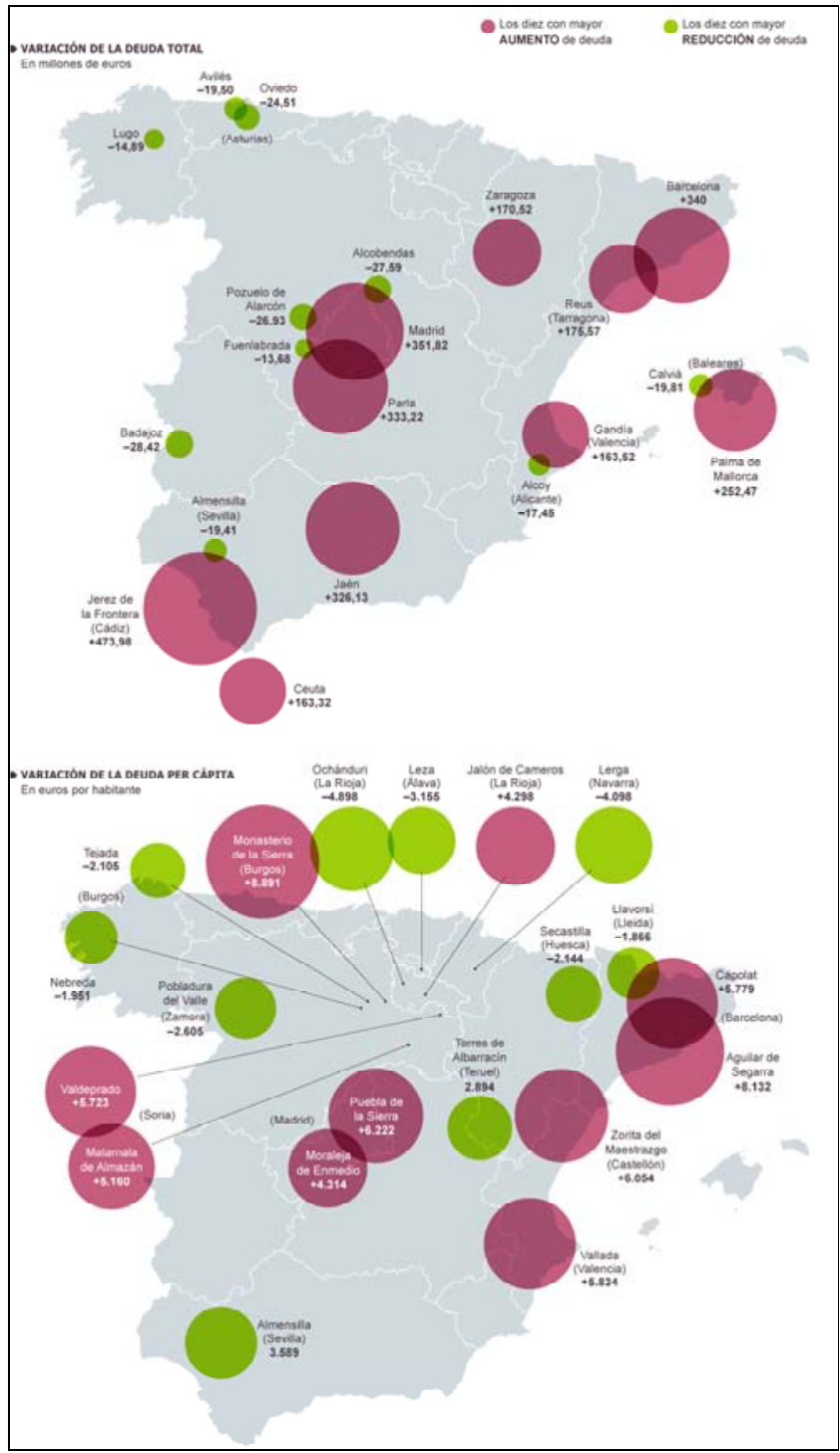

Fuente: Sérvulo, J. (2012) 
La mayoría de Ayuntamientos gestionaron mejor la abundancia y sortean la escasez mejor que Jerez o que Parla y Jaén, otros dos ejemplos de desfase. Un total de 2.374 municipios lograron reducir la deuda en 1.213 millones. Otras 2.437 localidades no deben nada, según la información remitida por la central de información de riesgos del Banco de España (CIRBE), utilizada por Hacienda, que recoge las obligaciones financieras.

La venta de suelo y las promociones inmobiliarias eran máquinas de fabricar billetes que atraía a los más voraces. Muchos alcaldes multiplicaron los ingresos de sus municipios gracias a las licencias urbanísticas, recalificaciones y ventas de parcelas municipales. Crearon estructuras de gastos sobredimensionadas. Ofrecieron servicios públicos que en condiciones normales no podían costear (Prieto et alii, 2011). Y en 2008, cuando el crack financiero pinchó la "burbuja inmobiliaria", cientos de municipios se quedaron con las cajas vacías y una abultada factura.

$\mathrm{Y}$ es que, la mayor parte de los ingresos de los ayuntamientos proceden del impuesto sobre bienes inmuebles (IBI), un tributo que está ajeno al ciclo económico. Por ello, tras la crisis de la construcción, muchas entidades municipales han subido este impuesto para compensar la caída de la recaudación de los tributos vinculados al ladrillo. Los ingresos por el IBI han crecido un 40\% desde 2008, hasta unos 11.500 millones. De hecho, el equilibrio es la norma de las entidades locales, en los que casi la mitad del aumento de la deuda municipal en la crisis se debe a solo medio centenar de Ayuntamientos mal gobernados (Prieto et alii, 2011). Estos han atraído la atención de los mass media y han extendido la impresión de que todos estaban descontrolados pero la mayoría no tenía tantos problemas.

Por el contrario, nos encontramos con el Ayuntamiento de Badajoz, que es el que más redujo la deuda durante la crisis y el segundo que más la rebajó por habitante desde 2008. Esta cálida ciudad de 150.000 vecinos ha sido un ejemplo de prudencia financiera. Durante los años de crisis inmobiliaria destinó los ingresos extraordinarios procedentes de esta actividad a ahorro en vez de aumentar el gasto estructural, como dictan los manuales de economía. Y con ese ahorro pudieron invertir sin recurrir a nuevos créditos ajustando los gastos. Aunque no son tantos los municipios que presentan problemas graves, el Gobierno lanzó el año pasado un salvavidas para rescatar a más de trescientos entidades locales (Rodríguez López, 2006). La dura lección por los excesos y la Ley de Estabilidad Presupuestaria, aprobada en 2012, han servido para controlar las finanzas locales. Aunque aún hay casos con serios problemas, la mayoría tiene sus cuentas saneadas.

En definitiva, debemos ser conscientes de que España ha experimentado en las últimas décadas un acelerado proceso de urbanización, plasmado en la existencia de un amplio conjunto de realidades metropolitanas que se han ido gestando y ampliando espacialmente de forma difusa en las proximidades de los principales núcleos urbanos. Las implicaciones territoriales de este proceso, la progresiva ocupación del territorio, las nuevas configuraciones espaciales de las ciudades, la expansión de sus áreas de influencia y la configuración del sistema metropolitano actual vienen siendo un objeto de estudio destacado, especialmente desde el último cuarto del siglo XX (Vinuesa, 1975; Capel, 1975 y 2003; Precedo, 1986; Rodríguez y Reques, 2000; 
Santos, 2000; Serra, 2002; Roca, 2003; Feria, 2004; Roca et alii, 2004; Ministerio de Vivienda, 2005; Boix, 2007, entre otros). Estos trabajos permiten constatar que no existe consenso de los espacios configurados en torno a los principales núcleos urbanos (aglomeraciones urbanas, grandes áreas urbanas, aglomeraciones metropolitanas, áreas metropolitanas, regiones metropolitanas, etc.) y que no están inequívocamente definidos ni establecidos los principales rasgos, criterios definitorios, indicadores y umbrales propios del fenómeno metropolitano en España. Las principales ciudades del sistema urbano español presentan desde la década de los 80 un importante proceso de descentralización, ligado en parte a la especialización residencial periférica y al declive demográfico de la ciudad central, que ha supuesto un cambio de tendencia frente a la trayectoria centralizadora de décadas anteriores (Feria, 2004).

\subsection{SOSTENIBILIDAD URBANA Y NUEVAS POLÍTICAS DE ACTUACIÓN CONTRADICTORIAS}

El crecimiento económico está estrechamente relacionado con el desarrollo urbanístico, y es que, es cierto que el crecimiento de los núcleos de población conlleva aspectos positivos, relacionados especialmente con el desarrollo de la economía, pero al mismo tiempo también crea y agrava algunos problemas ambientales (Nel·lo, 2004). Así, el crecimiento urbanístico muchas veces está unido a la ocupación de suelos fértiles, a la contaminación de suelos y aguas subterráneas, a la deforestación, a la contaminación del aire, a un mayor uso de los recursos naturales, etc. Además, en ocasiones el desarrollo urbanístico de los núcleos de población pretende el crecimiento poblacional de los municipios sin tener en cuenta las necesidades de infraestructuras y servicios de los nuevos habitantes. En muchos casos, se llevan a cabo actuaciones urbanísticas que dan lugar a municipios con varios núcleos de población dispersos y alejados entre sí, lo que implica, entre otros aspectos, una necesidad mayor del uso del transporte, la mayoría de las veces en vehículos privados con el consiguiente consumo energético y un aumento de la concentración de ozono troposférico. La disgregación de una población en varios núcleos genera multitud de problemas a la gestión municipal (De Moral, 2008). Este tipo de urbanismo suele fomentar los agravios comparativos entre los diferentes núcleos, generando problemas de identidad y de pertenencia. Por tanto, para evitar las situaciones anteriores y conseguir que el desarrollo urbanístico sea sostenible, es necesario la aplicación de estrategias urbanas integradas, que tengan en cuenta no sólo la protección y la mejora del medio ambiente, sino también la mejora de la productividad y el crecimiento económico, la creación de empleo, el establecimiento de zonas verdes y equipamientos, la supresión de barreras arquitectónicas, la protección de la salud y la seguridad humana, la mejora de la accesibilidad y movilidad,...(ver Harvey, D., 2007)

Llegados a este punto es necesario mencionar la "Estrategia de Medio Ambiente Urbano" (EMAU) elaborada por el Ministerio de Medio Ambiente en colaboración 
con la Red de Redes de Medio Ambiente Urbano y que supone la traslación a España de Estrategia Temática Europea de Medio Ambiente Urbano (aprobada el 11 de enero de 2006), en la que se recogen los problemas ambientales que presentan las zonas urbanas de la Unión Europea y la necesidad de abordarlos de forma integrada, incidiendo en las causas que los generan. En los últimos años, las ciudades españolas han pasado de un modelo tradicional de ciudad compacta, compleja, eficiente y cohesionada socialmente a una ciudad dispersa, con una separación funcional de sus usos, donde se despilfarran los recursos naturales y en la que se produce una segregación territorial de la población en base a su capacidad económica (Estrategia de Medio Ambiente Urbano).

Los objetivos principales que persigue la EMAU son:

a) Establecer las pautas para guiar a los municipios (pueblos y ciudades) de España hacia la sostenibilidad, mejorando al mismo tiempo la calidad de vida de sus habitantes.

b) Promover el modelo tradicional de ciudad compacta, compleja, eficiente y cohesionada socialmente.

c) Modificar la tendencia actual de consumo de recursos por otra basada en la información y el conocimiento.

La EMAU está dividida en cinco grandes apartados: el urbanismo, la movilidad, la edificación, la gestión urbana y la dicotomía entre mundo rural y mundo urbano. Para cada uno de estos apartados, la Estrategia detecta los problemas actuales que le afectan, las causas de esos problemas y las tendencias futuras, los objetivos que se pretenden alcanzar con la aplicación de la Estrategia y las directrices para conseguirlos, así como el nuevo modelo que es necesario para alcanzar la sostenibilidad (Prieto et alii, 2011). No obstante, teoría y realidad no siempre coinciden en el espacio y el tiempo y el caso de las prácticas de ordenación del territorio y urbanismo en las comunidades autónomas son un buen ejemplo de ello. Sobre todo, a partir de la crisis financiera y de la "burbuja" inmobiliaria, ya que desde ese momento se produjeron tres cuestiones fundamentales que cabe destacar:

a) Paralización o reestructuración de los Planes de Ordenación Municipal en elaboración o pendientes de aprobación.

b) Estancamiento del mercado inmobiliario y quiebra de proyectos inmobiliarios ya ejecutados.

c) Avance en la elaboración de Planes Territoriales Supramunicipales.

En cualquier caso, las prácticas y consecuencias en materia de ordenación del territorio y urbanismo en la región no pueden achacar sus negativos resultados a la falta de instrumentos técnicos, pues desde diversos ámbitos de la administración y organismos colegiados se han venido elaborando todo tipo de herramientas de apoyo y asesoramiento, entre ellas la Guía de Buenas Prácticas de proyectos de 
urbanización sostenible (Pintado, 2004) en la que se afirmaba que la Guía se enmarcaba en los Objetivos de Desarrollo Sostenible Local definidos en la Red de Ciudades y Pueblos Sostenibles de Castilla La Mancha, heredera y continuación del Pacto "Ciudad-Habitable"; no obstante, se constataba que en muchos de los municipios de la región se estaba generando un crecimiento, a veces excesivo, de la periferia urbana y eso llevaba aparejado que en numerosas ocasiones se estuviera abandonando el casco urbano histórico. Esta situación chocaba con lo que se ha dado en llamar "desarrollo sostenible" (Embid, 2007).

Y es que, la descrita Guía de Buenas Prácticas en Proyectos de Urbanización Sostenible tenía por objeto definir unos criterios de actuación a considerar en la redacción de los Proyectos de urbanización e, igualmente, durante la construcción de las obras que en ellos se describían; dichos criterios estarían basados fundamentalmente en razones de desarrollo sostenible. Todo ello permitiría actuar, tanto en Proyectos de Urbanización en nuevas áreas de desarrollo urbano como en la remodelación o adecuación de espacios urbanos ya existentes. Dado que se pretendía que la Guía se convirtiera en un documento de consulta en los Municipios españoles, se planteó como un instrumento abierto en el que tendrían cabida todas aquellas propuestas realistas que fueran encaminadas a facilitar que pueblos y ciudades pudieran ser urbanizados con criterios de sostenibilidad. Es decir "construir ciudad de forma que se garantice la calidad de vida de la generación actual sin comprometer la de las generaciones venideras" (AA.VV., 2011).

En el caso español destacar los LIC-ZEC y las ZEPAS dos tipos de espacios protegidos que forman parte de la Red Natura 2000 creada por la Directiva 92/43 (art. 3.1.II). Por lo que respecta a la previa selección de los LIC y posterior declaración formal de las ZEC, el margen de apreciación de que disponen los Estados miembros es limitado (Observatorio de la Sostenibilidad, 2006). De hecho, tal y como se recoge en la STJUE de 11 de febrero de 2001 (C-67/99, 71/99 y 220/99, Comisión contra Irlanda, Alemania y Francia) se refiere a esta cuestión afirmando que: $1^{\circ}$ ) $\mathrm{La}$ selección de los lugares ha de responder sólo a criterios de carácter científico; $2^{\circ}$ ) Los lugares propuestos por los Estados miembros deben garantizar una cobertura geográfica homogénea y representativa de la totalidad del territorio de cada Estado miembro con el fin de garantizar la coherencia y el equilibrio de la red que de ellos resulte; $3^{\circ}$ ) La lista debe ser completa, es decir, cada Estado miembro debe proponer un número de lugares que permita incluir de manera suficientemente representativa todos los tipos de hábitat naturales mencionados en los anexos de la Directiva 92/43. Como afirma el profesor López Vera el TJUE ha insistido en el carácter completo de la información de que debe disponer la Comisión procedente de cada Estado miembro, para poder decidir con criterios representativos sobre el listado de lugares de interés comunitario en el conjunto de Europa (STJUE de 11 de febrero de 2001 (C-67/99, 71/99 y 220/99, Comisión contra Irlanda, Alemania y Francia), 7 de noviembre de 2000, First Corporate Shipping (C-371/98), 14 de septiembre de 2006 (C-244/05, Bund Naturschutz in Bayern)). Desde este modo, en la última de las sentencias citadas el TJUE afirma que: “... un Estado miembro no dispone, cuando elabora la 
lista nacional de lugares, de un conocimiento preciso y detallado de la situación de los hábitats en los demás Estados miembros, no puede, por sí solo, excluir lugares que posean a nivel nacional un interés ecológico pertinente para el objetivo de conservación, sin poner en peligro la consecución de este mismo objetivo en el ámbito comunitario. Por consiguiente, la Comisión debe tener la seguridad de contar con un inventario exhaustivo de los lugares que pueden ser designados zonas especiales de conservación, ya que la constitución de éstas tiene como objetivo una red ecológica europea coherente. De ello se desprende asimismo que, en el momento de adoptar su decisión la Comisión, los lugares identificados por los Estados miembros deben reflejar la situación en la que se basaron las evaluaciones cientificas relativas a los potenciales lugares de importancia comunitaria. ${ }^{19}$

Esta doctrina jurisprudencial confirma una aplicabilidad restrictiva de las excepciones previstas en la Directiva para reducir los espacios protegidos con finalidades distintas a las protectoras [SSTJUE de 28 de febrero de 1991 (C-57/89 Comisión contra Alemania), o de 11 de julio de 1996 (C-44/95 Regina)]. Esta conclusión debe ser tenida muy en cuenta en el momento actual, cuando España ha sido condenada recientemente por STJUE de 28 de junio de 2007 (C-C-235/04, Comisión contra España) por el incumplimiento de sus obligaciones en la declaración

${ }^{19}$ De igual modo, se hace imprescindible destacar la idea de que un Estado miembro "no puede, por sí solo, excluir lugares que posean a nivel nacional un interés ecológico pertinente para el objetivo de conservación". Por ese mismo motivo, y con más razón, una vez que ese espacio ha sido incorporado en el listado comunitario de LIC, los Estados miembros tienen la obligación de adoptar medidas de protección apropiadas para mantener las características ecológicas de dichos lugares. Pues bien, entre esas obligaciones la STJUE de 14 de septiembre de 2006 (C-244/05, Bund Naturschutz in Bayern) señala que los Estados miembros no pueden "autorizar intervenciones que puedan alterar significativamente las características ecológicas de un lugar tal como lo definen dichos criterios. Así ocurre, en particular, cuando una intervención conlleva el riesgo de reducir de forma significativa la superficie del lugar, o de provocar la desaparición de especies prioritarias existentes en él, o, por último, de tener como resultado la destrucción del lugar o la eliminación de sus características representativas". Esta jurisprudencia del TJUE en relación con la imposibilidad de reducir o destruir parcialmente la superficie declarada como LIC es semejante a la jurisprudencia del TJUE en el marco de la delimitación y reducción de ZEPAS. Desde este punto de vista, el TJUE mantiene una doctrina muy estricta sobre el margen de apreciación de que gozan los Estados miembros para reducir los espacios así declarados (López, 2009). La STJUE de 28 de febrero de 1991 (C-57/89, Comisión contra Alemania) afirma que "los Estados miembros disponen de cierto margen de apreciación al escoger los territorios más apropiados para clasificarlos como zonas de protección especial, de acuerdo con el apartado 1 del art. 4 de la Directiva, por el contrario no pueden disponer del mismo margen de apreciación en el ámbito del apartado 4 del art. 4 de la Directiva, para modificar o reducir la superficie de dichas zonas, ya que ellos mismos reconocieron en sus declaraciones que dichas zonas reúnen las condiciones de vida más apropiadas para las especies enumeradas en el anexo I de la Directiva. obligaciones que les impone el apartado 4 del art. 4 de la Directiva en materia de zonas de protección especial". 
de espacios de la Red Natura 2000, en concreto, al no haber clasificado como zonas de protección especial territorios suficientes en superficie para ofrecer una protección a todas las especies protegidas por las Directivas comunitarias. Este alegato tiene más sentido si cabe, si tenemos en cuenta los muchos procedimientos abiertos contra España por la Comisión Europea por incumplimiento de sus obligaciones en supuestos idénticos a los relatados y al que ahora es objeto de nuestro Dictamen. Estos datos, y otros muchos más, se ponen igualmente de relieve en el informe de los parlamentarios europeos Marcin Libicki y Michael Cashman, sobre la misión de investigación en Madrid, la Comunidad Valenciana y Andalucía del 27 de febrero al 3 de marzo de 2007 (López, 2009). Las previsiones del Derecho comunitario y de la jurisprudencia del TJUE comentadas han tenido su acogida en nuestro Derecho positivo. Debemos recordar en este sentido que la Ley 8/2007, y luego el TRLS de 2008, han previsto en el apartado $4^{\circ}$ del art. 13 de ambos textos legales, lo que sin duda es uno de los preceptos más importantes de la nueva legislación de suelo: "No obstante lo dispuesto en los apartados anteriores, la utilización de los terrenos con valores ambientales, culturales, históricos, arqueológicos, cientificos y paisajísticos que sean objeto de protección por la legislación aplicable, quedará siempre sometida a la preservación de dichos valores, y comprenderá únicamente los actos de alteración del estado natural de los terrenos que aquella legislación expresamente autorice. Sólo podrá alterarse la delimitación de los espacios naturales protegidos o de los espacios incluidos en la Red Natura 2000, reduciendo su superficie total o excluyendo terrenos de los mismos, cuando así lo justifiquen los cambios provocados en ellos por su evolución natural, científicamente demostrada. La alteración deberá someterse a información pública, que en el caso de la Red Natura 2000 se hará de forma previa a la remisión de la propuesta de descatalogación a la Comisión Europea y la aceptación por ésta de tal descatalogación". La claridad de las determinaciones legales ha sido posteriormente reiterada por el ya comentado art. 51 de la Ley 42/2007 de patrimonio natural y de la biodiversidad: "1. Sólo podrá alterarse la delimitación de espacios naturales protegidos o de la Red Natura 2000, reduciendo su superficie total o excluyendo terrenos de los mismos, cuando asi lo justifiquen los cambios provocados en ellos por su evolución natural, cientificamente demostrada. En el caso de alteraciones en las delimitaciones de espacios protegidos Red Natura 2000, los cambios debidos a la evolución natural deberán aparecer debidamente reflejados en los resultados del seguimiento previsto en el artículo 47. 2. Toda alteración de la delimitación de áreas protegidas deberá someterse a información pública, que en el caso de los espacios protegidos Red Natura 2000 se hará de forma previa a la remisión de la propuesta de descatalogación a la Comisión Europea y la aceptación por ésta de tal descatalogación. 3. El cumplimiento de lo previsto en los párrafos anteriores no eximirá de las normas adicionales de protección que establezcan las Comunidades autónomas". En definitiva, dos cuerpos legales vigentes establecen el siguiente procedimiento para alterar la delimitación declarada de los espacios de la Red Natura 2000 reduciendo su superficie total o excluyendo terrenos: $1^{\circ}$ ) Debe estar justificado por los cambios provocados en ellos 
por su evolución natural, científicamente demostrada. Esto significa que sólo con un estudio basado en datos científicos es posible tratar de justificar que un espacio protegido ha perdido sus condiciones naturales. Además, es preciso que dicho estudio demuestre esa nueva situación debido a la "evolución natural" del hábitat y no gracias a actuaciones externas (generalmente obra del hombre). $2^{\circ}$ ) Además, en el caso de alteraciones en las delimitaciones de espacios protegidos Red Natura 2000, los cambios debidos a la "evolución natural" deberán aparecer debidamente reflejados en los resultados del seguimiento previsto en el art. 47 de la Ley 42/2007: "Las Comunidades Autónomas vigilarán el estado de conservación de los tipos de hábitats y las especies de interés comunitario, teniendo especialmente en cuenta los tipos de hábitats naturales prioritarios y las especies prioritarias, así como de conservación de las especies de aves que se enumeran en el anexo $\mathrm{IV}$, comunicando al Ministerio de Medio Ambiente los cambios que se hayan producido en los mismos a efectos de su reflejo en el Inventario Español del Patrimonio Natural y de la Biodiversidad. Dicha comunicación se producirá anualmente excepto cuando ello no sea técnicamente posible, en cuyo caso deberá argumentarse. Las Comunidades Autónomas remitirán al Ministerio de Medio Ambiente información sobre las medidas de conservación a las que se refiere el artículo 45.1, la evaluación de sus resultados y las propuestas de nuevas medidas a aplicar, al objeto de que el Ministerio pueda remitir a la Comisión Europea, cada tres y seis años respectivamente, los informes nacionales exigidos por las Directivas comunitarias 79/409/CEE y 92/43/CE reguladoras de las zonas de la Red Natura 2000”. En otras palabras, no es sólo que la evolución natural de los espacios protegidos deba estar fundamentada debidamente en datos científicos, sino que además esa evolución debe deducirse y plasmarse en los informes que deben preparar las CCAA cada año, poniendo en evidencia una "evolución natural" del hábitat protegido que refleje que está perdiendo sus condiciones naturales. $3^{\circ}$ ) La alteración pretendida deberá someterse a información pública antes de la remisión de la propuesta de descatalogación a la Comisión Europea. Además, la reducción o redelimitación en todo caso depende de la aceptación por la Comisión de la propuesta sometida a información pública (Observatorio de la Sostenibilidad, 2008).

\subsection{LEGISLACIÓN Y NORMATIVA DE ÁMBITO REGIONAL}

Tras la aprobación de los Estatutos de Autonomía (Ley Orgánica 9/1982), dos de los principales retos políticos han sido la construcción de la identidad regional y la definición de un modelo territorial propio, que van tomando forma mediante el desarrollo de las competencias que otorga la Constitución Española (Emid, 2010). A la vista del progreso de una de estas competencias (la Ordenación del Territorio y el Urbanismo), podemos afirmar que el modelo espacial ha dependido básicamente de las políticas sectoriales y de Desarrollo Regional hasta el momento actual. La Ordenación del Territorio se ha visto subordinada y su aplicación se explica como una actitud reactiva para resolver la articulación del sistema urbano, facilitar la competitividad territorial y garantizar los valores naturales y patrimoniales, además 
de corregir los conflictos, tensiones e impactos ambientales surgidos por la ausencia de un modelo de planificación integrada. Esta idea conduce a pensar también que la Ordenación del Territorio alcanza su protagonismo y madurez después de un proceso de aprendizaje del sistema de gobernanza, paralelo a la aplicación de las políticas comunitarias (Plaza Tabasco et alii, 2011).

La sentencia del Tribunal Constitucional 61/1997 provocó que comunidades como Castilla La Mancha, que nos puede servir como ejemplo, iniciaran su andadura en esta materia mediante la Ley 2/1998, de 4 de junio, de Ordenación del Territorio y la Actividad Urbanística (LOTAU), en la que destaca el marcado perfil urbanístico, en detrimento de una visión más territorial (Plaza, 2003).

Todo el análisis desarrollado resulta del siguiente escenario legislativo: Competencias exclusivas de las Comunidades Autónomas. Y, es que, las Comunidades Autónomas tienen competencias exclusivas en materia de Ordenación del Territorio, Urbanismo y Vivienda, lo que supone diferentes normativas sobre estas materias. Los contenidos urbanísticos que se regulan en las Leyes de Suelo de las Comunidades Autónomas, son de aplicación sólo en el ámbito de la Comunidad Autónoma correspondiente (Emid, 2010). Cada Ley de suelo autonómica no agota por sí sola la regulación en su ámbito y exige un adecuado desarrollo reglamentario de protección de la legalidad urbanística, la planificación urbana del uso del suelo y su regulación técnico-jurídica. Progresivamente se han publicado reglamentos, decretos e instrucciones (10 de 17 Comunidades autónomas cuentan con desarrollo reglamentario).

Las leyes autonómicas están encuadradas en un ámbito definido por una Legislación General o Estatal. Esta norma tiene carácter básico y sólo establece una serie de principios generales; limitándose a regular las condiciones básicas del ejercicio del derecho de propiedad, las garantías generales de la expropiación forzosa y el régimen de valoraciones del suelo, las responsabilidades patrimoniales de la Administración y algunos aspectos registrales (Emid, 2010). Se trata del RDL 2/2008, de 20 de junio, que aprueba el texto refundido de la Ley de Suelo, de la que recientemente se ha aprobado el Reglamento de Valoraciones RD 1492/2011, de 24 de octubre. Su aprobación supone la derogación de todo el título IV Valoraciones del RD 3288/1978, 25 de agosto, Reglamento de Disciplina Urbanística, al que se hace alusión en el punto siguiente. Normativas estatales de carácter supletorio Perviven una serie de normativas estatales de carácter supletorio, que son de aplicación en aquellos puntos no desarrollados en las Leyes urbanísticas y Reglamentos de cada Comunidad Autónoma, siempre que no se opongan a los mismos. Se trata del Real Decreto 1346/76, de 9 de Abril, por el que se aprueba el Texto Refundido de la Ley sobre Régimen del Suelo y Ordenación Urbana (1) y sus Reglamentos de desarrollo (2) en los artículos que no han sido derogados por el RD 304/93:

a) El Real Decreto 2159/78, de 23 de junio. Reglamento de planeamiento urbanístico. 
b) El Real Decreto 3288/78, de 25 de agosto. Reglamento de disciplina urbanística.

c) El Real Decreto 2187/78, de 23 de junio. Reglamento de disciplina urbanística.

Básicamente en todas las Comunidades Autónomas se ha seguido el modelo inicial del urbanismo definido en la legislación estatal, de manera que se han mantenido el Planeamiento, la Gestión Urbanística y la Disciplina Urbanística, entendidas estas tal y como se recoge en el documento titulado "Legislación Urbanística Estatal y Autonómica", como;

a) Planeamiento: Es el conjunto de instrumentos o planes destinados a organizar y controlar el tejido urbano existente y su desarrollo, y la clasificación del suelo, como la técnica para fijar diferentes categorías del suelo en función de su destino urbanístico básico.

b) Podría definirse como el conjunto de actuaciones que es necesario realizar para el desarrollo e implantación en el territorio de las determinaciones Establecidas en el planeamiento. Tiene por objeto concretar las tareas de los diferentes actores en el proceso de transformación del suelo: administraciones públicas, propietarios, urbanizadores y promotores.

c) La Disciplina Urbanística, como el conjunto de previsiones legales y potestades administrativas previstas para controlar la adaptación entre el uso del suelo y la edificación y la legislación y el planeamiento urbanístico vigente.

Por otra parte, no debemos olvidarnos que en las últimas décadas, España ha vivido lo que Antonio Font Arellano denomina la "explosión de la ciudad" ${ }^{20}$. Esta "explosión" viene marcada por la dispersión por el territorio de zonas residenciales, de actividades económicas secundarias y terciaras, por el flujo de personas y mercancías, que demandan y disponen nuevos usos del suelo; y que, a posteriori, definen y marcan nuevas morfologías espaciales que se traducen en nuevos modelos de "creación de ciudad". Estas transformaciones territoriales han sido consecuencia directa del incremento de la población en áreas cada vez más alejadas de los núcleos urbanos, favoreciendo la "densificación" de zonas urbanas dispersas, lo que ha propiciado un proceso de descentralización económica y política. De este modo, se ha generalizado la difusión de actividades productivas terciarias e industriales en las periferias de las ciudades, se ha incrementado el flujo de personas y mercancías como consecuencia de la descentralización entre empleo, servicios y residencia-, han

\footnotetext{
${ }^{20}$ FONT ARELANO, A. (2006): "La explosión de la ciudad: transformaciones territoriales en las regiones urbanas de la Europa Meridional”, Ministerio de Vivienda, 84-96387-25-9
} 
favorecido el surgimiento de nuevos cetros de terciario y incidiendo, directa e indirectamente, en nuevas centralidades urbanos -normalmente, localizados en los bordes de granes vías de comunicación-, entre otros. Y, como consecuencia principal de dichos cambios o transformaciones territoriales, los nuevos centros urbanos están definidos y orientados por la capacidad de dirección de la economía, de la información, de las comunicaciones y del conocimiento con lo que, lejos de ser dependientes, lo que hacen es crear nuevas centralidades a la par que nuevas necesidades; todo ello sin olvidarnos de la perdida de espacios naturales, la desprotección del medio ambiente y la falta de conservación de la naturaleza. En definitiva, nos encontramos ante nuevas formas de hacer ciudad en las que la especialización espacial, la recalificación urbana, la dispersión en el territorio o la reorganización productiva han creado y crean nuevas formas de vida urbana y de los instrumentos de planeamiento e intervención en el territorio. Con todo ello, como instrumento de planeamiento destaca la presente Ley del Suelo 2/2008, que tiene como objeto la optimización de la prestación de servicios, la protección ambiental, la colaboración interinstitucional y el establecimiento ${ }^{21}$ de instrumentos de mejora de la

${ }^{21}$ TRLS 2/2008, Artículo 2. Principio de desarrollo territorial y urbano sostenible.

1. Las políticas públicas relativas a la regulación, ordenación, ocupación, transformación y uso del suelo tienen como fin común la utilización de este recurso conforme al interés general y según el principio de desarrollo sostenible, sin perjuicio de los fines específicos que les atribuyan las Leyes.

2. En virtud del principio de desarrollo sostenible, las políticas a que se refiere el apartado anterior deben propiciar el uso racional de los recursos naturales armonizando los requerimientos de la economía, el empleo, la cohesión social, la igualdad de trato y de oportunidades, la salud y la seguridad de las personas y la protección del medio ambiente, contribuyendo en particular a:

a) La eficacia de las medidas de conservación y mejora de la naturaleza, la flora y la fauna y de la protección del patrimonio cultural y del paisaje.

b) La protección, adecuada a su carácter, del medio rural y la preservación de los valores del suelo innecesario o inidóneo para atender las necesidades de transformación urbanística.

c) La prevención adecuada de riesgos y peligros para la seguridad y la salud públicas y la eliminación efectiva de las perturbaciones de ambas.

d) La prevención y minimización, en la mayor medida posible, de la contaminación del aire, el agua, el suelo y el subsuelo.

3. Además de lo dispuesto en el apartado anterior, los poderes públicos propiciarán la consecución de un medio urbano que esté suficientemente dotado, en el que se ocupe el suelo de manera eficiente, y en el que se combinen los usos de forma funcional, garantizando, en particular:

a) La movilidad en coste y tiempo razonable, sobre la base de un adecuado equilibrio entre todos los sistemas de transporte, que, no obstante, otorgue preferencia al transporte público y colectivo y potencie los desplazamientos peatonales y en bicicleta.

b) La accesibilidad universal, de acuerdo con los requerimientos legales mínimos, de los edificios de uso privado y público, de los espacios de uso público y de los transportes públicos. 
competencia de las administraciones y los gobiernos locales con el fin de optimizar el acceso, el uso y el disfrute de los servicios -tanto públicos como privados-. De este modo, instrumentos de planificación como el que hemos llevado a estudio, tienen como fin -o así debería ser-, la optimización y el uso eficiente del recurso suelo ${ }^{22}$, mediante una optima estructuración y reestructuración del urbanismo, con la correcta dotación y creación de infraestructuras -fundamentalmente de transporte y comunicación- que eliminen las costosas congestiones -en términos económicos y ecológicos-, redes telemáticas para el flujo de informaciones y conocimientos, nuevas formas urbanas que hagan posible la existencia del transporte colectivo, el uso más racional de recursos naturales escasos -por parte de las instituciones y de los ciudadanos $^{23}$-, la localización de actividades productivas y la instalación de los

c) El uso eficiente de los recursos y de la energía, preferentemente de generación propia, así como la introducción de energías renovables.

d) La prevención y, en todo caso, la minimización en la mayor medida posible, por aplicación de todos los sistemas y procedimientos legalmente previstos, de los impactos negativos de los residuos urbanos y de la contaminación acústica.

La persecución de estos fines se adaptará a las peculiaridades que resulten del modelo territorial adoptado en cada caso por los poderes públicos competentes en materia de ordenación territorial y urbanística.

4. Los poderes públicos promoverán las condiciones para que los derechos y deberes de los ciudadanos establecidos en los artículos siguientes sean reales y efectivos, adoptando las medidas de ordenación territorial y urbanística que procedan para asegurar un resultado equilibrado, favoreciendo o conteniendo, según proceda, los procesos de ocupación y transformación del suelo.

El suelo vinculado a un uso residencial por la ordenación territorial y urbanística está al servicio de la efectividad del derecho a disfrutar de una vivienda digna y adecuada, en los términos que disponga la legislación en la materia.

${ }^{22}$ TRLS 2/2008, artículo 4. Derechos del ciudadano.

Todos los ciudadanos tienen derecho a:

a) Disfrutar de una vivienda digna, adecuada y accesible, concebida con arreglo al principio de diseño para todas las personas, que constituya su domicilio libre de ruido u otras inmisiones contaminantes de cualquier tipo que superen los límites máximos admitidos por la legislación aplicable y en un medio ambiente y un paisaje adecuados.

${ }^{23}$ TRLS 2/2008, artículo 5. Deberes del ciudadano.

Todos los ciudadanos tienen el deber de:

a) Respetar y contribuir a preservar el medio ambiente y el paisaje natural absteniéndose de realizar actuaciones que contaminen el aire, el agua, el suelo y el subsuelo o no permitidas por la legislación en la materia.

b) Cumplir los requisitos y condiciones a que la legislación sujete las actividades molestas, insalubres, nocivas y peligrosas, así como emplear en ellas en cada momento las mejores técnicas disponibles conforme a la normativa aplicable, encaminadas a eliminar o reducir los efectos negativos señalados.

c) Respetar y hacer un uso racional y adecuado, acorde en todo caso con sus características, función y capacidad de servicio, de los bienes de dominio público y de las infraestructuras y los servicios urbanos. 
equipamientos ambientales necesarios para el uso eficiente de los recursos hídricos y que permitan la correcta eliminación de residuos. Puesto que, hoy día, la regeneración urbana no es una opción política a la transformación del suelo rural mediante obras de urbanización, sino una exigencia del principio de desarrollo territorial y urbano sostenible recogido en la vigente Ley estatal de Suelo (Texto Refundido la Ley del Suelo 2/2008) e implícito en la Constitución ${ }^{24}$. La citada Ley establece que las políticas urbanas se deben basar en la regeneración y mejora de los tejidos existentes y no en nuevas ocupaciones de suelo. En la propia Ley el concepto de actuaciones de urbanización comprende tanto las actuaciones de reforma o renovación del suelo ya urbanizado como las de primera transformación del suelo rural, si bien estas últimas en lo sucesivo deberían ser, si no excepcionales, sí, el menos, suficientemente justificadas. Como señala el preámbulo de la citada Ley "el crecimiento urbano sigue siendo necesario, pero hoy parece asimismo claro que el urbanismo debe responder a los requerimientos de un desarrollo sostenible, minimizando el impacto de aquel crecimiento y apostando por la regeneración de la ciudad existente".

A tenor de todo lo expuesto, se hace imprescindible realizar un estudio pormenorizado de la estrecha vinculación existente entre la actual Ley del Suelo y el Medio Ambiente, ahondando, posteriormente, en la instrumentación económica recogida en la misma, con el fin de prevenir, proteger, conservar y restaurar un recurso natural de gran valor como es el suelo, en nuestro país.

Antes de continuar con el tratamiento de la Ley del Suelo de notable valor se presenta, como un breve paréntesis, tratar del "Estatuto del suelo de titularidad pública". La titularizad Pública de los bienes, como es bien sabido no se rige por las mismas normas que disciplinan la propiedad privada. La legislación de patrimonio regula la adquisición, régimen jurídico y extinción de los bienes públicos, dentro de los cuales, los bienes de dominio público tienen a su vez un estatuto especial en razón de la utilidad de los mismos. No es lo mismo el régimen del dominio público

d) Respetar y contribuir a preservar el paisaje urbano y el patrimonio arquitectónico y cultural absteniéndose en todo caso de realizar cualquier acto o desarrollar cualquier actividad no permitidos.

${ }^{24}$ Constitución Española, artículo 45:

1. Todos tienen el derecho a disfrutar de un medio ambiente adecuado para el desarrollo de la persona, así como el deber de conservarlo.

2. Los poderes públicos velarán por la utilización racional de todos los recursos naturales, con el fin de proteger y mejorar la calidad de la vida y defender y restaurar el medio ambiente, apoyándose en la indispensable solidaridad colectiva.

Constitución Española, artículo 46: Los poderes públicos garantizarán la conservación y promoverán el enriquecimiento del patrimonio histórico, cultural y artístico de los pueblos de España y de los bienes que lo integran, cualquiera que sea su régimen jurídico y su titularidad. La ley penal sancionará los atentados contra este patrimonio. 
marítimo-terrestre, que el de las aguas continentales, ni el de estos dos tiene nada que ver con el llamado espectro radio-eléctrico. Pues bien: el suelo como bien susceptible de titularidad pública también goza en el ordenamiento de un estatuto especial que no es equiparable al privado. Como en todo el Derecho Administrativo, la Administración como titular del suelo goza de ciertas prerrogativas y de ciertas obligaciones no comparables a las del privado. Dentro a su vez del estatuto público del suelo, el régimen jurídico de los bienes públicos es diferente según se trate de bienes de titularidad municipal o bienes de los que son titulares otras Administraciones Públicas, como el Estado o las Comunidades Autónomas. Cabe a este respecto establecer un summa divissio entre el régimen de los suelos municipales y el de las restantes Administraciones Públicas. Estas últimas se rigen por la legislación patrimonial pública, de modo que en cada caso según se trate de bienes de dominio público (por ejemplo, carreteras) o bienes patrimoniales, se aplicará la legislación correspondiente. Conviene notar, a efectos urbanísticos, hecho frecuentemente ignorado por aparentemente irrelevante, que todas las Administraciones Públicas, salvo la municipal, no tienen más limitaciones específicas que las derivadas del régimen general aplicable por la naturaleza de bienes. Si son bienes de dominio público estarán afectos al fin que justifica su carácter de tales; si son bienes patrimoniales, la Administración titular tendrá urbanísticamente los mismos derechos y deberes de los propietarios privados. Sin embargo, los suelos de titularidad municipal de carácter patrimonial quedan afectos al patrimonio municipal de suelo al igual que los suelos edificables provenientes de las cesiones de aprovechamiento ya estudiadas. Este dualismo de tratamiento, que tiene su origen en el Reglamento de Bienes de las Corporaciones Locales de 27 de mayo de 1955, es la causa, a nuestro juicio, de algunos malentendidos que pesan sobre esa borrosa institución, que se llama patrimonio público del suelo. ${ }^{25}$

${ }^{25}$ Desde la perspectiva del Derecho estatal supletorio, frente a los suelos de titularidad municipal, los restantes suelos públicos carecen de un régimen de vinculación o destino diferente del que tengan según su particular estatuto.

En el Derecho estatal y en el de las Comunidades Autónomas, los bienes de titularidad del Estado y de las Comunidades Autónomas afectados por una ordenación urbanística se regulaban por la legislación urbanística. Salvo que en el ejercicio de su específica competencia fuera necesario modificar el plan, conforme al art.180.2 TRLS 1976.

$\mathrm{El}$ art.47 n 2 y 3 RGU establece el siguiente régimen jurídico.

1) El suelo destinado a uso público y el destinado a edificación o instalaciones de servicio público no podrán cambiar de finalidad, sin modificar el plan.

2) Cuando las superficies de los bienes de dominio y uso públicos anteriormente existentes fueran iguales o inferiores a las que resultan del nuevo plan, las superficies se sustituyen unas por otras, sin que la Administración pueda participar en el reparto de beneficios y cargas, ya que -se entiende-esas superficies fueron obtenidas en su día mediante una cesión gratuita.

Conforme a estos preceptos cabía distinguir: A) Inmuebles del Estado o cualquier ente público cuyo destino en el Plan es precisamente un servicio o finalidad pública, mientras se mantenga 
Desde la perspectiva del régimen urbanístico en la legislación de patrimonio del Estado. Subrayar que la Ley del Suelo del 2007 destaca en el art. 190 bis, que cuando "los instrumentos de ordenación territorial y urbanística incluyan en el ámbito de las actuaciones de urbanización o adscriban a ellas terrenos afectados o destinados a usos y servicios públicos de competencia estatal, la Administración General del Estado o los organismos públicos titulares de los mismos que los hayan adquirido por expropiación y otra forma onerosa participarán en la equidistribución de beneficios y cargas en los términos que establezca la legislación sobre ordenación territorial y urbanística" ${ }^{26} \mathrm{Y}$ es que, si bien la finalidad que puede perseguir el Estado es lógica

esa calificación, no pueden intervenir en operaciones de distribución de beneficios y cargas, toda vez que tal intervención sería contradictoria con su finalidad pública. B) Inmuebles obtenidos por antiguas cesiones de los propietarios para uso público (viales, zonas verdes, etc.) su inclusión en una operación de reforma interior o de mejora urbanística, no significa que el ayuntamiento deba participar en el reparto de beneficios y cargas. La explicación es el siguiente: si ya existen terrenos públicos destinados a viales y a otros usos públicos es porque en el pasado los propietarios los cedieron al Ayuntamiento o, en casos históricos, porque siempre fueron de uso público. En esa medida, no deben obtenerse de nuevo gravando a los propietarios con cesiones innecesarias.

La excepción la encontramos en el supuesto de que las nuevas superficies de los estándares de planeamiento sean inferiores a las antiguas. En este caso el exceso se considera como un bien patrimonial de la Administración, por el cual recibirá como cualquier propietario privado la superficie edificable que le corresponda, participando en las obligaciones urbanísticas en la misma proporción que los propietarios privados.

Algunos pronunciamientos judiciales (SSTS de 30 de junio de 1982 y de 7 de marzo de 1987; STSJCV de 24 de diciembre de 2003) sostienen que el principio de sustitución de las parcelas de uso público sólo juega en el caso de operaciones de reforma interior o de transformaciones del suelo urbano no consolidado. Se arguye, no sin razón, que los caminos o demás bienes de titularidad municipal provenientes de suelo rural deben participar en la distribución de beneficios y cargas, pues de lo contrario se limitan o reducen las cesiones obligatorias de los particulares en perjuicio del común. El art.47 RGU debe interpretarse en el sentido, pues, de que sólo regirá el principio de sustitución de las parcelas públicas cuando aquellas sean consecuencia de cesiones urbanísticas anteriores gratuitas, pero no cuando su adquisición sea consecuencia de una expropiación o pertenezcan a la hacienda pública por otro título, sea oneroso o gratuito.

${ }^{26}$ Luciano Parejo $(2008,525)$ subraya que el precepto pretende asegurar la participación del Estado en las plusvalías urbanísticas respecto de los bienes de dominio público, como ya lo hace el art. 190.2 de la misma ley respecto de los patrimoniales: «Es notorio -dice Parejo- que los ámbitos de los nuevos desarrollos urbanísticos de ordenan en torno a estas infraestructuras y servicios estatales, de los que sacan provecho. Sin embargo, también es habitual que el Estado costee la obtención del suelo y la ejecución de la infraestructura y no participe de la plusvalía urbanística generada gracias a ella en su entorno inmediato».

Aunque esta explicación es razonable, el precepto plantea algunas cuestiones oscuras. La competencia del Estado para dictar esta normativa dista de estar clara. Parece difícil incluir el texto legal dentro de la competencia patrimonial, ya que no está en juego la protección o el régimen del dominio, sino exclusivamente el alcance del principio de equitativa distribución del beneficio y cargas, que es cuestión esencialmente urbanística. 
(que los bienes estatales se beneficien de la plusvalía que ellos mismos han ayudado a generar), resulta muy discutible la competencia estatal. Se trata de una materia indudablemente urbanística, pues de lo que se ocupa el art. 190 bis es de la inclusión de terrenos a efectos "reparcelatorios".

Por otro lado, en gran parte, el precepto es superfluo. El supuesto de hecho es que la ordenación urbanística incluya en un ámbito terrenos de dominio público estatal o los adscriba a efectos de gestión, Bastará, pues, con no incluir a un terreno público en un determinado ámbito para excluir al dominio público estatal de la distribución equitativa de beneficios y cargas. El asunto no puede resolverse mediante un precepto para el que el Estado carece de competencias, sino por aplicación pura y simple de las reglas generales de domino público ${ }^{27}$. Si un bien de dominio público se incluye en un

Debe observarse también que esta norma no alcanza exclusivamente al Estado sino a los demás entes públicos. Conforme a la Disposición final segunda, el precepto es básico. El artículo utilizado por el Estado es el 149.1.18. ${ }^{\mathrm{a}} \mathrm{CE}$, según se desprende de la Disposición fiscal primera del TRLS 2008.

Finalmente, el precepto interpretado literalmente, puede llevar a la inconsecuencia de que terrenos de domino público adquiridos en su día a título gratuito (por ejemplo, una donación) por razones completamente ajenas a las cesiones urbanísticas, no participen en el reparto de plusvalías, sin que exista razón alguna para ello. Como ya explicamos más atrás, la jurisprudencia excluía del reparto de beneficios y cargas a aquellos terrenos que hubieran sido cedidos por razones urbanísticas con anterioridad: de lo contrario - dice el Tribunal Supremopodría llegarse al absurdo de una eliminación de los derechos de los propietarios por la sucesión de cesiones en el tiempo. Lo cual nada tiene que ver con el caso de las donaciones voluntarias extraurbanísticas.

${ }^{27}$ Podemos imaginarnos un caso en que un instituto público de investigación situado en un área reparcelable sigue manteniendo el mismo destino. Lo lógico es que no participe en la reparcelación ni con beneficios ni con cargas. No es lo mismo, sin embargo, en el caso de que la Administración del Estado decida desafectar el terreno, pues entonces como otro propietario más, debería participar en la reparcelación. Obsérvese, además, que la Administración urbanística no podría imponer el cambio de calificación del terreno del instituto, sin contar con la aquiescencia del Estado, puesto que la Administración urbanística no se puede superponer jerárquicamente al Estado, cuando éste actúa en ejercicio de sus competencias; es decir, lo capital no es el régimen urbanístico, sino la afectación o desafectación del inmueble al uso o servicio público. Por otra parte señalar que aunque no hay en la doctrina una elaboración sistemática del régimen urbanístico de los suelos públicos, nos parece imprescindible ensayar esta sistematización, para poder comprender mayor la mayor o menos relación que el suelo tiene respecto de la financiación y los servicios locales. Y es que de la misma forma que hay un estatuto de la propiedad privada del suelo, por razones semejantes puede hablarse también de un estatuto de la propiedad pública del suelo, o por mejor decir, de la propiedad municipal del suelo, pues son los municipios los destinatarios principales de las reglas urbanísticas. Debemos distinguir entonces por el modo de adquisición entre cesiones de suelo para dotaciones o infraestructuras públicas; cesiones de suelo edificable y adquisiciones por expropiación, destacando las cesiones de suelo para dotaciones públicas. Estas cesiones implican la aplicación del régimen del dominio público, ya sea porque se trate de bienes de uso público (viales, jardines, etc.), ya sea porque se trate de infraestructuras necesarias para instalar servicios públicos (centros educativos, deportivos, etc.) Resulta lógico que estos 
ámbito urbanístico y mantiene en el plan la misma calificación que determinó su afectación al uso o al servicio público, carece de sentido que la norma imponga la participación de ese dominio público en el reparto equitativo de beneficios y cargas. Procederá o no ese reparto en función de las circunstancias concurrentes y de la voluntad concordante de la Administración del dominio público y de la urbanística.

\subsubsection{UN ESTUDIO DE CASO: DESARROLLO, MEDIO AMBIENTE Y TERRITORIO EN EL REAL DECRETO LEGISLATIVO 2/2008}

Uno de los puntos principales del Texto Refundido de la Ley del Suelo 2/2008, no existente en las leyes del suelo anteriores, es la incorporación de las nuevas bases ambientales de sostenibilidad en la ordenación y utilización del suelo, establecidas por la política de la Unión Europea. De hecho, en la "Exposición de Motivos" de la presente Ley se hace regencia a la Comunicación de la Comisión Europea sobre una Estrategia Temática para el Medio Ambiente Urbano en la que se propone "un modelo de ciudad compacta y advierte de los graves inconvenientes de la urbanización dispersa o desordenada: impacto ambiental, segregación social e ineficiencia económica por los elevados costes energéticos, de construcción y mantenimiento de infraestructuras y de prestación de los servicios públicos. El suelo,

terrenos queden vinculados al fin que justifica su cesión. Su desafectación queda limitada por motivos urbanísticos. Con independencia de la necesidad de modificar el plan previamente a la desafectación, aquí juegan también los estándares urbanísticos, de modo que en ningún caso la desafectación puede ir en detrimento de las pautas mínimas establecidas en los planes. Algunas leyes autonómicas permiten que estos terrenos rotacionales integren el patrimonio municipal de suelo. Esto no tiene más efecto que limitar, en caso de desafectación, las posibilidades del Ayuntamiento a la hora de enajenar el bien. Mayor interés reviste el especial régimen que desde la LS 2007 tiene el subsuelo y el vuelo de los suelos dotaciones públicos. La ley dota a los municipios de un régimen privilegiado que le permite segregar el subsuelo o el suelo de un terreno rotacional y explotarlo económicamente o enajenarlo, siempre que sea compatible la segregación con el destino rotacional. Dice el art. 17.4 TRLS 2008: "Cuando, de conformidad con lo previsto en su legislación reguladora, los instrumentos de ordenación urbanística destinen superficies superpuestas, en la rasante y el subsuelo o el vuelo, a la edificación o uso privativo y al dominio público, podrá constituirse complejo inmobiliario en el que aquéllas y ésta tengan el carácter de fincas especiales de atribución privativa, previa la desafectación y con las limitaciones y servidumbres que procedan para la protección del dominio público". Ciertamente, en la práctica el Tribunal Supremo había venido admitiendo que los subsuelos de jardines y plazas se explotaran por los Ayuntamientos como concesiones administrativas, sin que sugiera derecho de reversión de los propietarios en su día expropiados para obtener dichos suelos rotacionales. Según la jurisprudencia, el Código Civil daba bastante cobertura a esa explotación, en la medida en que el dueño del suelo lo es también del subsuelo. 
además de un recurso económico, es también un recurso natural, escaso y no renovable".

Si bien, debemos señalar que en materia de instrumentación económica en materia de gestión ambiental, la Ley carece casi por completo de competencia ${ }^{28}$; lo que limita las capacidades de actuación, provocando así que las buenas praxis recogidas en la "Exposición de Motivos" y en el "Título Preliminar" de dicha Ley quede limitadas, o condicionadas, por otras legislaciones. A pesar todo, la Ley aporta una serie de propuestas concretas y concisas sobre la actuación en la conservación y preservación -que no en la regeneración- del medio natural y, por ende, del suelo, sobre el que se asientan tanto los edificios e infraestructuras como las actividades socioeconómicas de la población. Con todo ello, es necesario realizar un análisis pormenorizado de la relevancia que cobra el Medio Ambiente en la Ley del Suelo actual. ${ }^{29}$

De igual modo, un punto fundamental recogido en la "Exposición de Motivos" en materia ambiental, es la vinculación existente la ciudadanía y el propio "suelo", incluyen los "derechos y deberes de orden socio-económico y medioambiental de toda persona con independencia de cuales sean su actividad o patrimonio": 30

${ }^{28}$ TSLS 2/2008. Exposición de Motivos: "Pero además, del nuevo orden competencial instaurado por el bloque de la constitucionalidad, según ha sido interpretado por la doctrina del Tribunal Constitucional, resulta que a las Comunidades Autónomas les corresponde diseñar y desarrollar sus propias políticas en materia urbanística. Al Estado le corresponde a su vez eiercer ciertas competencias que inciden sobre la materia, pero debiendo evitar condicionarla en lo posible".

${ }^{29}$ Ya en la "Exposición de Motivos" se parte de la idea fundamental de la importancia que cobra la protección de la naturaleza en la propia Constitución Española, señalando que; " $L a$ Constitución de 1978 establece un nuevo marco de referencia para la materia, tanto en lo dogmático como en lo organizativo. La Constitución se ocupa de la regulación de los usos del suelo en su artículo 47, a propósito de la efectividad del derecho a la vivienda y dentro del bloque normativo ambiental formado por sus artículos 45 a 47, de donde cabe inferir aue las diversas competencias concurrentes en la materia deben contribuir de manera leal a la política de utilización racional de los recursos naturales y culturales, en particular el territorio, el suelo y el patrimonio urbano y arquitectónico, que son el soporte, objeto y escenario necesario de aquéllas al servicio de la calidad de vida".

30 "La Constitución de 1978 establece un nuevo marco de referencia para la materia, tanto en lo dogmático como en lo organizativo. La Constitución se ocupa de la regulación de los usos del suelo en su artículo 47, a propósito de la efectividad del derecho a la vivienda $v$ dentro del bloque normativo ambiental formado por sus artículos 45 a 47, de donde cabe inferir que las diversas competencias concurrentes en la materia deben contribuir de manera leal a la política de utilización racional de los recursos naturales $v$ culturales, en particular el territorio, el suelo $v$ el patrimonio urbano $v$ arauitectónico, que son el soporte, obieto $v$ escenario necesario de aquéllas al servicio de la calidad de vida". "Primero, el de la ciudadanía en general en relación con el suelo y la vivienda, que incluve derechos y deberes de orden socio-económico $v$ medioambiental de toda persona con independencia de cuáles sean su actividad o su patrimonio, es decir, en el entendimiento de la ciudadanía como un estatuto de la persona que asegure su disfrute en libertad del medio en el que vive, su 
Uno de los puntos más relevantes, referentes al establecimiento de las bases económicas y medioambientales de la presente Ley la encontramos en el "Título Preliminar". Ya en el artículo 1, en el que se inscribe el objeto de la presente Ley se estipula que "esta Ley regula las condiciones básicas que garantizan la igualdad en el ejercicio de los derechos y en el cumplimiento de los deberes constitucionales relacionados con el suelo en todo el territorio estatal. Asimismo, establece las bases económicas y medioambientales de su régimen jurídico, su valoración y la responsabilidad patrimonial de las Administraciones Públicas en la materia". Y, en el art. 2, se especifica el "principio de desarrollo territorial y urbano sostenible" sobre el que se asientan las políticas regulatorias que favorezcan el uso racional de los recursos naturales: ${ }^{31}$

participación en la organización de dicho medio v su acceso igualitario a las dotaciones, servicios y espacios colectivos que demandan la calidad y cohesión del mismo”.

31 “1. Las políticas públicas relativas a la regulación, ordenación, ocupación, transformación y uso del suelo tienen como fin común la utilización de este recurso conforme al interés general y según el principio de desarrollo sostenible, sin perjuicio de los fines específicos que les atribuyan las Leyes. 2. En virtud del principio de desarrollo sostenible, las políticas a que se refiere el apartado anterior deben propiciar el uso racional de los recursos naturales armonizando los requerimientos de la economía, el empleo, la cohesión social, la igualdad de trato y de oportunidades, la salud y la seguridad de las personas y la protección del medio ambiente, contribuyendo en particular a) La eficacia de las medidas de conservación y mejora de la naturaleza, la flora y la fauna y de la protección del patrimonio cultural y del paisaje. b) La protección, adecuada a su carácter, del medio rural y la preservación de los valores del suelo innecesario o inidóneo para atender las necesidades de transformación urbanística. c) La prevención adecuada de riesgos y peligros para la seguridad y la salud públicas y la eliminación efectiva de las perturbaciones de ambas. d) La prevención y minimización, en la mayor medida posible, de la contaminación del aire, el agua, el suelo y el subsuelo.3. Además de lo dispuesto en el apartado anterior, los poderes públicos propiciarán la consecución de un medio urbano que esté suficientemente dotado, en el que se ocupe el suelo de manera eficiente, y en el que se combinen los usos de forma funcional, garantizando, en particular:a) La movilidad en coste y tiempo razonable, sobre la base de un adecuado equilibrio entre todos los sistemas de transporte, que, no obstante, otorgue preferencia al transporte público y colectivo y potencie los desplazamientos peatonales y en bicicleta. b) La accesibilidad universal, de acuerdo con los requerimientos legales mínimos, de los edificios de uso privado y público, de los espacios de uso público y de los transportes públicos. c) El uso eficiente de los recursos y de la energía, preferentemente de generación propia, así como la introducción de energías renovables. d) La prevención y, en todo caso, la minimización en la mayor medida posible, por aplicación de todos los sistemas y procedimientos legalmente previstos, de los impactos negativos de los residuos urbanos y de la contaminación acústica. La persecución de estos fines se adaptará a las peculiaridades que resulten del modelo territorial adoptado en cada caso por los poderes públicos competentes en materia de ordenación territorial y urbanística. 4. Los poderes públicos promoverán las condiciones para que los derechos y deberes de los ciudadanos establecidos en los artículos siguientes sean reales y efectivos, adoptando las medidas de ordenación territorial y urbanística que procedan para as". 
Desde el punto de vista de la "Exposición de Motivos" y del "Título Preliminar" parece que la Ley supone, en el apartado que se comenta en este trabajo, un avance evidente importante respecto a planteamientos anteriores. ${ }^{32}$ A partir de este momento la práctica totalidad de las referencias lo van a ser a otro tipo de legislación (básicamente la legislación sectorial) y la Ley se convierte, fundamentalmente, en un recordatorio de la necesidad de cumplir toda la legislación ambiental. En el caso del artículo anterior las leyes del ruido estatal y autonómicas y toda la legislación que se refiere a la inmisión de contaminantes,... ${ }^{33}$

Por lo tanto, ya no es cuestión de buenas intenciones, sino de obligaciones específicas que han de cumplir los ciudadanos. Ya sea mediante la prevención de la contaminación como la conservación y preservación de la sostenibilidad ambiental del planeta. Por ello, tal vez este es uno de los artículos de dicha Ley, más relevantes en materia medioambiental.

Posteriormente, ya en el "Título segundo" se recoge uno de los ejes estructurales de la presente Ley, con su correspondiente complejidad y polémica, puesto que aborda la temática de los "criterios básicos de utilización del suelo" -fundamentales para el bueno uso y puesta en práctica de dichas medidas de protección ambiental. En el art. 10 de la presente Ley $^{34}$ se recogen las bases para hacer efectivos los principios,

32 En cuanto al "Título Primero", cabe destacar una cuestión fundamental como son los derechos de los ciudadanos. En el art.4 se expone; "Todos los ciudadanos tienen derecho a:a) Disfrutar de una vivienda digna, adecuada y accesible, concebida con arreglo al principio de diseño para todas las personas, que constituya su domicilio libre de ruido u otras inmisiones contaminantes de cualquier tipo que superen los límites máximos admitidos por la legislación aplicable y en un medio ambiente y un paisaje adecuados".

${ }^{33}$ Por ello, en el art. 5 de la presente Ley se hace alusión, a los deberes de los ciudadanos y a la necesidad del cumplimiento de la normativa ambiental, con independencia de la concienciación ciudadana. "Todos los ciudadanos tienen el deber de :a) Respetar y contribuir a preservar el medio ambiente y el paisaje natural absteniéndose de realizar actuaciones que contaminen el aire, el agua, el suelo y el subsuelo o no permitidas por la legislación en la materia". A su vez, dentro de este "Título Primero", en el art.9 se hace hincapié en la educación ambiental y en la formación de la sociedad en materia ambiental, desde la legislación:"En el suelo que sea rural a los efectos de esta Ley, o esté vacante de edificación, el deber de conservado supone mantener los terrenos y su masa vegetal en condiciones de evitar riesgos de erosión, incendio, inundación, para la seguridad o salud públicas, daño o perjuicio a terceros o al interés general, incluido el ambiental; prevenir la contaminación del suelo, el agua o el aire y las inmisiones contaminantes indebidas en otros bienes y, en su caso, recuperados de ellas; y mantener el establecimiento y funcionamiento de los servicios derivados de los usos y las actividades que se desarrollen en el suelo".

${ }^{34}$ por ello, en dicho artículo se establece que: “c) Atender, en la ordenación que hagan de los usos del suelo, a los principios de accesibilidad universal, de igualdad de trato y de oportunidades entre mujeres y hombres, de movilidad, de eficiencia energética, de garantía de 
derechos y deberes de los ciudadanos. Otro de los ejes fundamentales de la presente Ley en materia medioambiental, lo encontramos en el artículo 15, dedicado a la "Evaluación y seguimiento de la sostenibilidad del desarrollo urbano". ${ }^{35}$ Por último, no por ello menos importante, cabe destacar que en el "Título Tercero", dedicado a valoraciones, se establecen las bases para la puesta en valor del recursos natural "suelo" atendiendo a las distintas tipologías de suelo recogidas en la presente Ley, tal y como vamos a tratar seguidamente, deteniéndonos en la evolución del concepto de suelo

Uno de los puntos principales a la hora de realizar un estudio pormenorizado de la instrumentación económica de la Ley del Suelo y analizar su evolución desde que se aprobó la primera Ley del Suelo de 1956, parte de la descripción del concepto y tipología de suelo, en las distintas legislaciones. De forma concreta en esta Ley, atendiendo a las distintas definiciones existentes de suelo, podríamos afirmar que, desde el punto de vista del urbanismo y la ordenación del territorio, el suelo es el espacio físico sobre el que se asientan edificaciones e infraestructuras, en el que el ser

suministro de agua, de prevención de riesgos naturales y de accidentes graves, de prevención y protección contra la contaminación y limitación de sus consecuencias para la salud o el medio ambiente. 2. Las instalaciones, construcciones y edificaciones habrán de adaptarse, en lo básico, al ambiente en que estuvieran situadas, y a tal efecto, en los lugares de paisaje abierto y natural, sea rural o marítimo, o en las perspectivas que ofrezcan los conjuntos urbanos de características histórico-artísticas, típicos o tradicionales, y en las inmediaciones de las carreteras y caminos de trayecto pintoresco, no se permitirá que la situación, masa, altura de los edificios, muros y cierres, o la instalación de otros elementos, limite el campo visual para contemplar las bellezas naturales, rompa la armonía del paisaje o desfigure la perspectiva propia del mismo". Como afirma el profesor José Fariñas Tojo, "probablemente este artículo ayudará a un mejor control judicial de la discrecionalidad del planeamiento".

35 “1. Los instrumentos de ordenación territorial y urbanística están sometidos a evaluación ambiental de conformidad con lo previsto en la legislación de evaluación de los efectos de determinados planes y programas en el medio ambiente y en este artículo, sin perjuicio de la evaluación de impacto ambiental de los proyectos que se requieran para su ejecución, en su caso. 2. El informe de sostenibilidad ambiental de los instrumentos de ordenación de actuaciones de urbanización deberá incluir un mapa de riesgos naturales del ámbito objeto de ordenación. Los informes a que se refiere este apartado serán determinantes para el contenido de la memoria ambiental, que solo podrá disentir de ellos de forma expresamente motivada. 5 . Las Administraciones competentes en materia de ordenación v eiecución urbanísticas deberán elevar al órgano que corresponda de entre sus órganos colegiados de gobierno que deberá considerar al menos la sostenibilidad ambiental y económica a que se refiere este artículo. Cuestión recogida y analizada en la Ley 9/2006 sobre la evaluación de los efectos de determinados planes y programas sobre el medio ambiente. 6. La legislación sobre ordenación territorial y urbanística establecerá en qué casos el impacto de una actuación de urbanización obliga a eiercer de forma plena la potestad de ordenación del municipio o del ámbito territorial superior en que se integre, por trascender del concreto ámbito de la actuación los efectos significativos que genera la misma en el medio ambiente”. 
humano realiza y desarrolla sus actividades diarias, económicas y sociales. Así pues, la planificación territorial y la regulación urbanística determinan diferentes tipologías de suelo, atendiendo a las distintas iniciativas que se autoricen sobre su uso y disfrute, destacando así el suelo edificable, el suelo industrial, el suelo agrícola,... entre otros. De este modo, el suelo es concebido como un recurso económico importante, sobre todo para el mercado de la vivienda y como determinante del valor de las inversiones. El propio concepto de "Suelo" en la Ley de 1956, presenta como característica más destacada, el hecho de que lo concibe como un recurso natural cuyo valor es meramente económico. diferenciándose y desglosándose diversos problemas que requieren solución, referentes al uso y disfrute del suelo, y que luego se han ido plasmando en las diferentes reformas recogidas en las Leyes posteriores del suelo. ${ }^{36}$

Por otra parte destacar que se presentaban distintas tipologías de suelo. Así, en el titulo segundo, se detallaba la calificación urbanística, en la que se recogía la división que el Plan de Ordenación hacia del suelo de los municipios ${ }^{37}$, y clasificaba el

${ }^{36}$ Tal y como podemos observar en los parágrafos siguientes: a) La retención de terrenos por propietarios que no urbanizan ni edifican ni acceden a enajenar sus terrenos para urbanizar y construir a precios de justa estimación. En la evaluación del suelo que circunda al núcleo urbano prepondera, en efecto, la tendencia de hacer actuar las expectativas de uso o rentas futuras que se incorporan así como valores adicionales al valor actual del fondo, se computa indebidamente la plusvalía que en su momento será el resultado principal de la inversión urbanizadora, sin tener en cuenta que en rigor debe estar ausente del calculo, puesto que cuando, efectivamente llegue a producirse, como consecuencia de las obras en proceso ha de revertir en gran parte en la comunidad, previa aplicación del tratamiento fiscal adecuado. Lo cierto es, sin embargo, que suelen pretenderse precios de especulación, en lugar de precios reales, y en tanto se consiguen o no se hace imposible demora la movilización de la propiedad territorial, es decir se impide la parcelación, venta y edificación de los solares resultantes y la saturación del mercado con ofertas de terrenos a precios razonables. El beneficio que puede obtenerse de transformar el terreno rustico en solar es perfectamente licito, siempre que sea el propietario quien haya costeado la urbanización determinante de aquella mejora y subsiguiente incremento de valor. Pero en cambio, la caprichosa elevación del precio cuando todavía no se ha urbanizado ni desembolsado por los propietarios el coste de las obras correspondientes, implica usurpación de algo no perteneciente al dueño que repercute en perjuicio de la comunidad. b) La imposibilidad de disponer de terrenos amplios para destinarlos a espacios libres en interés del embellecimiento y de las condiciones sanitarias de los núcleos urbanos. c) La falta de distribución equitativa del aumento del valor del suelo, que debe ser afectado, en primer lugar, a amortizar los terrenos necesarios para las vias y espacios libres; en segundo termino, al pago de las obras de urbanización y por ultimo atribuido justamente a los propietarios, de suerte que desaparezcan en lo posible las desigualdades actuales derivadas de conceder la edificación intensiva a unos mientras se niega o limita excesivamente a otros.

${ }^{37}$ Además, según exponía el artículo 71 de la presente Ley, es la que confiera a los derechos y deberes a la propiedad a través de esta división de suelos. Artículo 71: La enajenación de fincas no modificará la situación de su titular en orden a las limitaciones y deberes instituidos por esta Ley o impuestos, en virtud de la misma, por los actos de ejecución de sus preceptos y el adquirente quedará subrogado en el lugar y puesto del anterior propietario en los 
territorio de los municipios en tres tipos de suelo: Urbano, Rústico y Reserva urbana. Respecto del "suelo urbano", también denominado "suelo usado" comprendía todos y cada uno de los terrenos que se incluían en el perímetro del casco, tal y como se recogen en el art. 63 de la LS56.

De igual modo, se delimitaba lo que era el perímetro del casco establecido por el Plan General y como única limitación figuraba el no poder ser edificado si no se cumplían las condiciones de solar, y en tal caso deberá edificar los solares, bajo la carga de expropiación. Y, tal y como se recoge en el art.114 de la LS56, como único deber, la cesión de terrenos para viales, parques y jardines y los costes de la urbanización como pago "justo" a los beneficios obtenidos de ella. El "suelo rústico", por su parte, también denominado "suelo sin usar", estaba definido como el "suelo que sobra", ya que no se podía incluir dentro del "suelo urbano", ni como "reserva urbana", recogiéndose su acepción en el art.65 de la LS56.

Esta es una cuestión que pensamos es de gran importancia, ya que podemos afirmar que esta tipología, de notable interés a la hora de tratar de la Ordenación del Territorio, se recogía en el Plan de Ordenación Urbana, donde se estipulaba que se debía delimitar el mismo perímetro urbano que en las normas sobre suelo urbano, y aunque dentro del suelo rústico se señalaba la necesidad de conservación de determinados suelos agrícolas y forestales, esta protección no suponía una categoría, pretendiéndose, más bien, que las reservas de suelo permitieran la escalonada expansión de los núcleos urbanos y evitara la especulación, que entre otras cosas sustraía prematuramente terrenos a la agricultura.

La tercera tipología era el "suelo de reserva urbana", también denominado "suelo para usar", que comprendía aquellos terrenos que el Plan recogiera para ser urbanizados, pero que no se incluían en el "suelo urbano", es decir, aquellos que se extienden entre el perímetro del casco y el perímetro urbano definido por el Plan General, siendo objeto de los proyectos y planes de extensión, no pudiéndose realizar en ellos un uso distinto al especificado por el Plan General: "Constituirán el suelo de reserva urbana los terrenos comprendidos en un Plan general de ordenación para ser urbanizados y no calificables de suelo urbano según el párrafo 1 del artículo 63".(Art. 64 LS56).

Cabe destacar que no se detalla en este caso al igual que en el anterior ningún tipo de estatuto o deber, a excepción de las obligatorias cesiones. Así, pues, llegados a este punto, podemos afirmar que como hemos podido observar en las distintas calificaciones de suelo y en el texto de dicha Ley, que el medio ambiente, la conservación de los recursos naturales y, especialmente, la protección del suelo, no eran factores que pudiéramos calificar de relevantes. De hecho, no hay especificación alguna al respecto en ninguna parte del mismo.

compromisos que hubiere contraído con las Corporaciones públicas respecto a la urbanización y edificación. 
Igualmente señalar que diferencia de la anterior Ley, el suelo, además de "un recurso económico, es también un "recurso natural, escaso y no renovable". De este modo, todo suelo rural tiene un valor ecológico apreciado, por lo que la liberación y el uso del mismo no debe ser especulativo, ni de acumulación, sino racional, con el fin de atender o satisfacer las necesidades sociales y económicas de la sociedad de manera eficiente. Todo ello, sin olvidar, que también el suelo urbano ya construido tiene un valor ambiental propio, "como creación cultural colectiva que es objeto de una permanente recreación, por lo que sus características deben ser expresión de su naturaleza y su ordenación debe favorecer su rehabilitación y fomentar su uso" (prólogo TRLS 2/2008). En este caso concreto, la Ley diferencia también distintos tipos de suelo. A tenor de la las políticas europeas ${ }^{38}$, orientadas a la protección y conservación del medio ambiente, la nueva Ley considera el suelo como "un recurso natural, escaso y renovable" (prólogo TRLS 2/2008). De igual modo, por primera vez desde la primigenia Ley del Suelo de 1956, se modifica la terminología, dejando de hablar de clases para referirse a situaciones básicas del suelo, que en el artículo 12 del TRLS08 expone hablando de suelo rural y de suelo urbanizado. Se elimina, al menos dentro de la clasificación, aunque no en su esencia, el suelo urbanizable. Se distinguen dos situaciones que únicamente dependen de si el suelo esta transformado o no. El primero de ellos es el "suelo urbanizado", también denominado "suelo para usar", y viene definido en el art. 12. 3, como; "3. Se encuentra en la situación de suelo urbanizado el que, estando legalmente integrado en una malla urbana conformada por una red de viales, dotaciones y parcelas propia del núcleo o asentamiento de población del que forme parte, cumpla alguna de las siguientes condiciones.

A su vez, en el art. 14 del TRLS 2/2008 se estipula que las posibles actuaciones en suelo urbanizado se llevarán a cabo mediante las denominadas "Actuaciones de Transformación Urbanística", si bien, en materia ambiental no se hace referencia ni a derechos ni deberes por parte de los propietarios -tan solo a la conservación, rehabilitación y mejora y cumplimiento de los plazos en la edificación, como se recoge en el art. 9 de la presente Ley-. Pese a todo, sí se hace referencia a la cesión de suelo para viales, zonas verdes y dotaciones, en la que se estipula la cesión de entre un 5 y un $15 \%$ para la administración, el coste y ejecución de la urbanización y la garantía de realojo.

\footnotetext{
38 el crecimiento urbano sigue siendo necesario, pero hoy parece asimismo claro que el urbanismo debe responder a los requerimientos de un desarrollo sostenible, minimizando el impacto de aquel crecimiento y apostando por la regeneración de la ciudad existente. La Unión Europea insiste claramente en ello, por eiemplo en la Estrategia Territorial Europea o en la más reciente Comunicación de la Comisión sobre una Estrategia Temática para el Medio Ambiente Urbano, para lo que propone un modelo de ciudad compacta y advierte de los graves inconvenientes de la urbanización dispersa o desordenada: impacto ambiental. segregación social e ineficiencia económica por los elevados costes energéticos, de construcción y mantenimiento de infraestructuras y de prestación de los servicios públicos.
} 
El segundo de los tipos es el "suelo rural" también denominado "suelo para usar y proteger", y está definido por la Ley en el art. 12.2. ${ }^{39}$

De esta forma, querríamos destacar el hecho de que una de las características esenciales de esta Ley, rompiendo con todas las legislaciones anteriores, es que se expresa claramente la necesidad de reducir el suelo urbanizable. Con anterioridad, sobre todo en la primigenia Ley del Suelo se recogía entre sus líneas la necesidad de incrementar el suelo urbano o urbanizable, con el fin de reducir así su precio. A su vez, una cuestión importante a tener en cuenta es la delegación o cesión por parte del Estado a las Comunidades Autónomas que, a través de sus instrumentos urbanísticos, regulen la transformación de suelo rural en urbanizado. Este es un punto a tener en cuenta, sobre todo a la hora de analizar los Instrumentos Económicos de la Ley del Suelo para la protección y conservación del Medio Ambiente, ya que, como veremos en el epígrafe siguiente, todos los tributos y demás instrumentos económicos son cedidos a las Comunidades Autónomas, a excepción el "precio" $"$.

39 “2. Está en la situación de suelo rural: a) En todo caso, el suelo preservado por la ordenación territorial y urbanística de su transformación mediante la urbanización, que deberá incluir, como mínimo, los terrenos excluidos de dicha transformación por la legislación de protección o policía del dominio público, de la naturaleza o del patrimonio cultural, los que deban quedar sujetos a tal protección conforme a la ordenación territorial y urbanística por los valores en ellos concurrentes, incluso los ecológicos, agrícolas, ganaderos, forestales y paisajísticos, así como aquéllos con riesgos naturales o tecnológicos, incluidos los de inundación o de otros accidentes graves, y cuantos otros prevea la legislación de ordenación territorial o urbanística. b) El suelo para el que los instrumentos de ordenación territorial y urbanística prevean o permitan su paso a la situación de suelo urbanizado, hasta que termine la correspondiente actuación de urbanización, y cualquier otro que no reúna los requisitos a que se refiere el apartado siguiente".

${ }^{40}$ TRLS 2/2008, art.6: La legislación sobre ordenación territorial y urbanística regulara: a) El derecho de iniciativa, en ejercicio de la libre empresa, para la actividad de ejecución de la urbanización cuando esta no deba o no vaya a realizarse por la propia Administración competente. La habilitación a particulares para el desarrollo de esta actividad deberá atribuirse mediante procedimiento con publicidad y concurrencia y con criterios de adjudicación que salvaguarden una adecuada participación de la comunidad en las plusvalías derivadas de las actuaciones urbanísticas, en las condiciones dispuestas por la legislación aplicable, sin perjuicio de las peculiaridades o excepciones que esta prevea a favor de la iniciativa de los propietarios del suelo. Otro de los cambios introducidos, esta vez en la gestión, y dentro de las posibilidades que ofrece la falta de competencias, proviene del intento de dinamizar la gestión privada, ya sea en la urbanización del suelo, en la que contempla la adjudicación de las actuaciones urbanizadoras mediante procedimientos de publicidad, como en la construcción, aunque lo remite directamente a las comunidades autónomas. 


\section{TERRITORIO, SOSTENIBILIDAD Y MEDIO AMBIENTE, EN ESPAÑA: ESPACIOS Y TERRITORIOS RURALES}

Han pasado casi tres décadas desde que en el "Congreso Internacional de Desarrollo Rural" celebrado en Valladolid en junio de 1997. Se constata que el campo y la ciudad son realidades cada vez más próximas e interdependientes. Una muestra de ello es que en los espacios rurales se asiste al retorno de la población que busca una mayor calidad de vida, y en Europa comienza a estar vigente un nuevo concepto: "el urbanismo rural". En este sentido es importante primar criterios generales de ordenación del territorio y de equilibrio poblacional, a través de políticas globales de intervención para el conjunto de los territorios. El objetivo destacable será definir y desarrollar nuevos ámbitos de cooperación y apoyo mutuo para que, en razón de esta interdependencia, mejoren las condiciones de vida de ambos espacios

En este contexto, la Agenda 2000 h.a supuesto un cambio sin precedentes en el proceso de consolidación de la Unión Europea. Con todo, la agricultura, la ganadería y la selvicultura, deberán seguir siendo la espina dorsal de la economía de los espacios rurales. De ahí que la Unión Europea deba mantener su apoyo a la P.A.C., al mismo tiempo que incrementa los fondos para las políticas de mejora de estructuras y desarrollo rural. Es necesario, por tanto, diseñar una estrategia de coordinación de las administraciones y sus políticas de intervención en el medio rural, tanto desde una perspectiva vertical (escala de competencias) como horizontal (escala territorial). Se propone así, la creación de una estructura a modo de Comisión Delegada para Asuntos del Medio Rural, en la que deberían participar las "administraciones" y los representantes de organizaciones de desarrollo y agrarias.

Sin duda, a esta falta de coordinación administrativa se une, asimismo, un vacío legal en materia de ordenación del territorio, que establezca directrices comunes para todo el ámbito nacional, de modo que se puedan unificar criterios. revalidar propuestas de intervención y establecer pautas de trabajo comunes. Todo ello sin olvidar que la política de cohesión económica y social, debe seguir siendo un objetivo prioritario en la Unión Europea. El desarrollo de la agricultura y la ganadería, predominante en muchas áreas rurales con problemas de aislamiento y sostenimiento económico, ha de seguir siendo -por tanto-, un sector de atención preferente en el contexto de la citada cohesión. De ahí la importancia de la futura dotación presupuestaria hacia el medio rural y la aplicación de los fondos estructurales, así como del papel que deberán desempeñar las "Iniciativas Comunitarias de Desarrollo Rural", entre otras. A esto hay que añadir que se ratifican y confirman los postulados o principios en los que se sustenta el desarrollo rural: su condición de proceso endógeno, integrado y globalizador, así como el carácter subsidiario de las administraciones públicas. Su reafirmación en la "Conferencia de Bruselas", obedece a la experiencia contrastada de los LEADER y de los PRODER como instrumentos idóneos en cualquier proceso de desarrollo rural. De hecho para algunos estudiosos nos hemos dirigido hacia un nuevo modelo de desarrollo local en la Unión Europea, cuyas repercusiones en el mundo rural español, serán muy importantes. La iniciativa $L E A D E R$ ha supuesto el primer intento de implantar un nuevo concepto de desarrollo rural. 
A lo que hay que añadir que el programa de desarrollo y diversificación económica de zonas rurales recoge un nuevo enfoque del desarrollo local que implica la potenciación de recursos ociosos, recuperando las oportunidades de creación de actividades productivas existentes que no han sido realmente aprovechadas, que fueron abandonadas y que pueden volver a ser fuente de riqueza. También supone la identificación, estimulación y apoyo de los agentes capaces de llevar a acabo las actividades. Por último, consiste en la movilización de este conjunto de factores en el contexto local, aplicando las estrategias de actuación a un ámbito de dimensiones y características apropiadas (local o comarcal) que permitan esta movilización mediante los procesos de intervención económica y social con ciertas garantías de viabilidad. Junto a esto cobra una notable importancia el medio ambiente, así como las políticas que para su preservación y potenciación se puedan poner en práctica. ${ }^{41}$

El modelo de actuación para solucionar los problemas específicos que afectan a las zonas rurales se basa en la promoción y diversificación de la economía rural, en particular de la actividad agraria, mediante la realización de programas de carácter local implementados por iniciativas públicas y/ó privadas, en articulación con los programas regionales, integrando la participación de la población en su diagnóstico y en las intervenciones requeridas. Para la consecución de estos objetivos se pretenden poner en práctica una serie de medidas con los siguientes objetivos instrumentales:

a) Diversificación de actividades económicas, especialmente de aquéllas que puedan fundamentarse en la utilización de recursos naturales propios.

b) Favorecer el crecimiento del empleo, incentivando la iniciativa privada, especialmente el autoempleo y las empresas asociativas.

e) Asignación de los recursos a los distintos sectores económicos en función de sus potencialidades reales.

d) Incrementar los valores añadidos atribuibles a la calidad de los productos, transformación y comercialización.

e) Asegurar la conservación del espacio natural y de sus recursos, adecuando el uso armonizado de sus funciones productiva, protectora y recreativa.

f) Adecuar los niveles de formación a las necesidades de los procesos de diversificación económica, de reorientación y modernización de los diferentes sectores.

\footnotetext{
${ }^{41}$ Los objetivos que se pretenden alcanzar con la implantación de este programa se basan en el impulso del desarrollo endógeno y sostenido de las zonas rurales de aplicación, fomentando la diversificación de la economía rural. De este modo se pretende conseguir el mantenimiento de la población, frenando la regresión demográfica, elevando las rentas y bienestar social de sus habitantes a niveles más próximos o equivalentes a otras zonas más desarrolladas. La solución más efectiva de los problemas específicos que afectan a las zonas rurales deben de integrar la participación de la población en su diagnóstico y en las intervenciones que se requieran.
} 
g) Impulsar la agricultura por la vía de la revalorización de las producciones agrícolas e integrar otras producciones que satisfagan las necesidades complementarias de renta y trabajo de los agricultores.

h) Promover la creación de nuevas alternativas a la agricultura, en actividades de turismo rural, artesanía y pequeñas industrias, servicios, etc., con el fin de paliar los posibles efectos negativos para la economía rural derivados de la aplicación de la reforma de la PAC.

i) Promocionar y potenciar el conocimiento del patrimonio histórico y artístico.

h) Participación de los agentes económicos y sociales en las iniciativas de desarrollo de las zonas rurales, colaborando con las instituciones públicas en las actuaciones previstas. ${ }^{42}$

A partir de la década de los ochenta del pasado siglo se hizo manifiesta la profunda crisis del sistema rural europeo que obligó a modificar algunos de sus sistemas de protección tradicionales e hicieron patente la necesidad de incorporar otro tipo de estrategias destinadas a las zonas rurales europeas. Como consecuencia de esta nueva situación se iba haciendo evidente que, por un lado, había que actuar selectivamente en el medio rural según los problemas y características de ciertos territorios y, por otro lado, que en algunas regiones desfavorecidas el refuerzo de las estructuras no debía limitarse al sector agrario sino extenderse al conjunto económico regional. De esta manera se va dando una serie de pasos que permiten hablar de una emergente política rural europea. El objetivo de esta política ha sido la revitalización de los territorios rurales a través de la implicación de la población en las estrategias de desarrollo, de la diversificación económica de actividades, de la valorización de los recursos endógenos o del enfoque local en cuanto a la escala de actuación. Esta nueva orientación de la PAC alcanza su máxima expresión en los programas e iniciativas LEADER y PRODER, iniciativas de desarrollo rural que nacen del convencimiento de que éste debe ser integrado, endógeno y local.

En este punto se puede apuntar que son mucho los elementos de coherencia que sustentan el conjunto de las medidas, pero también los interrogantes que puede plantear: interrogantes en torno al modelo de desarrollo propuesto, a la receptividad de las regiones atrasadas para adoptarlo y en relación a la pretendida plurifuncionalidad de los espacios rurales. Con respecto al primer interrogante la idea que hay que destacar es que

\footnotetext{
${ }^{42}$ Como es lógico pensar, la consecución de estos objetivos se pretende alcanzar mediante la puesta en práctica de un número amplio de actividades que se agrupan en siete medidas que poseen un contenido y unas dotaciones presupuestarias asignadas. Medida 1. Pequeñas infraestructuras ligadas a actividades económicas; Medida 2. Valoración del patrimonio rural. Renovación y desarrollo de pueblos; Medida 3. Fomento de las inversiones turísticas en el espacio rural; Medida 4. Creación de pequeñas empresas, actividades de artesanía y servicios; Medida 5. Revalorización del potencial productivo agrario y forestal. Productos de marca e inversiones en favor de productos de calidad locales. Medida 6. Desarrollo de la extensión agraria y forestal y mejora de la formación profesional agrícola y forestal; Medida 7. Asistencia y apoyo técnico al desarrollo rural.
} 
la UE ha hecho un cambio sustancial en la orientación política hacia el desarrollo rural; aunque la prioridad la sigue teniendo la tradicional política de precios y mercados, ya que sigue acaparando el mayor presupuesto. Pero la cuestión fundamental se refiere a la suficiencia de las dotaciones de los fondos estructurales, pese al esfuerzo en su incremento, éste no deja de ser modesto, en relación con la amplitud de los objetivos, además se han privilegiado las líneas de actuación de alcance regional sobre otros ejes (agricultura y el desarrollo rural).

El segundo interrogante a considerar es el propio modelo de desarrollo propuesto y la receptividad de las regiones más atrasadas para adoptarlo. Ante ello, cabe preguntarse ¿hasta que punto las políticas puesta en marcha se adapta a la especificidades de cada espacio? Por un lado, la dificultad reside en la diversidad de medios rurales existentes con marcadas diferencias territoriales y sociales, como ya lo indicaba el documento sobre el "Futuro del Mundo Rural"; por otro lado, hay que considerar que, en modo alguno, las ayudas lleguen por igual a todas las regiones. Con los elementos hasta aquí expuestos cabría considerar la propia dificultad de generar el desarrollo de áreas deprimidas y la incidencia en el mismo del nivel de desarrollo de los ámbitos en que se insertan. Ciertamente, hay que reconocer que existe un alto grado de consenso sobre las causas, la naturaleza y la profundidad de la crisis del mundo rural, y no tanto sobre los mecanismos e instrumentos para hacer operativo un sistema de desarrollo rural. Quizás la conclusión a la que conduce es que se trata de un modelo que puede ser eficaz bajo circunstancias concretas y que no siempre será trasladable a otros contextos temporales, ni espaciales. Es decir, no existe un modelo universal aplicable a todos los lugares, porque ni las situaciones de partida, ni los problemas, ni los recursos o las formas de actuación son equiparables.

Con respecto a la tercera cuestión, ¿hasta que punto la multifuncionalidad se ha conseguido?, hay que apuntar que ha sido clara desde un principio la desviación de los fondos hacia el desarrollo de las actividades turísticas. Ante ello, cabe preguntarse tanto turismo rural ¿es perjudicial o beneficioso? Una de sus principales debilidades es, paradójicamente, la escasez de estudios que ponga en evidencia los aportes que el turismo rural está generando en el desarrollo rural. El turismo no debe sustituir a las actividades agropecuarias tradicionales sino que es una forma de ampliar y diversificar las opciones productivas de las zonas rurales. Habría que valorar hasta qué punto ha propiciado la diversificación productiva, la generación de recursos económicos directos, el mantenimiento de propiedades y la mejora de infraestructuras, además de mejorar las condiciones de vida de las familias directamente implicadas en la actividad, o el progreso y fortalecimiento de otras actividades productivas. Del mismo modo podemos apuntar que en el mundo rural se da actualmente una gran paradoja y es que a pesar de las múltiples políticas, inversiones, iniciativas y programas, éste sigue estando en crisis. En esta línea, Rodríguez Martínez (2008) considera que a pesar de los progresivos e indudables avances de la política europea de desarrollo rural, la ausencia, hasta el momento, de una verdadera política europea de desarrollo rural es algo más que un simple postulado hipotético. 
De hecho, en la actualidad la frontera entre lo rural y lo urbano permite concebir, tanto en términos estadísticos como en términos conceptuales, una franja mixta, que desde los años sesenta del pasado siglo se denominó rururbana, en la que se mezclan ambos estilos de vida y en la que existe un intenso intercambio de relaciones. Recientemente se ha dado en llamar urbanismo rural a este nuevo concepto.

Ese espacio rural de nuevo cuño conceptual alberga hoy nuevas funciones. Sabido es que la plurifuncionalidad ha sido y es consustancial al mundo rural, que la diversidad no es sino la plasmación más evidente de esa trama compleja del territorio campesino y que, desde siempre, la permeabilidad entre la demanda urbana y la oferta rural ha sido el motor de la vida económica y social del campo. Por lo tanto, quizás no sea, en sentido estricto, la aparición de nuevas funciones lo que caracteriza al mundo rural de nuestros días; puede que la novedad radique en el marco en el que se sitúan lo que hoy se ha dado en llamar "nuevas funciones".

${ }^{43}$ En los últimos veinte años, el giro experimentado por una agricultura de signo productivista hacia posiciones más globales de integración territorial y social ha sido bastante acelerado. La reflexión científica, los intentos de articular una compleja normativa comunitaria al respecto y, sobre todo, las evidencias de una sociedad con nuevas sensibilidades confluyen en la misma idea: "la agricultura ya no es la actividad reina, casi exclusiva, del espacio y de la sociedad rural" (Pisani, 1994). Ello no implica ausencia de dificultad en el proceso de cambio, ni el reconocimiento de que las velocidades son muy dispares en el seno de la Unión Europea. Satisfechas sus demandas alimenticias, le pide ahora que descuidar aquéllas desempeñe un papel importante en la conservación del patrimonio natural y cultural, así como una función reguladora de los desequilibrios territoriales y medioambientales. Ya no es suficiente para el mundo rural asegurar las producciones agrarias sino que tiene que cumplir las nuevas funciones que se le han encomendado para garantizar la conservación de los recursos naturales y gestionar ese inmenso espacio rural que, además de ser la reserva de nuestras necesidades alimenticias, por sus valores ambientales, paisajísticos, culturales y sociales, constituye un legado que en manera alguna puede sufrir deterioro. Ello implica una redefinición del propio agricultor que en palabras de Hervieu (1994) representa "un oficio de síntesis en la encrucijada de la producción (teniendo en cuenta los mercados), de la gestión del patrimonio (tierra, agua, paisaje, que son propiedad de nuestros nietos y de la humanidad, tanto como nuestra) y de la ordenación rural del territorio". La condición demográfica de ese mundo rural al que se le pide acomodos sin precedentes quizás no sea lo suficientemente fuerte. El envejecimiento del empresariado, la carencia de un tejido social inserto de manera equilibrada en el territorio, la constatación de un cierto déficit de iniciativa en determinados ámbitos y la necesidad de disminuir la presión en los procesos intensivos de las agriculturas de vanguardia son cuestiones sin solucionar. Toda acción política que no ponga el acento en remediar esta grave situación se convierte, automáticamente, en puro equilibrio y en un producto de diseño, ajeno, en parte, al mundo rural. La reciente evolución de la agricultura da muestras, sin embargo, de que ése es el horizonte. Eso no implica desarmar la función productiva, sino sostenerla en los términos necesarios con el objetivo de acentuar su calidad y fortalecer los sistemas compatibles con la conservación ambiental. Puede que, como señala Massot (1996), una Política Integrada Rural, en el marco del Desarrollo Rural, sea la opción más adecuada para "asumir el conjunto de funcionalidades que hoy tiene atribuidas la actividad agraria". 
Igualmente, destacar que como acabamos de ver, la definición de espacio rural tiene hoy un difícil acomodo bajo una terminología objetiva de cariz numérico. Los organismos estadísticos de cada país, sin embargo, consideran un umbral por debajo del cual los núcleos habitados son considerados asentamientos rurales, en contraposición a los urbanos. En España, el INE cifra este limite en 10.000 habitantes. En otros países de la Unión Europea el umbral puede diferir a tenor de las propias características geográficas, su contexto histórico o los modelos de hábitat.

Por otra parte, respecto del modelo de desarrollo elegido por la Unión Europea -y seguido al pie de la letra por España-, progresivamente diferencia cada vez más dos tipos de explotaciones agrarias. Las explotaciones multisectoriales, propias de las zonas de montaña, de difícil acceso, de escasa capacidad productiva que se sustentan en la diversificación, a través de actividades relacionadas con el cuidado de la naturaleza, la preservación del medio, etc. Y, las explotaciones bien dimensionadas en términos estructurales, tecnológicos y comerciales, cuya organización tendrá un carácter empresarial y competitivo. Los territorios agrarios que sean capaces de obtener buenos rendimientos y eficiencia en la producción y puedan agruparse para entrar en el mercado, deben consolidarse e incrementar sus índices de calidad; siempre sobre el principio de preservación del medio natural. No debemos olvidarnos que la sociedad demanda, cada día más, una agricultura respetuosa con el medioambiente, a través de la puesta en marcha de programas agroambientales que faciliten la compatibilidad de la actividad agraria con la conservación del entorno natural, mediante la puesta en práctica de políticas medioambientales modernas. ${ }^{44}$ En el modelo de desarrollo seguido, para el

\footnotetext{
${ }^{44}$ Será necesario que los agricultores de la Unión Europea se especialicen en prácticas diversas y adapten sus mecanismos y resultados de producción. En este sentido, los agricultores europeos tienen un margen muy favorable de presentación en todos los mercados, a través de los productos de calidad, las denominaciones de origen y marcas de calidad; agricultura ecológica, productos con propiedades curativas (la demanda de los mismos será creciente, como también lo es la sociedad del bienestar y de la preocupación por la salud). Son cada vez más los miembros de la U.E. que programan políticas de ordenación del territorio y orientación productiva, cuyo objetivo es primar las prácticas de explotación respetuosas con el medio ambiente, las regeneradoras de los recursos naturales y la búsqueda de nuevos mercados, entre los que cabe señalar: el apoyo a las energías renovables, la reforestación y la recuperación de espacios degradados. En este sentido, las propuestas de la Agenda 2000 representan un reto para los espacios rurales, que debe resolverse de una forma eficaz. Los ensayos y experiencias que se han llevado a cabo a través de la mencionada "Iniciativa Comunitaria de Desarrollo Rural" (LEADER) y los programas PRODER, deben ser un punto de referencia indispensable. Ambos programas han supuesto una importante contribución en términos de iniciativa empresarial, creación de empleo, proporción entre gasto público e inversión privada, experiencias empresariales innovadoras, e implicación de los agentes económicos y sociales. Confiamos en que una parte significativa de los fondos dirigidos a políticas estructurales se canalicen en estrategias de éstas o similares características, a fin de que puedan consolidarse propuestas de diversificación sólidas y rentables capaces de ser verdaderas alternativas o complemento de las rentas agrarias. Confiamos, asimismo, en la orientación y la reserva de fondos de la futura iniciativa de desarrollo rural a la que la Comisión ha hecho ya referencia en repetidas ocasiones.
} 
sostenimiento de los procesos de desarrollo se estima imprescindible el apoyo a organizaciones y entidades implicadas en el desarrollo rural. La finalidad será, en todo caso, proporcionar a la población rural los necesarios elementos de información, formación y asesoramiento para que puedan llevar a efecto sus propuestas empresariales y sociales. El trabajo que se desarrolle desde estas organizaciones y entidades debe ser interdisciplinar y cooperado entre la población interesada y el personal técnico especializado, a fin de que ninguna propuesta deje de materializarse o fracase por falta de una adecuada previsión. Se estima un efectivo de gran interés para el desarrollo, promover el partenariado institucional y social, favoreciendo la creación de actividades económicas y nuevos empleos. Dichas actividades y empleos irán dirigidos a satisfacer necesidades en materia de servicios a las personas, a las familias y a las comunidades locales, principalmente. ${ }^{45}$

Por otra parte, se hace preciso intensificar los trabajos de diversificación atendiendo a todos los sectores de actividad económica, desde una perspectiva integradora. Aunque los Programas LEADER I y II han sido los catalizadores del turismo rural en España, sin embargo, resta mucho por hacer en otros sectores que, además, son decisivos de cara a lograr unas adecuadas condiciones de vida. En este sentido sería necesario promocionar el sector servicios -imprescindible para fijar la población-, el

La primera innovación que debe presidir todo proceso de desarrollo es la identificación de la población local con el mismo, asumiéndolo como propio, con el convencimiento de que es posible mejorar las condiciones de vida y de trabajo de sus territorios. En segundo lugar, no debemos olvidarnos de que el patrimonio natural y cultural son recursos importantes sobre los que la población elabora propuestas de aprovechamiento, pero no sostienen -por sí mismos- la garantía del carácter endógeno del desarrollo.

${ }^{45}$ El problema no es, por tanto, la catalogación estadística de un espacio como rural, sino la vitalidad del mismo; es decir, si ha tenido la energía suficiente para enriquecerse y cambiar hacia las nuevas posiciones que la sociedad demanda. La cuestión clave es, en suma, constatar si la trama de asentamientos, aún siendo rurales, ha sido capaz de mantener vivo un espacio o, por el contrario, se ha desmoronado, abocando al abandono amplios territorios. Además, la celeridad del proceso de cambio ha supuesto un agravante. Territorios de signo y comportamiento muy diferente se suman en un mosaico desvertebrado en el que se hace necesaria una actuación política específica que debe partir de un conocimiento espacial diferenciado. Es evidente que los problemas del mundo rural - desde la perspectiva que ahora estamos tratando- de la España húmeda del norte y noroeste son bien diferentes de los que aquejan a las Mesetas, Depresiones del Ebro y Guadalquivir, litoral mediterráneo o los de la España insular; y aún dentro de cada una de estas grandes regiones, a nivel comarcal, la realidad es muy diferente. En los ámbitos rurales, las bajas densidades de población (inferiores a $27 \mathrm{hab} / \mathrm{Km}^{2}$ ) se producen fundamentalmente en el interior peninsular - Extremadura, las dos Castillas y Aragón. Sin embargo, bajo estas cifras medias, ya de por sí mínimas, se esconde una realidad aún más preocupante (en cualquiera de estas regiones rurales existen ciudades que concentran población con moderadas densidades frente a un amplio espacio rural). 
comercio, las pequeñas empresas de transformación, los productos de calidad y la apertura de mercados para los productos existentes.

Lo anteriormente expuesto puede concretarse aunando desarrollo y ordenación del territorio. En este sentido, las razones que justifican una dimensión europea de la ordenación del territorio, se ha concretado en la denominada "Perspectiva Europea de Odenación del Territorio" (PEOT), cuyos objetivos y alcance son:

a) Las opciones de acción para la creación de un desarrollo territorial policéntrico y una nueva relación campo-ciudad.

b) Objetivos y opciones de acción relativas a un acceso apropiado a las infraestructuras y al conocimiento.

c) Alternativas de acción en relación con la gestión prudente del patrimonio natural y cultural.

Los procedimientos para la elaboración de la PEOT han sido: la importancia de la participación y debate institucional vertical (distintas administraciones territoriales) y horizontal (administraciones sectoriales). Se busca, no lo olvidemos una "Política de Desarrollo Territorial Integrado", en la que las estructuras administrativas deben velar por la eficacia de las actuaciones de tal manera que sea mínimos los conflictos entre políticas y, en consecuencia máxima rentabilidad de las acciones emprendidas. Por lo que la instauración de una cooperación estrecha entre las políticas sectoriales y las políticas administrativas encargadas del desarrollo territorial (cooperación horizontal) de un lado, y las políticas a escala comunitaria, transnacional, regional y local, del otro (cooperación vertical) redundará en una mayor eficiencia de la utilización de los recursos. La cooperación es la clave de una política de desarrollo territorial integrado. Se trata de dar valor añadido al valor individual de las políticas sectoriales consideradas por separado.

Igualmente, se está discutiendo por la Comisión de la UE la superación de la mencionada PEOT mediante el planteamiento de la ETE (Estrategia Territorial Europea), la cual define el marco de una aplicación integrada de las opciones políticas. Su aprobación supondría un gran avance, pues, su transposición territorial no requiere de la existencia de un organismo especializado pero sí la responsabilidad y la coordinación de un gran número de estructuras político-adminsitrativas encargadas del desarrollo territorial, así como de las planificaciones sectoriales. La política de desarrollo territorial integrado a la escala de la UE debe combinar las opciones políticas a desarrollar por las entidades territoriales de manera que las fronteras administrativas no sean más un obstáculo para el desarrollo.

La ETE recoge tres posibles escalas: la escala comunitaria; la escala transnacional/nacional y la escala regional/local. Desde el punto de vista de la UE, la cooperación a la escala transnacional reviste una importancia particular. Los programas y estrategias transnacionales están destinados a adaptar las políticas sectoriales comunitarias a las necesidades de las diferentes regiones que constituyen la UE. Gracias a ellos las políticas comunitarias pueden armonizarse con las correspondientes 
políticas a nivel nacional, regional y local. Existen diferentes posibilidades de combinar las opciones políticas de la ETE. De ello se deriva una serie de tareas clave destinadas a procurar y mantener una política de desarrollo sostenible, como ejemplo:

- La promoción de la puesta en red de las regiones urbanas. Todas las ciudades y las regiones deben contribuir a la reducción de la tasa de paro, al crecimiento económico y al equilibrio social en la UE. Para ello, es necesario promover las ventajas de las cooperaciones estratégicas y la cooperación entre las regiones urbanas. Se impone un enfoque transnacional de las redes urbanas.

- Mejorar la accesibilidad. Como condición "sine qua non" de un desarrollo policéntrico. Tanto para atender las demandas de mejora de la accesibilidad de las zonas periféricas como para resolver los problemas de congestión de las zonas centrales.

- La creación de eurocorredores. Estos corredores refuerzan la cohesión territorial de la UE y representan un instrumento importante para el desarrollo territorial pues favorecen la cooperación entre las ciudades, mejoran las infraestructuras de los transportes en las regiones periféricas, disminuyen los embotellamientos, ayudan a mejorar la accesibilidad intercontinental, e impulsan el desarrollo regional. El número de corredores potenciales de la UE es elevado. Algunos corredores están ya bien desarrollados. En otras regiones es necesario reforzarlos y conectarlos a los corredores existentes.

- El refuerzo de las ciudades y de las regiones en las fronterizas de la UE. Con políticas bien diseñadas es posible reforzar el papel de las regiones y las ciudades situadas a lo largo de las fronteras exteriores, en el marco de i proceso de ampliación. Por otro lado, esta aproximación fronteriza puede favorecer la profundidad de las relaciones con los piases terceros meridionales, así como de otros centros económicos mundiales de importancia. En consecuencia es prioritario desarrollar las políticas destinadas a las ciudades puerta, a la creación de infraestructuras multimodales para los corredores europeos, impulsar la igualdad del acceso a las infraestructuras de telecomunicación así como al desarrollo de la accesibilidad intercontinental.

- La importancia de los espacios naturales. La creación de una red europea de espacios naturales necesita la coordinación territorial de las diversas políticas comunitarias así como de medidas nacionales. Para alcanzar este objetivo, es importante definir y coordinar a la escala europea mediante la participación activa de la escala regional y local, las interacciones de todos los elementos constituyentes de las redes, tales como las zonas húmedas, los parques nacionales, las islas, las regiones costeras, las lagunas y algunas regiones rurales.

Es evidente que la aplicación de medidas de desarrollo territorial demanda políticas diferentes de las empleadas en los ámbitos políticos, donde la Comunidad detenta una competencia bien definida. Sin embargo, cabe hacer algunas precisiones: a pesar de que la Comunidad no tiene competencias en materia de desarrollo territorial, es indispensable asegurar que las diversas políticas de impacto territorial no 
se entorpecen o no se neutralizan mutuamente. La ETE no debe convertirse en un marco que domine las otras políticas. Su aplicación reposa sobre el principio del voluntarismo. Esto exige ante todo una cooperación, una apertura a los procesos de trabajo consensuados, así que una consulta entre los responsables políticos concernidos y los órganos ejecutivos a escala comunitaria, nacional y regional. El amplio apoyo aportado por los poderes públicos es una de las condiciones claves para la aplicación eficaz de este enfoque de desarrollo territorial.

Como documento europeo, la ETE pone el acento ante todo sobre la escala comunitaria y transnacional. Algunos problemas no pueden ser tratados por uno o dos Estados miembros, requieren la cooperación entre varios Estados para alcanzar las soluciones óptimas. El éxito de una política de desarrollo territorial depende, en este contexto, de una ventaja con respecto a las otras políticas territoriales, que no es otra que las sinergías de las escalas local y regional. Por lo que las estrategias europeas deben contemplar las medidas transnacionales o bien transfronterizas para la aplicación de la ETE para cuya implantación son indispensables las escalas regionales. ${ }^{46}$

${ }^{46}$ Próximamente los Estados que integran la UE van a decidir cómo la normativa nacional podría estar aplicada de manera más eficaz y si es necesario deberían ser promulgadas leyes nacionales complementarias a fin de contribuir a la aplicación de la ETE. La legislación nacional puede claramente reforzar la coordinación transfronteriza de las planificaciones regionales, lo que puede estar apoyado por tratados políticos, declaraciones y protocolos de colaboración, así como por evaluaciones conjuntas de impacto territorial. La aplicación de la ETE o su simple consideración por los diferentes "órganos" europeos puede contribuir a hacer más eficaces las políticas comunitarias. El "Parlamento Europeo", el "Comité de las Regiones" así como el "Comité Económico y Social" han testimoniado, a través de sus posicionamientos, su apoyo a favor de un modelo de desarrollo regional más equilibrado de las ciudades y de las regiones de la UE. La Comisión europea ha constituido un grupo interservicios para analizar las interacciones entre las políticas comunitarias y el desarrollo territorial. Esta labor debe continuar en el futuro, y la Comisión debe asumir la obligación de evaluar de manera sistemática y periódica los impactos territoriales de las políticas comunitarias, tales como la política agrícola común, las políticas de transportes y las redes transeuropeas, la política estructural y la política de i medio ambiente, de la competencia, de investigación y desarrollo a nivel europeo. Esto es igual de recomendable para los órganos de la UE, como para los Estados Miembros, si verdaderamente se busca un desarrollo territorial sostenible. Las reuniones informales de Ministros encargados de la ordenación del territorio y del Comité de Desarrollo Territorial juegan un papel central en la aplicación y la puesta a punto de la ETE. Las instituciones europeas están a favor de una formalización de los órganos de consulta, preservando el principio de subsidiariedad. La mayoría de los Estados Miembros consideran actualmente el carácter informal como el más adecuado; se trata de un terreno político desconocido, donde las experiencias de cooperación en materia de desarrollo territorial se juzgan aún insuficientes, aunque se vislumbra un futuro donde las políticas sean juzgadas por el grado de integración en proyectos comunitarios. La creación de la Unión Económica y Monetaria y la ampliación del comercio internacional refuerzan el conjunto de problemas de desarrollo territorial no sólo para las instituciones de la UE sino también para otros órganos como el Consejo de Europa y la OCDE, para las ONG y grupos económicos, así como para los agentes sociales. Ante este elevado grupo de actores implicados es recomendable fomentar medidas de 
Por otra parte, si descendemos hasta el modelo de desarrollo regional de nuestro país, desde el ámbito rural, cobra gran importancia lo que hoy conocemos como la "Política Ambiental", muy influida por los postulados marcados por "Bruselas". De hecho, en el Tratado de Adhesión de España a la UE no se incluyeron derogaciones temporales que facilitaran la adaptación de la política medioambiental española a la comunitarias. Si partimos de una idea, que la firma del Tratado constituyó más un asunto de consenso entre partidos que una prioridad de la política exterior, junto a la escasa relevancia que se adscribía al tema ecológico, entendemos que se produjera una rápida negociación en la que los aspectos de protección del medio ambiente fueron relegados a segundo término por la delegación española. Esto supone que desde 1986 España se ha enfrentado a un aluvión de directivas medioambientales, que deben ser transpuestas al derecho interno y posteriormente aplicadas, sin que exista un marco previo de actuación en esta política -incluso la legislación sobre control de la contaminación atmosférica, como parte más desarrollada del derecho medioambiental, ha debido adaptarse de forma acelerada a estándares más rígidos y a nuevos conceptos políticos que provienen de la Comisión-. El país, por tanto, se encuentra así obligado a aplicar una política básicamente determinada por las preocupaciones y problemas ecológicos de los estados miembros del centro y norte de Europa, en cuyo desarrollo sólo ha comenzado a participar recientemente.

El lapso transcurrido desde nuestra entrada en la UE, junto a la ausencia de una política medioambiental propia y al escaso número de expertos en estas materias, han hecho difícil que el gobierno español haya influido sustancialmente en la protección del medio ambiente comunitario, e incluso en el nuestro propio. Por ello, la estrategia que se utilizó en el proceso de negociación ha sido fundamentalmente doble: defensiva y reivindicativa. La estrategia defensiva ha insistido en las diferencias económicas y ecológicas del país para conseguir, entre otras cosas, condiciones especiales en la aplicación de las directivas -como muestra el caso referido a grandes centrales térmicasLa reivindicación se ha centrado, por otro lado, en demandar una política medioambiental específica para los países del sur y en exigir la creación de un fondo comunitario dedicado exclusivamente a la protección del medio ambiente (básico para el seguimiento de los modelos de desarrollo seguidos por nuestro país, principalmente, en el mundo rural).

Por otra parte, el distinto nivel de desarrollo económico de los estados miembros constituye, dentro de la estrategia defensiva, la base de una argumentación según la cual los países menos prósperos deben crecer económicamente, hasta llegar al nivel de desarrollo de los del centro y norte de Europa, antes de introducir las costosas medidas medioambientales que propugnan los segundos. Este argumento, que vincula la

cooperación con las colectividades y las instituciones a fin de promover una aplicación práctica y coherente de la ETE a escala internacional (Esteban Moratilla, F. 1999). Otro ámbito en el que se debe realizar un importante empeño por su traducción a empleos de iniciativa privada es el medioambiente, cuyas posibilidades se atisban muy prometedoras. 
protección del medio ambiente a la previa consecución del desarrollo material de los países más ricos de Europa, refleja una visión estática y de corto plazo. Y es que el gobierno español no parece dispuesto a reconocer que el control de la contaminación es un proceso largo de inversiones continuas, que se encarece cuanto más tarde se acomete. La propuesta -tras Kyoto- de permitir un aumento de la contaminación para favorecer el crecimiento económico implica, además, que desde las instancias oficiales no se ha comprendido que "el grado de presión ejercido por la industria sobre el medio ambiente está mucho menos ligado al nivel general de actividad económica que a la naturaleza de los recursos utilizados o los productos manufacturados, la estructura y la localización de la actividad, la tecnología empleada y los métodos de tratamiento de los residuos". El razonamiento español contradice, así, una evidencia que muestra que determinados países han crecido económicamente reduciendo, al mismo tiempo, su contaminación. ${ }^{47}$

Igualmente, no podemos ignorar -tanto en el medio rural como en el urbano- la denominada calidad ambiental y los recursos naturales se presentan como factores fundamentales a la hora de valorar la competitividad territorial, pasando a integrar el denominado capital productivo. Tal es su importancia que, a medio o a largo plazo, la calidad ambiental se muestra como un elemento básico de referencia y, por qué no, de diferencia de la denominada Europa Unida; la protección del Medio Ambiente se convierte de esta manera en uno de los objetivos a alcanzar por las políticas económicas,

${ }^{47}$ Dentro de la estrategia reivindicativa, la primera demanda acerca de la necesidad de elaborar una política medioambiental específica para el sur se relaciona con la denominada ampliación mediterránea de la UE. Ésta supuso la entrada de tres nuevos países (en 1981 Grecia y Portugal, en 1986 España) que compartían problemáticas ecológícas que eran diferentes a las que habían predominado hasta entonces en la Comunidad. Los problemas mediterráneos -que abarcan básicamente la erosión del suelo, la desertización y los incendios forestales- habían sido tradicionalmente relegados a un segundo término en la política comunitaria, y sólo recientemente, tras la crítica unánime de los países del sur hacia la falta de sensibilidad de la UE ante su situación diferencial, han comenzado a tener importancia. La heterogeneidad de las prioridades medioambientales dentro de la Comunidad enfrenta a estos países con los del centro y norte de Europa en temas de asignación de recursos; esto explicaría, por ejemplo, que Alemania fuese la única voz discordante en el debate sobre un proyecto de la Comisión para combatir los incendios en los bosques mediterráneos. La segunda exigencia que, dentro de esta estrategia reivindicativa, enfrenta a España con otros estados miembros ha sido la creación de un fondo específico para la protección del medio ambiente. Este fondo se justificaría por la existencia en los países del sur de hábitats de gran valor ecológico que, ante la exigencia comunitaria de renunciar al desarrollo económico para mantener intacto su entorno, necesitan ayuda de la UE. Asimismo, se ha argumentado que el fondo medioambiental forma parte de una necesaria política de solidaridad, de los estados más prósperos hacia los menos prósperos, y que debería ser independiente de los mecanismos de compensación ya existentes en los fondos estructurales. El interés de España por desvincular la financiación de la protección medioambiental de las políticas estructurales de la Comunidad implica que el medio ambiente no es visto como parte integrante del resto de las políticas y demuestra que el gobierno no ha sabido aprovechar la sinergia de los tres fondos estructurales en acciones medioambientales (Aguilar, S. 1997). 
indicador del progreso encaminado al logro del desarrollo sostenible, con no pocas implicaciones territoriales. España, a pesar de padecer las consecuencias de la deforestación, la erosión, la desertización y la urbanización sólo guiada por el mercado, aún -no sabemos durante cuánto tiempo- disfruta de una notable ventaja sobre la mayor parte de los países comunitarios, por el valor y la diversidad de sus espacios naturales, sus ecosistemas y su calidad del aire (que no así de sus aguas continentales, por fin somos europeos). Desde esta perspectiva, se comprende mejor el que la política medioambiental de los pasados y actuales responsables en materia medioambiental se vaya definiendo, lentamente, a partir de dos "polos" de connotaciones desiguales: la política medioambiental de la Unión Europea -a la que, por imperativos varios, hemos de adaptarnos-, con efectos "a priori" positivos, y, el exceso de competencias "caóticamente" traspasadas a las Comunidades Autónomas cuando el Medio Ambiente no era -quizá, pese a todo, aún no lo sea prioritario en la política gubernamental. Todo ello sin olvidarnos de que la legislación española no incluye una norma general sobre protección del Medio Ambiente, supliéndose con abundante legislación de carácter sectorial o específico, destacando la ausencia de normativa sobre suelos contaminados. De todo lo anterior se deduce la importancia que debe tener para nuestro país la aplicación del "VI Programa de acción de la U.E.", cuyo ámbito abarcó desde legislación o información, hasta economía, pasando por investigación o planificación, y, como es lógico, el "VII P.A.M." que ha entrado en vigor recientemente.

\subsection{LOS CONTEXTOS AMBIENTALES DE UNA AGRICULTURA EN EVOLUCIÓN}

La sociedad demanda, cada vez más una agricultura respetuosa con el medio ambiente, a través de la puesta en marcha de programas agroambientales que faciliten la compatibilidad de la actividad agraria con la conservación del entorno natural. Esta doble aproximación - territorial y estructural- que en los dos epígrafes anteriores se ha utilizado para diagnosticar las claves más significativas que caracterizan hoy al mundo rural, necesita integrarse en una globalidad. El medio ambiente aúna aquella doble dirección y se vuelve marco idóneo para entender que las acciones son solidarias e interferidas. ${ }^{48}$

${ }^{48}$ Esta perspectiva no es novedosa, en manera alguna, pero sí ha adoptado matices diferentes en el seno de la Unión Europea. Desde el Tratado de Roma a los postulados que se han formulado en el documento de debate Agenda 2000 la evolución experimentada ha sido notable. A nivel normativo la influencia de la clave medioambiental en la agricultura ha sido creciente; téngase en cuenta que de los cinco objetivos señalados en el Artículo 39 del Tratado de Roma ninguno hace mención explícita al medioambiente; hay que esperar, por un lado, a 1973 cuando comienzan los Programas de Acción Ambiental y, por otro, a los informes de la Comisión a comienzos de la década de los ochenta (Comisión, 1980; Comisión, 1981; Comisión, 1983a), a la aparición del Libro Verde (Comisión, 1985) y a la concreción de las dos primeras reformas de la PAC (1988 y 1992) para que se consolidara esta preocupación que quedó plasmada en el Tratado de Maastricht..Ya en el Quinto Programa de Acción 
Entre las figuras de protección de ámbito territorial podemos destacar, en primer lugar, el hecho de que hay que hacer referencia a la importancia numérica y territorial de los Espacios Protegidos en España que, necesariamente, hay que conservar y armonizar con el desarrollo rural. Según un informe de la representación española en la OCDE, el $40 \%$ de las superficies especialmente protegidas en la UE corresponde a la red española de Parques Nacionales y Regionales. Ellos articulan una política de protección de paisajes con alguna de las nuevas formas que se exigen a la economía rural en términos de diversificación. El concepto de espacio natural protegido ha cambiado desde que se constituyeron los primeros parques. La conservación museística ha dado paso a una idea de conservación más amplia al comprenderse la interacción hombre-naturaleza. La idea más antigua de actuar sobre espacios aislados ha evolucionado hacia una visión más global de las relaciones entre los seres vivos y su entorno.

Estos espacios son un activo fundamental en cualquier programa o estrategia de desarrollo rural. Las medidas de protección, regulación y promoción deben garantizar un desarrollo sostenible. No obstante, conviene señalar que su gestión debe ser objeto de una regulación específica en la que no se pierda de vista su vinculación con las actividades agrarias ya que, en múltiples ocasiones, las sociedades rurales, practicando unos aprovechamientos tradicionales, nos han legado este patrimonio singular.

A los Parques hay que añadir otros Lugares de Interés Comunitario (LICs) que formarán parte de la futura Red Natura 2000. Sólo las Zonas de Especial Protección de Aves (ZEPAs) españolas, que se integrarán automáticamente en la mencionada red, significan el $10 \%$ del total. Si importante es su participación numérica, mayor es su proporción territorial. España contribuye con un 220 del territorio europeo catalogado como ZEPA.

Este rico patrimonio natural es, y deberá seguir siendo, objeto de otros programas agroambientales alentados desde la reforma de 1988. El primer programa español solicitado tenía por objetivo armonizar la conservación de un humedal de importancia

Medioambiental, subtitulado: "hacia un desarrollo sostenible" (1993-2000) y en las ideas contenidas en el documento Agenda 2000 se marcaban una serie de tendencias muy firmes en la necesaria consideración de la clave ambiental, tanto en los procesos agrícolas productivos, como en el sostenimiento global del mundo rural desde su pluridiversidad y plurifuncionalidad. Una idea fundamental a la hora de abordar esta perspectiva fue la de no separar las acciones puntuales en el territorio, que toman cuerpo en figuras de protección muy diversa, y aquéllas que en amplias extensiones pretenden incardinarse en los propios procesos productivos para hacerlos más compatibles con la conservación del medio. Todos los sectores productivos tienen que implicarse en la preservación del medio ambiente. Dentro de esta filosofía de integración, precisamente sector agrario pasa a ocupar un papel fundamental por lo que será uno de los más afectados por los condicionantes o limitaciones medioambientales que configuran el nuevo enfoque de la política agraria. 
internacional que forma parte de la Lista del Convenio de RA.MSAR. Las Tablas de Daimiel - y la agricultura de regadío que anima la economía rural de La Mancha Occidental. Desde entonces han sido numerosas las acciones llevadas a cabo, sobre todo dentro del marco de las medidas de acompañamiento de la reforma de la PAC de febrero del 2015.

Las Directivas Aves y Hábitats de la UE recogen el imperativo de conservar una larga lista de especies y espacios naturales, recogida en sus anexos, con el fin de garantizar su conservación en un estado aceptable. Estos espacios que, en ocasiones, son las únicas muestras europeas, se encuentran en íntima conexión con los territorios rurales. Una vez más, se impone la obligación de equilibrar protección de la naturaleza y agricultura en el marco del desarrollo rural.

No obstante, la protección de la naturaleza produce externalidades, entendidas éstas como las afecciones en los usos del territorio sobre el que se asientan los espacios protegidos, limitando las posibilidades de producción a causa de la acción de otros agentes económicos sin que ello se refleje en el mercado. Las externalidades significan costes añadidos que aumentan o disminuyen el bienestar, pudiendo ser negativas o positivas para los distintos agentes sociales implicados en la conservación.

Por otra parte, es conocido el diverso patrimonio arquitectónico y arqueológico del campo español que puede amenizar las acciones de turismo rural. Se reconoce el especial interés de los programas LEADER que fomentan estas actividades diversificadoras de la economía rural. En España son múltiples las expresiones de la cultura rural con elevado potencial turístico y expresión individualizable en la política de fomento rural.

Las figuras de protección citadas aquí no son más que un reducido elenco de las muchas existentes. Los efectos positivos de este tipo de acciones parecen probados, pero no puede cifrarse en estas medidas las únicas esperanzas de recomponer y conservar un equilibrio ambiental del todo necesario. Los espacios rurales no sometidos a regulación jurídica precisa en orden a su conservación ambiental resultan claves para no perder esa perspectiva global tan necesaria. Más aún, son éstos los que territorialmente dominan y sobre los que las acciones económicas y productivas deben realizarse con el debido cuidado por la preservación del medio natural. ${ }^{49}$

\footnotetext{
49 En este sentido, no debemos olvidar que una cierta perspectiva histórica que enmarque el reciente cambio acaecido puede ser de interés. Es sabido que, la asignación de funciones diversas a cada uno de los terrazgos que constituyen los ámbitos de actuación de las comunidades rurales siempre se procuró realizar con el conocimiento empírico de las condiciones potenciales de los mismos. Sin caer en el tópico de que los sistemas tradicionales, $\mathrm{su}$ ordenación y costumbres fueron garantía de un aprovechamiento sostenible de los recursos $>$ cosa que evidentemente no siempre fue así, sí es cierto que aquellos sistemas llegaron a "vertebrar" consistentemente el territorio. La condición y consideración ambientales, conscientemente, estaban inmersas en el propio sistema. Los procesos productivos guardaban ritmos acompasados a sus propias características agrológicas y aquellos reductos más relajados de uso, parecían mantener intacta la condición climática. El hombre estaba presente en cada una de las piezas que integraban el espacio rural y no por ello quedó aniquilada la
} 
La perspectiva global, que nunca debe ser obviada en la consideración ambiental de un territorio, nos habla de una ruptura grave entre las comarcas postergadas y aquellas que pudieron avanzar en su transformación estructural y productiva. La interferencia de energía entre unas y otras pudo sufrir daños irreparables al interrumpirse o no guardar la calidad debida por efecto de la pérdida de una relación equilibrada. Ello nos lleva a pensar que determinados "desarrollos medioambientales" aislados y referidos a cada uno de los ámbitos encerrados en sí mismos, bipolarizados y desequilibrados, carecen de sentido hoy en día. Una perspectiva integradora se vuelve imprescindible para actuar con sensatez.

En este marco ambiental al que nos estamos refiriendo merece una especial consideración el paisaje rural. Este, como es bien sabido, es, en parte, el reflejo del pueblo que vive en íntima simbiosis con él; su diversidad, policromía y contraste nos hablan constantemente de la acción humana y del patrimonio natural inserto en el propio paisaje. En los últimos decenios, el abandono se adueñó de buena parte de las áreas deprimidas, en tanto la presión crecía en determinados ámbitos con una mejor condición agrológica y estructural; este proceso implicó para aquéllas la pérdida de una morfología articulada en su cubierta biofísica y del legado paisajístico acumulado a lo largo de varias centurias. Una imagen más homogénea sustituyó a la tradicional policromía; ello ha provocado, en determinados casos, una acumulación de riesgos que, desgraciadamente, se han consumado en no pocas ocasiones (incendios, erosión, etc.). Al mismo tiempo, es preciso reconocer que la recuperación de la biodiversidad

naturaleza. Esta no quiere ser la visión idílica de un mundo sin problemas: las hambrunas se sucedían de tanto en tanto, la excesiva presión ganadera pudo degradar pastizales hasta su extenuación, la deforestación ocasionalmente avanzó inmisericorde ante la necesidad de procurar energía o materias primas, etc. Estos hechos no invalidan, sin embargo, nuestra afirmación anterior. Las exigencias de los nuevos sistemas agrarios, que desde comienzo de los años sesenta se harán cada vez más presentes en nuestras comarcas, afectaron de manera muy importante a aquellas regiones débiles y de precaria condición. La emigración se adueñó de ellas y el abandono tomó sin sentido aquella plurifuncionalidad a la que antes nos referimos. El resultado fue la desvertebración, la pérdida de aquel soporte seguro que sostuvo la vida de cada una de las piezas o terrazgos agrarios. Esta pérdida funcional fue acompañada de una cierta crisis ambiental y de una acumulación de riesgos, desgraciadamente no siempre atajados a tiempo: incendios forestales, erosión, sobreexplotación de acuíferos, desertización, eutrofización, etc. Todo ello debe tender a priorizar la consideración del agricultor desde una nueva perspectiva múltiple de acuerdo a sus funciones económica, social y ambiental. Como se apuntó antes, la tradicional diferenciación entre los espacios rurales y urbanos va siendo superada en un nuevo contexto espacial en el que se consideran los múltiples y complejos vínculos entre ambos dominios, llegando a considerar un espacio mixto y un nuevo concepto llamado "urbanismo rural A los múltiples lazos económicos que tejen una tupida red de intercambios hay que añadir la generalización de nuevos vínculos basados en el ocio. No parece haber desacuerdo en las nuevas misiones atribuidas a la agricultura: "ya no se trata de producir más, sino de producir mejor, de proteger los medios naturales, de mantenerlos y abrirlos a la contemplación y uso por parte de los nuevos actores sociales" (Renard, 1997). 
para amplios terrazgos ha supuesto un signo positivo de indudable valor ambiental. De lo anterior se deduce que la conservación del paisaje rural tiene positivas implicaciones en su funcionalidad ambiental. La "naturalización" de antiguos espacios agrarios no supone necesariamente una mejora desde un punto de vista ecológico; por eso, desligar en el propio oficio campesino los trabajos de conservación y producción no parece una opción adecuada, más bien los dos aspectos deben insertarse en una misma labor. El quehacer productivo debe quedar arraigado en sistemas de aprovechamiento sostenible que potencien, al mismo tiempo, la propia funcionalidad ambiental de ese paisaje rural fuertemente humanizado y haga posible la obtención de los recursos necesarios para la sociedad. ${ }^{50}$

Por todo lo expuesto hasta ahora, parece obvia la conveniencia de redactar una ley de desarrollo rural que tenga un carácter horizontal (como señalan no pocos estudiosos), es decir una fuerte vinculación al territorio, ya que el nuevo modelo de agricultura que se propone desde la UE no puede desligarse de su dimensión ambiental. Los empresarios agrarios deben contemplar, necesariamente, las limitaciones que impone el territorio a su actividad productiva, los condicionamientos del entorno social y, al mismo tiempo, respetar el ambiente bajo un modelo de agricultura sostenible.

Este marco legal deberá tener en cuenta la diferenciación progresiva que de hecho se ha producido entre dos tipos de explotación: las explotaciones multisectoriales, propias de las zonas de montaña y de las áreas desfavorecidas, que tienden a

50 No hacía mucho se preguntaba Mormont sobre el tipo del territorio en el que la población europea desea vivir, haciendo alusión al modelo americano en el que los espacios dedicados a la naturaleza son o deben ser aproximadamente la mitad, repartiéndose el resto entre la ciudad y los terrazgos agrarios de uso intensivo. Sus preguntas vienen al caso: “¿Es el modelo americano el que nos conviene? ¿Se corresponde con nuestra manera de vivir el espacio? ¿No supone un callejón sin salida para las condiciones de vida en la ciudad, incluidas las condiciones ecológicas de vida de las poblaciones urbanas? ¿No recrea la naturaleza a cambio de desarraigar a los hombres de su medio? ¿Es ésta una visión de la naturaleza y del campo que forme parte de nuestra cultura? $\mathrm{O}$ ¿no es nuestra tradición europea, más bien, la de un territorio poblado y una naturaleza humanizada, un espacio rural diferente por sus condiciones naturales, pero diferente también por sus culturas locales y regionales, por sus producciones específicas, sus gustos alimentarios y sus tradiciones, diferentes y ricas, de las múltiples maneras con que las sociedades locales han inventado sistemas de producción, paisajes y formas de sociabilidad que hacen compatible el apego al lugar con el movimiento y el intercambio?" (Mormont, 1994). Por nuestra parte, apoyamos el enfoque del profesor José Antonio Sotelo para quien debemos inclinarnos por una opción que debe integrar los intereses agrarios con los medioambientales haciéndolos compatibles en un mismo territorio. Las regiones euopeas desean mantener su paisaje vivo, económicamente activo y funcionalmente saludable. Esas mismas regiones rurales darán cabida a los nuevos habitantes que, de manera permanente o temporal, se asienten en ellas. Sólo así será posible que, al mismo tiempo, la mentalidad rural acomode sus ritmos a los requerimientos actuales y no se produzcan las terribles disfuncionalidades que terminan por socavar, a veces irremediablemente, los fundamentos de un territorio. 
sustentarse en la diversificación, a través de actividades relacionadas con el cuidado de la naturaleza y su disposición para el uso y disfrute de los visitantes, y las explotaciones bien dimensionadas, con carácter empresarial, que deben consolidarse e incrementar sus índices de competitividad, siempre sobre el principio de preservación del medio natural. Eso no quiere decir que el desarrollo rural deba ser entendido de manera distinta según se trate de comarcas postergadas o bien de áreas con agricultura de vanguardia. La perspectiva global e integradora debe primar y, a la vez, un mismo sustrato soportar acciones coordinadas. No parece recomendable afianzar una dicotomía que, desgraciadamente, ni los últimos decenios llegó a tomar perfiles reales: una agricultura muy productiva orientada a un mercado internacional, poco preocupada por el medio ambiente, y una agricultura de pequeñas estructuras, diversificada, cuyos agricultores sobreviven gracias a apoyos a la renta. Se propone, más bien, buscar un modelo de explotaciones medias, integradas en el mercado y en el territorio, competitivas y respetuosas con el medio. La interferencia entre unas regiones y otras resulta ineludible $\mathrm{y}$, en último caso, los problemas tienen implicaciones múltiples y externas que hacen impensable la ordenación de acciones desconectadas. Por otra parte, en los momentos actuales debemos subrayar la importancia que los problemas ambientales tienen en las regiones deprimidas y en aquellas sujetas a procesos de intensificación acusada tienen connotaciones bien diferentes. Por otra parte, debemos recordar que una de las manifestaciones más claras de la salud ambiental de una determinada comarca o región es el estado de su paisaje. Por último, sostenemos que no es la mejor de las opciones fragmentar el territorio en ámbitos "naturalizados y exentos de labor humana" y otros con fuerte presencia del laboreo y sus correspondientes técnicas productivas más o menos intensivas.

Es sabido que, la asignación de funciones diversas a cada uno de los terrazgos que constituyen los ámbitos de actuación de las comunidades rurales siempre se procuro realizar con el conocimiento empírico de las condiciones potenciales de los mismos. Sin caer en el tópico de que los sistemas tradicionales, su ordenación y costumbres fueron garantía de un aprovechamiento sostenible de los recursos, cosa que evidentemente no siempre fue así, sí es cierto que aquellos sistemas llegaron a "vertebrar" consistentemente el territorio.

La condición y consideración ambientales, conscientemente, estaban inmersas en el propio sistema. Los procesos productivos guardaban ritmos acompasados a sus propias características agrológicas y aquellos reductos más relajados de uso, parecían mantener intacta la condición climática. El hombre estaba presente en cada una de las piezas que integraban el paisaje y no por ello quedó aniquilada la naturaleza, más bien ésta pareció adquirir, si cabe, un mayor esplendor. Ésta no quiere ser la visión idílica de un mundo sin problemas: las hambrunas se sucedían de tanto en tanto, la excesiva presión ganadera pudo degradar pastizales basta su extenuación, la deforestación ocasionalmente avanzó inmisericorde ante la necesidad de procurar energía o materias primas, $\ldots$ 
Las exigencias de los nuevos sistemas agrarios, que desde comienzo de los años sesenta se harán cada vez más presentes en nuestras comarcas, afectaron de manera muy importante a aquellas regiones débiles y de precaria condición. La emigración se adueñó de ellas y el abandono tomó sin sentido aquella plurifuncionalidad a la que antes nos referimos. El resultado fue la desvertebración, la pérdida de aquel soporte seguro que sostuvo la vida de cada una de las piezas o terrazgos agrarios. Esta pérdida funcional fue acompañada de una cierta crisis ambiental y de una acumulación de riesgos, desgraciadamente no siempre atajados a tiempo: incendios forestales, erosión, desertización... Más todavía, la perspectiva global, que nunca puede ser obviada en la consideración ambiental de un territorio, nos habla de una ruptura grave entre las comarcas postergadas y aquellas que pudieron avanzar en su transformación estructural y productiva. La interferencia de energía entre unas y otras pudo sufrir daños irreparables al interrumpirse o no guardar la calidad debida por efectos de la pérdida de una relación equilibrada. Ello nos lleva a pensar que determinados "desarrollos medioambientales" aislados y referidos a cada uno de los ámbitos encerrados en sí mismos, bipolarizados y desequilibrados, carecen de sentido hoy en día. Una perspectiva integradora se vuelve imprescindible para actuar con sensatez.

En este marco ambiental, al que nos estamos refiriendo, merece una especial consideración el paisaje rural. Este, como es bien sabido, es, en parte, el reflejo del pueblo que vive en intima simbiosis con él; su diversidad, policromia y contraste nos hablan constantemente de la acción humana. La homogeneización vivida en los últimos años no puede ser sino un signo de empobrecimiento. Un mundo alejado cada vez más de los ámbitos de concentración demográfica y económica pareció adoptar "tintes naturales" que muchos no dudaron en "descubrir" como reductos de gran valor ambiental; la naturaleza crecida a espaldas del hombre tomó un marcado protagonismo ante la mirada urbana que no dudó en sobrevalorarla. Esta apreciación, sin consistencia científica, nos parece del todo equivocada. Las sobrecargas de uso en las diferentes piezas agranas tuvieron una repercusión infinitamente menor que el desmantelamiento funcional que esas mismas piezas han sufrido en los últimos decenios. El precio pagado por el paisaje es considerable.

La función ambiental está ligada indisolublemente a la conservación del paisaje rural. El agricultor no puede desentenderse del propio dibujo que esculpió sobre el territorio en tanto substraía del mismo aprovechamientos necesarios para su sostén; puede que resulte equivocado insistir en un viraje violento y contra natura del propio oficio campesino al que se le encomienda por parte de algunos una conservación ambiental desligada del quehacer productivo. $\mathrm{Y}$ es que las regiones europeas desean mantener su paisaje vivo, económicamente activo y funcionalmente saludable. Esas mismas regiones rurales darán cabida a los nuevos habitantes que, de manera permanente o temporal, se asienten en ellas. Sólo así será posible que, al mismo tiempo, la mentalidad rural acomode sus ritmos a los requerimientos actuales y no se produzcan las terribles disfuncionalidades que terminan por socavar, a veces irremediablemente, los fundamentos de un territorio. 


\section{CONCLUSIONES}

Tras lo anteriormente expuesto en el presente trabajo podemos llegar a las siguientes conclusiones:

Primera conclusión: El sistema legal resulta altamente contradictorio, ya que objetivo principal es hacer más eficiente el proceso inmobiliario; por ello, la legislación concibe la ciudad como un territorio vacío en el que destacan exclusivamente el ámbito arquitectónico-patrimonial y el ámbito natural, a través de los cuales se asociación los distintos aprovechamientos

Segunda conclusión: Desde el año 1997 hasta la actualidad, en España se ha desarrollado una continua e importante revisión del marco legal en materia de urbanismo lo que ha repercutido de manera directa y, en cierto modo, negativa en la transformación de la ciudad española en la última década del siglo pasado y, más concretamente, en los prolegómenos del siglo XXI. Si bien, en materia medioambiental las constantes modificaciones del planeamiento general inducido por la aplicación de soluciones políticas en materia de urbanismo y ordenación del territorio forzadas por los acontecimientos, no ha servido para contener el creciente despilfarro de recursos territoriales y el encarecimiento de suelo y vivienda a pesar de ser éste el propósito de su promulgación.

Tercera conclusión: la legislación en materia de urbanismo apenas ha contribuido, y mucho menos en los últimos años, a que se lleven a cabo el objetivo principal de reducir la complejidad normativa, sobre todo si tenemos la gran variedad de cambios.

Cuarta conclusión: El precio del suelo en España entre 1990 y 2008 creció a una tasa media anual acumulativa del $14,5 \%$, en tanto que en la etapa entre las dos leyes de suelo estatales, es decir en el periodo 1997-2007, el precio del suelo creció al $25,2 \%$ anual, de lo que se derivó un fuerte aumento de su repercusión en el precio de la vivienda, ya que de representar un $29 \%$ en 1990 pasó a un 46,2\% en 2008 .

Quinta conclusión: La mayor parte de los ingresos de los ayuntamientos proceden del impuesto sobre bienes inmuebles (IBI), un tributo que está ajeno al ciclo económico. Por ello, tras la crisis de la construcción, muchas entidades municipales han subido este impuesto para compensar la caída de la recaudación de los tributos vinculados al ladrillo.

Sexta conclusión: El crecimiento económico está estrechamente relacionado con el desarrollo urbanístico, y es que, es cierto que el crecimiento de los núcleos de población conlleva aspectos positivos, relacionados especialmente con el desarrollo de la economía, pero al mismo tiempo también crea y agrava algunos problemas ambientales. Además, en ocasiones el desarrollo urbanístico de los núcleos de 
población pretende el crecimiento poblacional de los municipios sin tener en cuenta las necesidades de infraestructuras y servicios de los nuevos habitantes.

Séptima conclusión: Tras la aprobación de los Estatutos de Autonomía (Ley Orgánica 9/1982), dos de los principales retos políticos han sido la construcción de la identidad regional y la definición de un modelo territorial propio, que van tomando forma mediante el desarrollo de las competencias que otorga la Constitución Española.

Octava conclusión: El debate sobre la consolidación de nuevas funciones del mundo rural sigue abierto. En los últimos veinte años, el giro experimentado por una agricultura de signo productivista hacia posiciones más globales de integración territorial y social ha sido bastante acelerado. La reflexión científica, los intentos de articular una compleja normativa comunitaria al respecto y, sobre todo, las evidencias de una sociedad con nuevas sensibilidades confluyen en la misma idea: "la agricultura ya no es la actividad reina, casi exclusiva, del espacio y de la sociedad rural".

Novena conclusión: La sociedad se ha vuelto enormemente exigente ante ese mismo mundo rural en crisis Satisfechas sus demandas alimenticias, le pide ahora que sin descuidar aquéllas, le prepare un inmenso espacio de recreo. Ya no es suficiente producir competitivamente, sino administrar, sostener y cuidar debidamente un paisaje rural, unos recursos ambientales y un legado, en suma, que en manera alguna pueden sufrir deterioro.

\section{BIBLIOGRAFÍA}

AA.VV. (1994). Medio rural español. EL. Cultura, paisaje y naturaleza (2 tomos), MAPA, Salamanca, $1250 \mathrm{p}$.

AA.VV. (1992). El futuro del mundo rural. MAPA, $150 \mathrm{p}$.

AAVV (2006) Cambios de ocupación del suelo en España. Implicaciones para la Sostenibilidad.Observatorio de la Sostenibilidad de España

AA.VV. (1972). Regionalización y desarrollo., CNRS., 419 págs.

AA.VV. (2007). Abastecimiento de agua en España., Madrid., Hispagua.

AAVV (2008) Agua y sostenibilidad: Funcionalidad de las cuencas. Observatorio de la Sostenibilidad de España

AA.VV. (2011). Desarrollo sostenible en España en el final del siglo XX. EUMED. Madrid.,

AAVV (2013). Legislación Urbanística Estatal y Autonómica. ST, Sociedad de Tasación.

BOIX, R. (2006). Las áreas metropolitanas en España. En: Desarrollo de regiones y Eurorregiones. El desafío del cambio rural. XXIII Reunión de Estudios Regionales. Asociación Galega de Ciencia Rexional.

BOSQUE MAUREL, J. (2000). "La Geografía y la ciudad (Cuatro estudios): "Globalización y nacionalismo: una reflexión" (págs. 153-169), "Revolución 
urbana, crecimiento demográfico y nuevas tecnologías" (págs. 167-181); "La ciudad mediterránea" (págs. 183-193), y "La ciudad de Granada" (págs. 195-229), en G. R. MEJIA PAVOY y F. ZAMBRANO PANTOJA. (Edits.), La ciudad y las ciencias sociales. Ensayos y aproximaciones. Santa Fe de Bogota, CEJA, 229 págs.

BRUNDTLAND, G. R. (1988). Our Common Future. The Report of the Wold Commission on Environment and Development. Oxford University Press..

CAPEL, H. (1975). La definición de lo urbano. Estudios Geográficos, 138 139, p. 265-301.

CAPEL, H. (2003). Una mirada histórica sobre los estudios de redes de ciudades y sistemas urbanos. GeoTrópico, 1, p. 30-65.

CASAS TORRES, J. M. (1982). Población, desarrollo y calidad de vida. Madrid. Rialp. 338 págs.

DE COS, O. (2004). Valoración del método de densidades focales (Kernel) para la identificación de los patrones espaciales de crecimiento de la población en España. Geofocus, 4, p. 136-165.

DE COS, O. (2007). SIG y evaluación multicriterio: propuesta metodológica para cuantificar el grado de metropolización en el territorio. Mapping. Marzo, 2007.

DE COS, O.; REQUES, P. y MARAÑÓN, M. (2011). Ruralurban gradient and sustainability in Spain: a municipal-scale approach. The Sustainable World. C.A. Brebbia. Wessex Institute Technology Press. P. 101-108.

ESTEVAN, A. y SANZ, A. (1999). Hacia la reconversión ecológica del transporte en España., Madrid. Libros La Catarata.

EMBID IRUJO A. (2007) Conflictos jurídicos en la gestión y uso del agua. Consejo General del Poder Judicial, Madrid.

ESTRATEGIA DE MEDIO AMBIENTE URBANO (2010)

ESTRATEGIA DE DESARROLLO SOSTENIBLE (2007). Ministerio de la Presidencia. M-54376-2007

ESTRATEGIA TEMÁTICA EUROPEA DE MEDIO AMBIENTE URBANO (2006) E

FARIÑA, J. y NAREDO, J.M. (2010). Libro Blanco de la sosteniblidad en el Planeamiento Urbanístico Español. Ministerio de la vivienda.

FARINOS, J. y ROMERO, J. (2007). El gobierno del desarrollo territorial sostenible. A modo de presentación. En Farinos, J. y Romero, J. (coord). Territorialidad y buen gobierno para el desarrollo sostenible: nuevos principios y nuevas políticas en el espacio europeo.

FERIA TORIBIO, J. M. (2004). Problemas de definición de las áreas metropolitanas en España. Boletín de la AGE, 38, p. 85-99.

FERIA TORIBIO, J.M. y ALBERTO PUEBLAS, J.M. (coords.) (2010): La ciudad metropolitana en España: procesos urbanos en los inicios del siglo XXI. Pamplona. Cívitas. $442 \mathrm{p}$.

FONT, A. (2004). Un nuevo planeamiento para una nueva territorialidad. Ciudad y Territorio: Estudios Territoriales. Pp. 141-142: 561-56 
GARCÍA LÓPEZ, M.A. (2007). Estructura Espacial del Empleo y Economías de Aglomeración: El caso de la Instrustria de la Región Metropolitana de Barcelona. Architecture, City \& Environment, $n^{\circ}$ 4. pp. 519-553

GLASS, R. (1964). Aspects of Change, Londres, Centre for Urban Studies, MacGibbon and Kee.

HARVEY, D (1985).Consciousness and the Urban Experience: Studies in the History and Theory of Capitalist Urbanization, Oxford, Basil Blackwell.

HARVEY, D (1985).The Urbanization of Capital: Studies in the History and Theory of Capitalist Urbanization, Oxford, Basil Blackwell.

HARVEY, D (2011). Espacios del capital. Hacia una geografía crítica., Madrid., Edt. AKAL., pp.445.

HERVIEU, B., 1994. Les champs du futur Editions Julliard (publicado en castellano en 1997 por el MAPA en Serie Estudios no 118, bajo el título "Los campos del futuro").

HERVIEU, B., 1996. Les agriculteurs, PUF, 127 p.

INSTITUTO VALENCIANO DE INVESTIGACIONES ECONÓMICAS (2010). $E l$ stock de capital en viviendas en España y su distribución territorial (1990-2007).

JUARISTI, J. (1995). El sistema urbano español y sus relaciones con el sistema urbano europeo. En: Las ciudades españolas a finales del siglo XX: I Coloquio de Geografía Urbana. Cuenca: Universidad de Castilla-La Mancha - Madrid: AGE, p. 17-27.

LÓPEZ VERA, F. (2009). La gestión del Agua en España.

MARMOLEJO, C; AGUIRRE, C. y RUIZ, M. (2010). ¿Hacia un sistema de metrópolis españolas policéntricas?: caracterización de su estructura metropolitana, en VI Congreso Ciudad y Territorio Virtual, UABC, Mexicali (Méjico).

MASSOT, A. (1996). Una política agroalimentaria y rural para una Unión Europea del Bienestar. Revista Española de Economía Agraria, n 176-177, 2-3/1996, Pp. 99-143.

MASSOT, A. (1997). ¿Política Rural Integrada o desintegración de la PAC?. Revista Agropecuaria n ${ }^{\circ} 783$, octubre de 1997, pp.776-775.

MÉNDEZ, R. y CARAVACA, I. (1993). Procesos de reestructuración industrial en las aglomeraciones metropolitanas españolas. Madrid: MOPT, Dirección General de Política Territorial y Urbanismo.

MINISTERIO DE MEDIO AMBIENTE. (2001). Evaluación Ambiental Estratégica del Plan Hidrológico Nacional. Ministerio de Medio Ambiente. Madrid.

MINISTERIO DE VIVIENDA (2006). Atlas estadístico de las áreas urbanas en España. Madrid.

MINISTERIO DE MEDIO AMBIENTE (2006). Estrategia de medio ambiente urbano.

MAROIS, C. (1996). Le couple ville-campagne: une cohabitation changeante. L 'action nationale, 2: 201-207.

MORENO, A. (1991). Modelización cartográfica de densidades mediante estimadores Kernel, Treballs de la Societat Catalana de Geografia, 6, 30, p. 155170. 
MORMONT, M. (1994). La agricultura en el espacio rural europeo, Agricultura y Sociedad n ${ }^{\circ}$ 71, Abril-Junio 1994, Pp. 1 7-49.

NAREDO, J.M (Ed.) (1997): La economía del agua en España. Fundación Argentaria. Visor Distribuciones, Madrid.

NEL.LO, O. (2004). ¿Cambio de siglo, cambio de ciclo? Las grandes ciudades españolas en el umbral del S.XXI. Ciudad y Territorio. Estudios Territoriales, XXXVI (141-142), p. 523-542.

OBSERVATORIO DE LA SOSTENIBILIDAD EN ESPAÑA (2006). Cambios de Ocupación del Suelo en España. Implicaciones para la sostenibilidad.

PARRA, F. (2010). Legislación. Ciudad y territorio: Estudios territoriales. No 163.

PAZ, M.A. (1998). Economía mundial. Madrid, Edt. Pirámide, 605 págs.

PINTADO MANZANEQUE, J. (2004): Guía de Buenas Prácticas de proyectos de urbanización sostenible. Ciudad Real. Federación de Municipios y Provincias de Castilla La Mancha, Colegio de Ingenieros de Caminos, Canales y Puertos, y Junta de Comunidades de Castilla La Mancha.

PLAZA TABASCO, J. J. (2003): “¿Es la LOTAU una ley de ordenación del territorio o una ley del suelo?". Formas de Arquitectura y Arte, no 2, 8-13.

PLAZA TABASCO, J., MARTÍNEZ SÁNCHEZ-MATEOS, H.S. y GOSÁLVEZ REY, R.U. (2011): "La ordenación del territorio en Castilla La Mancha: estado de la cuestión y estudios de casos". Cuadernos Geográficos, nº47, 493-522.

PNUMA. 2000. Perspectivas del Medio Ambiente Mundial.

PNUMA. 2004. Contribuciones al medio ambiente.

PRIETO, F. et alii (2011).Tendencias recientes de evolución del territorio en España (1987-2005): causas y efectos sobre la sostenibilidad. Ciudad y Territorio: Estudios territoriales.

PRECEDO, A. (1986). Las modificaciones del sistema urbano español en la transición postindustrial. Estudios Territoriales, 20, p. 121-138.

REQUES, P. y RODRÍGUEZ, V. (1998). Atlas de la población española: análisis de base municipal. Santander: S. Publicaciones Universidad de Cantabria y CSIC.

ROCA, J., BURNS, M. y MOIX, M. (2004). Las áreas metropolitanas españolas. Evolución 1991-2001. Barcelona: Centre de Política de Sòl i Valoracions, Universitat Politécnica de Catalunya.

ROCA, J. (2003). “La delimitación de la ciudad, ¿una cuestión posible?”. Ciudad y Territorio. Estudios Territoriales, XXXV. pp. 17-36

RODRÍGUEZ LÓPEZ, J. (2006) El suelo y el auge inmobiliario. El PAIS, 22 de julio

RODRÍGUEZ, V. y REQUES, P. (2000). La (re)distribución espacial de la población: los cambios a lo largo del presente siglo. A Distancia, Vol. 18, 1, pp. 155-161.

RODRÍGUEZ, J. (2010). El mercado de la vivienda. El país, 14 de febrero.

SANTOS, J. M. (2000). La formación y desarrollo de las áreas metropolitanas. A Distancia, Vol. 18, 1, p. 162-170.

SERRA, J. (2002). Grandes aglomeraciones metropolitanas europeas. Un ensayo de delimitación. Papers, 37. 
SÉRVUlo GONZÁlEZ, J. (2012). Ciudades Ahogadas por la deuda. El País.

SMITH, N. (2012). La nueva frontera urbana. Ciudad revanchista y gentrificación., Madrid., CC. 382 págs.

SOTELO NAVALPOTRO, J.A. (2006). Bases territoriales de la planificación integral. El estudio de caso: La Cuenca del Tajo. Madrid. Revista de Arte, Geografía e Historia, $n^{\circ}$ 8. pp. 359 - 396.

SOTELO NAVALPOTRO, J.A. (2001). Estudiar la Región. Infodal, pp.285.

SOTELO NAVALPOTRO, J.A. (2001). Environmental Europe. Oxford University Press, pp. 195

SOTElO NAVAlpotro, J. A. (2000a). Regional Development Models, Oxford University Press.

SOTElO NAVAlpotRO, J. A. (2000b). Medio Ambiente y Desarrollo en España en los prolegómenos del siglo XXI: Las Políticas Medioambientales de la UE, Observatorio Medioambiental, n.0 3, pp. 34 1-397.

SOTELO NAVALPOTRO, J.A. (1999). Modelos de Organización y Desarrollo Regional. Oxford University Press

SOTELO NAVALPOTRO, J.A. (1998). Medio Ambiente y Desarrollo en la España de los noventa: la problemática regional de los residuos tóxicos y peligrosos., Anales de Geografía de la UCM., no 18., pp. 257/280.

TAMAYO-ACOSTA, J.J. (1999). El cristianismo en tiempos de globalización, El País, 4 de enero, pág. 12.

TEXTO REFUNDIDO DE LA LEY DE HACIENDAS LOCALES, Real Decreto $2 / 2004$, de 5 de marzo

TEXTO REFUNDIDO DE LA LEY DE CONTRATOS DEL SECTOR PÚBLICO, Real Decreto Legislativo 3/2011.

TEXTO REFUNDIDO DE LA LEY DEL SUELO, 2/2008

URIEL JIMÉNEZ E. (dir.) (2009): El stock de capital en viviendas en España y su distribución territorial 1990-2007. Fundación BBVA. (IVIE, 2010).

VINUESA, J. (1975). Sobre el concepto de área metropolitana. Estudios Geográficos, 140-141. p. 1143-1156.

VALENZUELA, L.M. (2011). Observatorios territoriales y urbanos en Europa, ¿entidades pasivas o instrumentos operativos para la planificación? Ciudad y territorio: Estudios territoriales. $\mathrm{N}^{\mathrm{o}} 163$.

VALENZUELA, M (coord.). El impacto del modelo autonómico en las ciudades españolas. Una aproximación interdisciplinar. Madrid. Servicio de Publicaciones de la Universidad Autónoma de Madrid. Colección Estudios. pp. 762. 